\title{
The Paleozoic Mount Carlton Deposit, Bowen Basin, Northeast Australia: Shallow High-Sulfidation Epithermal Au-Ag-Cu Mineralization Formed During Rifting
}

\author{
Fredrik Sahlström, ${ }^{1, \dagger}$ Paul Dirks, ${ }^{1}$ Zhaoshan Chang, ${ }^{1}$ Antonio Arribas, $, 1,2,{ }^{\circ}$ Isaac Corral, ${ }^{1}$ \\ Matthew Obiri-Yeboah, ${ }^{3}$ and Chris Hall ${ }^{2}$ \\ ${ }^{1}$ Economic Geology Research Centre (EGRU), College of Science and Engineering, James Cook University, \\ Townsville, Queensland 4811, Australia \\ ${ }^{2}$ Department of Earth and Environmental Sciences, University of Michigan, Ann Arbor, Michigan 48109-1005, USA \\ ${ }^{3}$ Evolution Mining, Mt. Carlton Operations, Garbutt, Queensland 4814, Australia
}

\begin{abstract}
Mount Carlton is a Paleozoic high-sulfidation epithermal deposit located in the northern segment of the Bowen Basin, northeast Queensland, Australia. The deposit is hosted in Early Permian volcanic and sedimentary rocks, and an open-pit mining operation includes the Au-rich V2 pit in the northeast and the Ag-rich A39 pit in the southwest. Mineralization at Mt. Carlton occurred during active rifting, partly contemporaneously with the deposition of volcanic sediments in localized half-graben and graben basins. Steep normal faults and fracture networks related to the rifting acted as fluid conduits and localized cores of silicic alteration. The silicic cores transition outward to zones of quartz-alunite alteration, which are, in turn, enveloped by a zone of quartz-dickite-kaolinite alteration. Epithermal mineralization at Mt. Carlton developed in three stages: Cu-Au-Ag mineralization dominated by enargite was overprinted by $\mathrm{Zn}-\mathrm{Pb}-\mathrm{Au}-\mathrm{Ag}$ mineralization dominated by sphalerite, which, in turn, was overprinted by $\mathrm{Cu}-\mathrm{Au}-\mathrm{Ag}$ mineralization dominated by tennantite. Proximal Au-Cu mineralization in the V2 pit occurs in networks of steep faults associated with veins and hydrothermal breccias within a massive rhyodacite porphyry. Three distinct ore zones (Eastern, Western, and Link) are aligned, en echelon, along a broadly E trending corridor. The Western ore zone continues along $600-\mathrm{m}$ strike length to the southwest into the A39 pit, and it shows a metal zonation, from proximal to distal, of $\mathrm{Au}-\mathrm{Cu} \rightarrow \mathrm{Cu}-\mathrm{Zn}-\mathrm{Pb}-\mathrm{Ag} \rightarrow \mathrm{Ag}-\mathrm{Pb}-(\mathrm{Cu}) \rightarrow$ Ag. Distal Ag mineralization in the A39 pit is concentrated in a volcanolacustrine sedimentary sequence that overlies the rhyodacite porphyry. It occurs in a stratabound position oriented parallel to primary sedimentary layering and locally exhibits synsedimentary ore textures. Such textures are interpreted to have formed as mineralizing fluids discharged into what most likely were lakes developed within localized rift basins, at the same time that the volcanolacustrine sediments were deposited. At depth, equivalent ore textures were produced within open spaces in the structural roots of the rift basins. ${ }^{40} \mathrm{Ar} /{ }^{39} \mathrm{Ar}$ dating of hydrothermal alunite yielded an age range of $284 \pm 7$ to $277 \pm 7 \mathrm{Ma}$, which links the formation of the Mt. Carlton deposit to the Early Permian back-arc rifting stage in the Bowen Basin. Prolonged extension provided rapid burial of the deposit beneath a postmineralization, volcanosedimentary cover, which was essential for the exceptional preservation of Mt. Carlton. The same extension caused displacement of the rock pile along a series of shallowly dipping detachment faults and segmentation and rotation of the ore zones across steeply dipping normal faults. This deformation would have displaced any underlying porphyry mineralization relative to the current location of Mt. Carlton.
\end{abstract}

\section{Introduction}

High-sulfidation epithermal deposits are typically found in andesitic to dacitic volcanic arcs subjected to variable regional stress regimes, ranging from mildly extensional to compressional (Sillitoe, 1993, 2010; Cooke and Simmons, 2000; Tosdal and Richards, 2001; Sillitoe and Hedenquist, 2003). These deposits are believed to form in magmatic-hydrothermal environments similar to those that occur beneath modern volcanic fumaroles and crater lakes (Hedenquist et al., 1993). They are mined predominantly for their Au content, while other metals (chiefly $\mathrm{Ag}$ and $\mathrm{Cu}$ ) may be economically important in individual deposits (Arribas, 1995a; Singer, 1995). Mineralization in high-sulfidation deposits may occur in contact with or only a few meters beneath the paleosurface, but,

\footnotetext{
† Corresponding author: e-mail, fredrik.sahlstrom@my.jcu.edu.au

${ }^{*}$ Current address: International Center for Research and Education on Mineral and Energy Resources (ICREMER), Akita University, Akita 0108502, Japan.
}

more commonly, it is separated from the paleosurface by up to several hundred meters (Sillitoe, 2015). Mineralization styles include hydrothermal breccias, veins, stockworks, and disseminations or replacements (Arribas, 1995a). The highgrade ore commonly occurs within cores of silicic alteration, locally exhibiting a vuggy texture, which reflect the leaching effects of highly acidic ( $\mathrm{pH} \approx 1$; Stoffregen, 1987) magmatic vapor condensates injected into the epithermal environment. The silicic cores, which typically are no more than a few tens of meters wide, have halos of advanced argillic minerals (e.g., alunite, dickite, kaolinite, pyrophyllite, diaspore, and pyrite) that may have areal extents up to several square kilometers (Steven and Ratté, 1960; Stoffregen, 1987; Arribas, 1995a; Sillitoe, 1995). High-sulfidation epithermal deposits typically have structurally controlled feeders (e.g., local subvertical faults and fractures), with silicic-advanced argillic alteration possibly forming horizontal to subhorizontal lithocaps along specific horizons, such as unconformities and permeable rock layers (Arribas, 1995a; Sillitoe, 1999, 2010; Hedenquist et al., 
2000; Chang et al., 2011). These deposits and their associated lithocaps can be considered as the top parts of larger intrusion-driven hydrothermal mineralizing systems, centered on porphyry intrusions that may be enriched in $\mathrm{Cu}, \mathrm{Au}$, and/or Mo (Arribas et al., 1995b; Hedenquist et al., 1998; Sillitoe, 2010; Chang et al., 2011).

Queensland, Australia, has an abundance of mineral deposits related to Carboniferous and Permian magmatism, which formed inboard of an active continental margin (Henderson, 1980; Champion and Mackenzie, 1994; Blevin et al., 1996; Bain and Draper, 1997; Champion and Bultitude, 2013). Clusters of porphyry and epithermal $\mathrm{Cu}-\mathrm{Au}$ deposits and prospects occur in the northern segment of the Bowen Basin in northeast Queensland (Fig. 1). Mineralization in the northern Bowen Basin is predominantly hosted in Early Permian volcanic rocks that were deposited within a back-arc rift environment (Donchak et al., 2013). The most significant, and the only deposit currently in production, is the Mt. Carlton high-sulfidation deposit. Mt. Carlton was discovered in 2006 and has estimated resources (indicated + inferred) of 10.42 million tonnes (Mt) averaging $2.92 \mathrm{~g} / \mathrm{t} \mathrm{Au}, 30.60 \mathrm{~g} / \mathrm{t} \mathrm{Ag}$, and $0.47 \% \mathrm{Cu}$, containing $\sim \mathrm{Moz} \mathrm{Au}$ (as of December 2016; M. Obiri-Yeboah, pers. commun., 2017). With respect to its average $\mathrm{Au}$ grade, Mt. Carlton is comparable to medium-grade and unoxidized high-sulfidation deposits such as Lepanto, Rodalquilar, Chelopech, Chinkuashih, Pierina, and Pueblo Viejo (Fig. 2). Mt. Carlton differs from most of these deposits in that it is mined using open-pit methods. This includes the larger and Au-rich V2 pit in the northeast and the smaller and Ag-rich A39 pit in the southwest (Fig. 3).

Due to high erosion rates in most volcanic arcs, the preservation potential of high-sulfidation deposits in older terranes is generally poor (e.g., Kesler and Wilkinson, 2006). Mt. Carlton is, therefore, of particular interest as it is one of only few known economic, pre-Neogene, high-sulfidation deposits in the world. In this study, we document the geologic setting, hydrothermal alteration, mineralization, mineral chemistry, and ${ }^{40} \mathrm{Ar} /{ }^{39} \mathrm{Ar}$ geochronology of the Mt. Carlton deposit. This study contributes to the understanding of the characteristics, formation, preservation, and tectonic modification of shallow high-sulfidation deposits in extensional settings. This information can, in turn, be useful when exploring for epithermal and porphyry deposits in similar geologic terranes elsewhere.

\section{Regional Geology}

The Bowen Basin is an NNW-trending, elongate, and asymmetrical sedimentary basin covering an area of $~ 200,000$ $\mathrm{km}^{2}$ in eastern Queensland. It formed as part of the New England Orogen during the Early Permian to Middle Triassic and is the northern part of a larger basin system that also includes the Gunnedah and Sydney basins in New South Wales (Donchak et al., 2013). The Bowen Basin shows evidence of a complex and polyphase tectonic evolution, divided into back-arc extension, thermal relaxation, and foreland basin stages. The Bowen Basin was initiated in the Early Permian by extension of the back-arc continental crust inland of the Connors arc, causing rifting (Esterle et al., 2002; Korsch et al., 2009). This produced a series of isolated NNW-trending graben and half-graben basins, which were infilled by volcanic and sedimentary rocks (Murray, 1990;
Hutton et al., 1999; Esterle et al., 2002; Korsch et al., 2009). The Lizzie Creek Volcanic Group was deposited during this time and comprises calc-alkaline, andesitic to rhyolitic volcanic rocks, and minor terrestrial sediments, which host most of the mineralization in the northern Bowen Basin (Paine et al., 1974; I. Corral, unpub. data, 2018). The back-arc rifting stage was followed by a period of thermal relaxation and subsidence in the Middle Permian, which led to flooding of the Bowen Basin and deposition of marine and coastal plain sedimentary units (Malone et al., 1969; Esterle et al., 2002; Allen and Fielding, 2007; Korsch and Totterdell, 2009). The thermal relaxation stage was abruptly terminated in the Late Permian, due to the onset of the $\sim 265$ to 235 Ma HunterBowen Orogeny (Donchak et al., 2013). This led to foreland loading, tectonic inversion, and development of a foreland basin. Terrestrial sediments deposited in the foreland basin make up the bulk of the Bowen Basin infill, and they contain several economically important coal deposits (Fielding et al., 1990; Fergusson, 1991; Holcombe et al., 1997; Esterle et al., 2002).

\section{Geology of the Mt. Carlton Deposit}

\section{Stratigraphy}

The basement unit at Mt. Carlton is a granite belonging to the Urannah batholith ( 302-296 Ma; I. Corral, unpub. data, 2018). The batholith contains several high-temperature, I-type granites (Allen et al., 1998; Donchak et al., 2013). The granite at Mt. Carlton is a fine- to medium-grained monzogranite, containing equigranular quartz, alkali feldspar, plagioclase, biotite, and hornblende (unit 1; Figs. 4, 5, 6A, 7A). The granite basement unit is overlain by a volcanosedimentary sequence belonging to the Lizzie Creek Volcanic Group (units 2-8, Fig. 4; 288-275 Ma; I. Corral, unpub. data, 2018).

Near the Mt. Carlton mine, the basal unit of the Lizzie Creek sequence is a 300-m thick andesite unit (unit 2; Figs. $4,7)$. The rocks comprise fine-grained plagioclase-pyroxene \pm hornblende phyric andesite, and minor monomict autoclastic andesite breccia.

Overlying unit 2 is up to $200 \mathrm{~m}$ of massive and locally flow banded quartz-feldspar phyric rhyodacite, and minor monomict autoclastic quartz-feldspar phyric rhyodacite breccia (unit 3; Figs. 4, 5, 6B, C, 7). Unit 3 is affected by silicic and quartz-alunite alteration and hosts mineralization in the V2 pit.

An up to 100-m-thick unit of dacitic to rhyodacitic tuffs and sediments (unit 4; Figs. 4, 5, 7) overlies unit 3. Unit 4 has been subdivided into a lower unit (unit 4A) and an upper unit (unit 4B). Unit 4A comprises well-bedded, fragmental rhyodacite lapilli tuffs with interbedded carbonaceous lacustrine sediments, locally containing fossilized wood (Figs. 4, 5, 6D, 7). This unit occurs in both pits and hosts mineralization in the A39 pit. Unit 4B overlies unit 4A in the V2 pit and comprises massively bedded dacitic tuffs (Figs. 4, 5, 7).

Overlying unit 4 is a unit, up to $150 \mathrm{~m}$ thick, that contains dacitic and andesitic volcaniclastic rocks (unit 5; Figs. 4, 5, 7). These rocks show variable facies throughout the two pits and include dacitic ignimbrite (unit 5A), coarse volcanic conglomerate (unit 5B), and fragmental dacite breccia (unit 5C; Fig. 6E). 


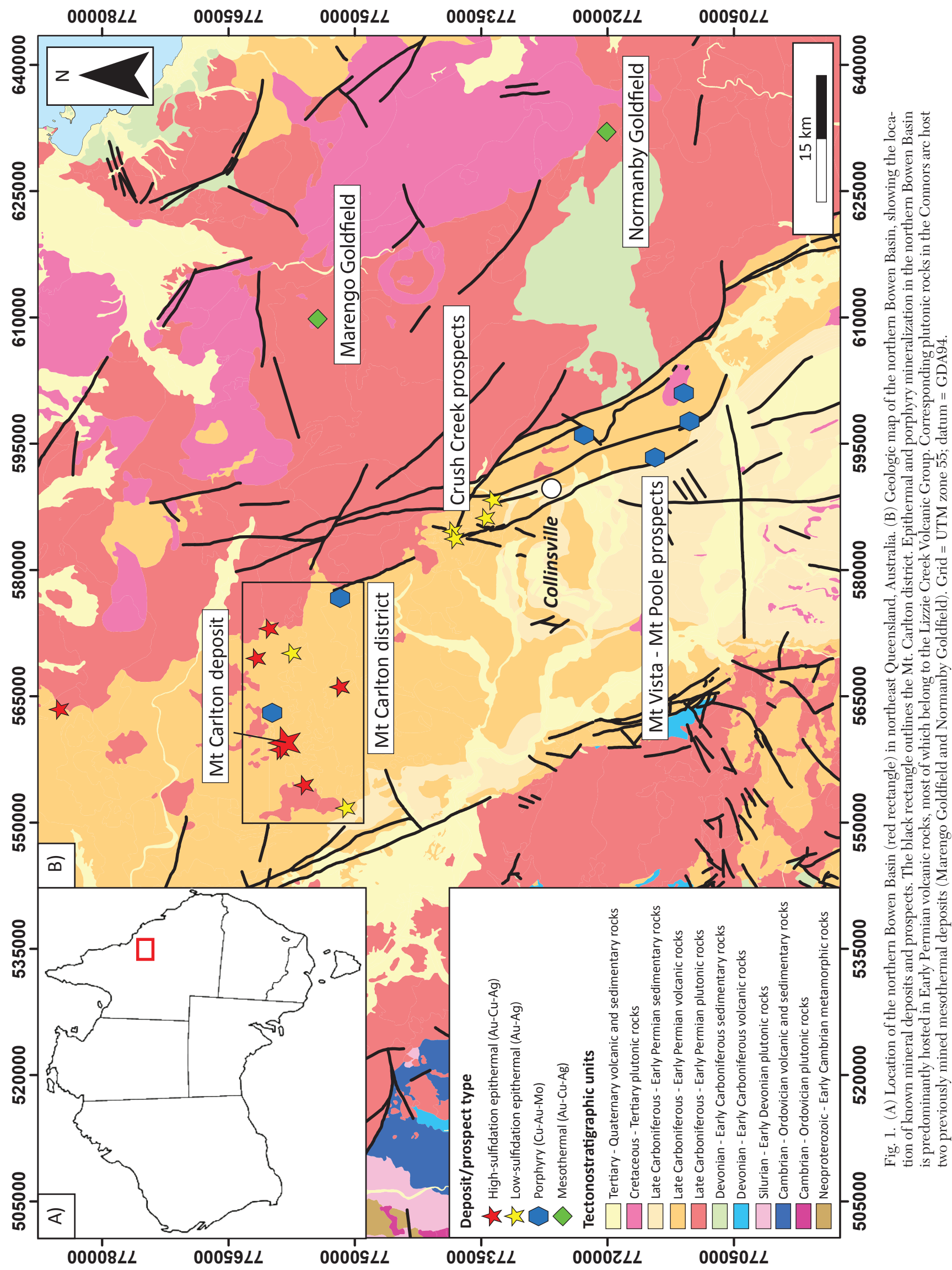



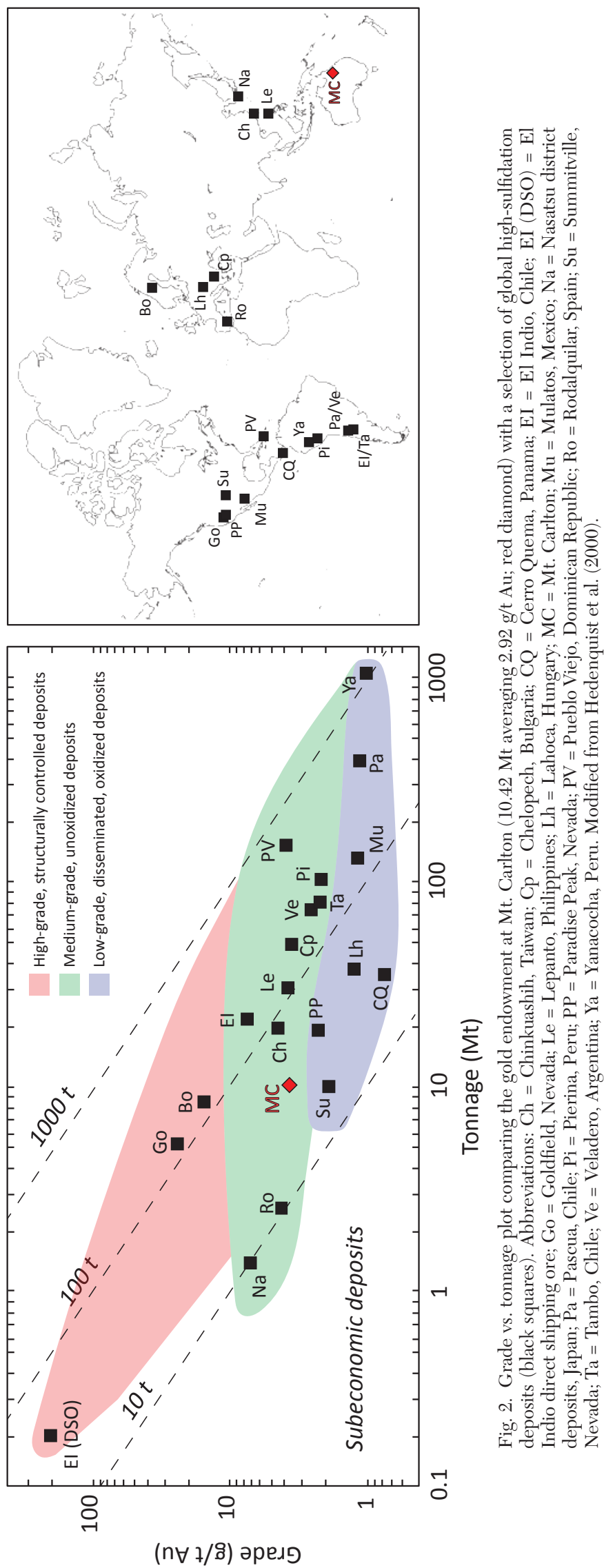

Unit 6 conformably overlies unit 5 in the area near the open pits. It is an up to 50-m-thick unit of fragmental andesite that locally contains rounded boulders (Figs. 4, 5, 6F, 7).

Unit 7 is an up to 150 -m-thick sequence of volcanosedimentary rocks that overlies unit 6 (Figs. 4, 5, 6F, 7). The rocks comprise andesitic to dacitic volcaniclastic breccias and volcanic sediments. The latter include water-laid, graded sandstone-siltstone beds, coal-bearing laminated mudstones with tuffaceous interbeds, and moderately to well-sorted, monomict to polymict fluvial conglomerates that locally contain clasts of hydrothermally altered granite and volcanic rocks (Fig. 6G). Porphyritic andesitic to dacitic lavas are locally present within unit 7 and occur in the northwest wall of the A39 pit (Figs. 4, 5, 7).

The youngest stratigraphic unit in the Mt. Carlton area, unit 8, comprises flow-banded rhyolites that conformably overlie units 1 to 7 throughout the district (Coughlin, 1995). The rocks contain aligned phenocrysts of lath-shaped plagioclase and alkali feldspar, and rare quartz, within an aphanitic, burgundy-red groundmass (Fig. 4). Unit 8 is exposed as a semihorizontal sheet along the hilltops to the south of the open pits.

In the north wall of the $\mathrm{V} 2$ pit, unit 3 is crosscut by a younger dacitic to rhyodacitic volcanic vent ( $25 \mathrm{~m}$ wide; Figs. 4, 5, 6C). This unit, here called unit 9, exhibits at least two distinct vent facies, including porphyritic, rhyodacitic lava with welldeveloped columnar jointing in the center and weakly layered, boulder-rich, tuffaceous, dacitic rocks along the margins.

\section{Deformation sequence}

A deformation sequence for the Mt. Carlton deposit has been established by structural mapping of the open pits and regional outcrops, coupled with analysis of drill core structural data. The Mt. Carlton deposit has undergone seven stages of extensional deformation and dike emplacement (herein called $\mathrm{D}_{1}-\mathrm{D}_{7}$ ), while no evidence for compressional deformation has been observed. The spatial distribution of stratigraphic units, hydrothermal alteration, and mineralization at Mt. Carlton is intimately linked to this deformation sequence, which can be summarized as follows:

$D_{1}$ : The $\mathrm{D}_{1}$ event constituted rifting and associated highangle normal faulting in response to both E-W and N-S extension. The $\mathrm{D}_{1}$ rifting event was initiated during the deposition of unit 2, was most intense during the deposition of units 3 and 4 , and was waning during the deposition of the younger stratigraphic units (units 5-8). The $\mathrm{D}_{1}$ normal faults exposed in the pits facilitated displacements on the order of tens of meters and include synsedimentary growth faults that were active during the deposition of volcanic sediments in localized half-graben and graben basins. Locally, such half-grabens infilled with Lizzie Creek volcanic rocks are bounded by $\mathrm{D}_{1}$ faults that also host mineralization (Fig. 8A, B). Hydrothermal enargite, pyrite, and dickite that grew along such faults define mineral lineations that record a normal component of shear (Fig. 8C, D). Hydrothermal alteration and epithermal mineralization, thus, occurred partly contemporaneously with rifting and deposition of volcanic sediments during the earlier stages of $\mathrm{D}_{1}$, with rifting and sedimentation outlasting mineralization.

$D_{2}$ : Continued E-W extension resulted in the development of 1- to 5-m-wide, low-angle (and locally layer-parallel) fault zones and associated, high-angle antithetic normal faults (Figs. 5, 6F, 7). Within the pit area, the $\mathrm{D}_{2}$ low-angle faults 


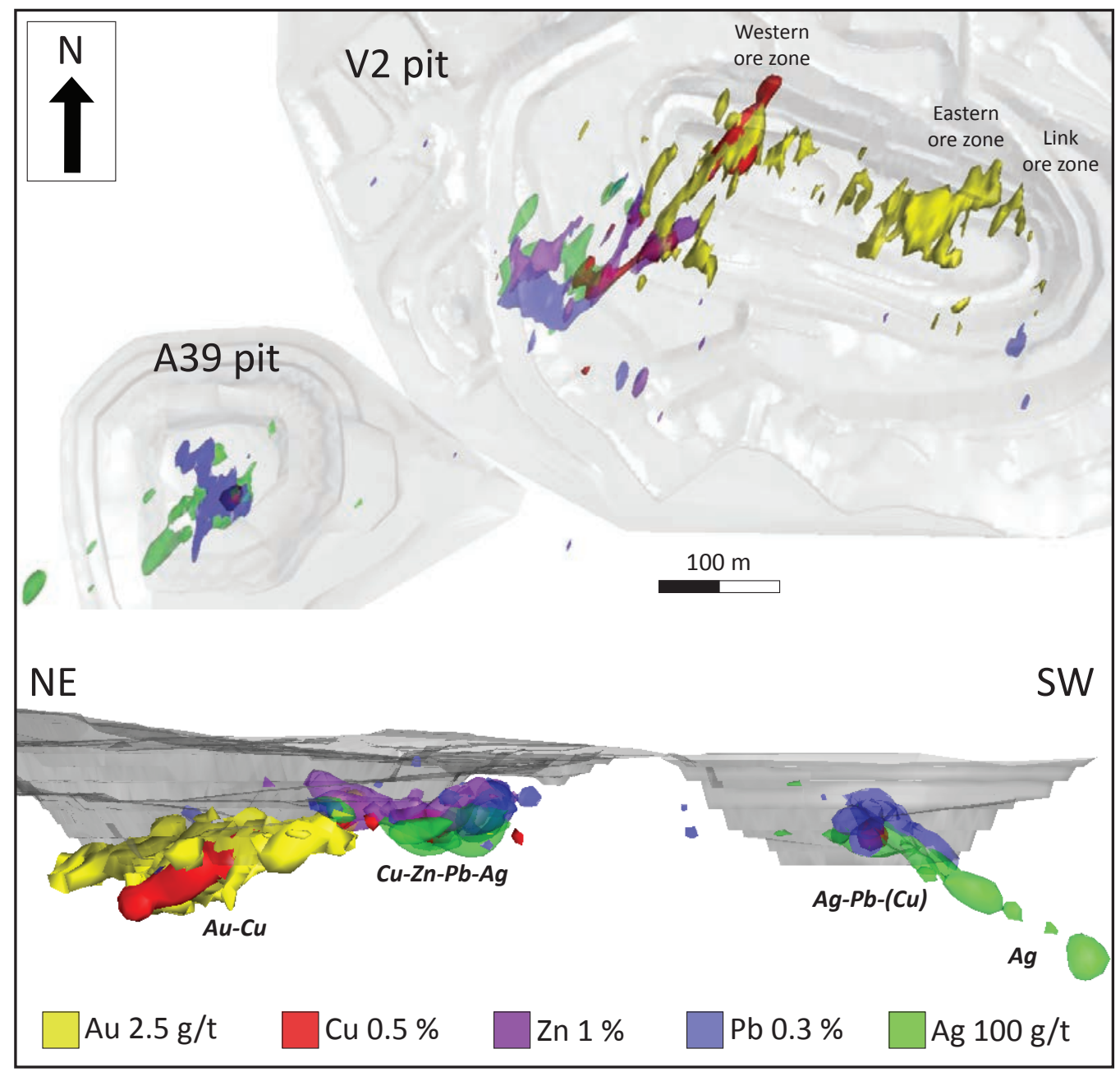

Fig. 3. 3-D model of the ore zones at Mt. Carlton, showing the metal zonation of $\mathrm{Au}, \mathrm{Ag}, \mathrm{Cu}, \mathrm{Zn}$, and $\mathrm{Pb}$ across the deposit. The grade shells were created in the Leapfrog Geo software using drill core assay data provided by Evolution Mining $(>3,500$ drill holes) and are fitted to a northeast-southwest structural trend.

accommodated a top-to-the-east displacement along a broadly $\mathrm{E}-\mathrm{W}$ axis, and they have truncated the stratigraphy, the hydrothermal alteration halo, and the ore zones (Figs. 5, 6F, 7). Major throughgoing $\mathrm{D}_{2}$ structures, with potential displacements of hundreds of meters, appear to be restricted to the younger stratigraphic units (i.e., unit 6 and above) that blanket the regional horst-and-graben topography created during $\mathrm{D}_{1}$. Where the $\mathrm{D}_{2}$ low-angle faults affect the lower parts of the stratigraphy, as can be seen in drill core, including the mineralized units 3 and $4 \mathrm{~A}$, the faults are relatively narrow $(<0.8 \mathrm{~m})$, and correlations between drill core indicate that displacements along these structures are smaller and more localized. The volcanic vent, unit 9 , crosscuts $\mathrm{D}_{2}$ faults in the $\mathrm{V} 2$ pit.

$D_{3}$ : The $\mathrm{D}_{3}$ event involved high-angle normal faulting in response to N-S extension, with partial reactivation of $\mathrm{D}_{1}$ and $\mathrm{D}_{2}$ faults. Based on the regional distribution of lithological units in the area (with basement granite to the north and a progressively thicker volcanosedimentary pile to the south), the overall sense of movement related to $\mathrm{D}_{3}$ faults around the V2 and A39 pits was probably south-down, resulting in a shallow, southerly tilt of the layering.
$D_{4}$ : The $\mathrm{D}_{4}$ event comprised block rotation of kilometerscale lithological domains across steep, NNW-trending normal faults and ENE-trending cross faults. An NNW-trending $\mathrm{D}_{4}$ normal fault cuts across the entire stratigraphic pile and passes between the V2 and A39 pits (Fig. 5). This has caused segmentation of the stratigraphy and the ore zones within the Mt. Carlton deposit, as well as a reorientation of primary layering and mineralization. Bedding planes in the northeast fault block, which includes the V2 pit, have remained nearhorizontal after the $\mathrm{D}_{4}$ event. In contrast, bedding planes in the southwest fault block, which includes the A39 pit, have been rotated in a west-southwest direction by $\sim 32^{\circ}$ (Fig. 5B).

$D_{5}$ : The $\mathrm{D}_{5}$ event constituted the emplacement of basaltic dikes along high-angle $\mathrm{D}_{1}, \mathrm{D}_{3}$, and $\mathrm{D}_{4}$ faults and, to a lesser degree, along low-angle $\mathrm{D}_{2}$ faults (Fig. $6 \mathrm{H}$ ). The dikes associated with the $\mathrm{D}_{5}$ event contain fine-grained plagioclase, pyroxene, and hornblende phenocrysts in a tan to dark green groundmass, showing a distinct "salt and pepper" texture.

$D_{6}$ : The $\mathrm{D}_{6}$ event involved strike-slip faulting along the margins of $\mathrm{D}_{5}$ dikes (Fig. $6 \mathrm{H}$ ). The movement was dominantly dextral, but sinistral movement has also been observed, 


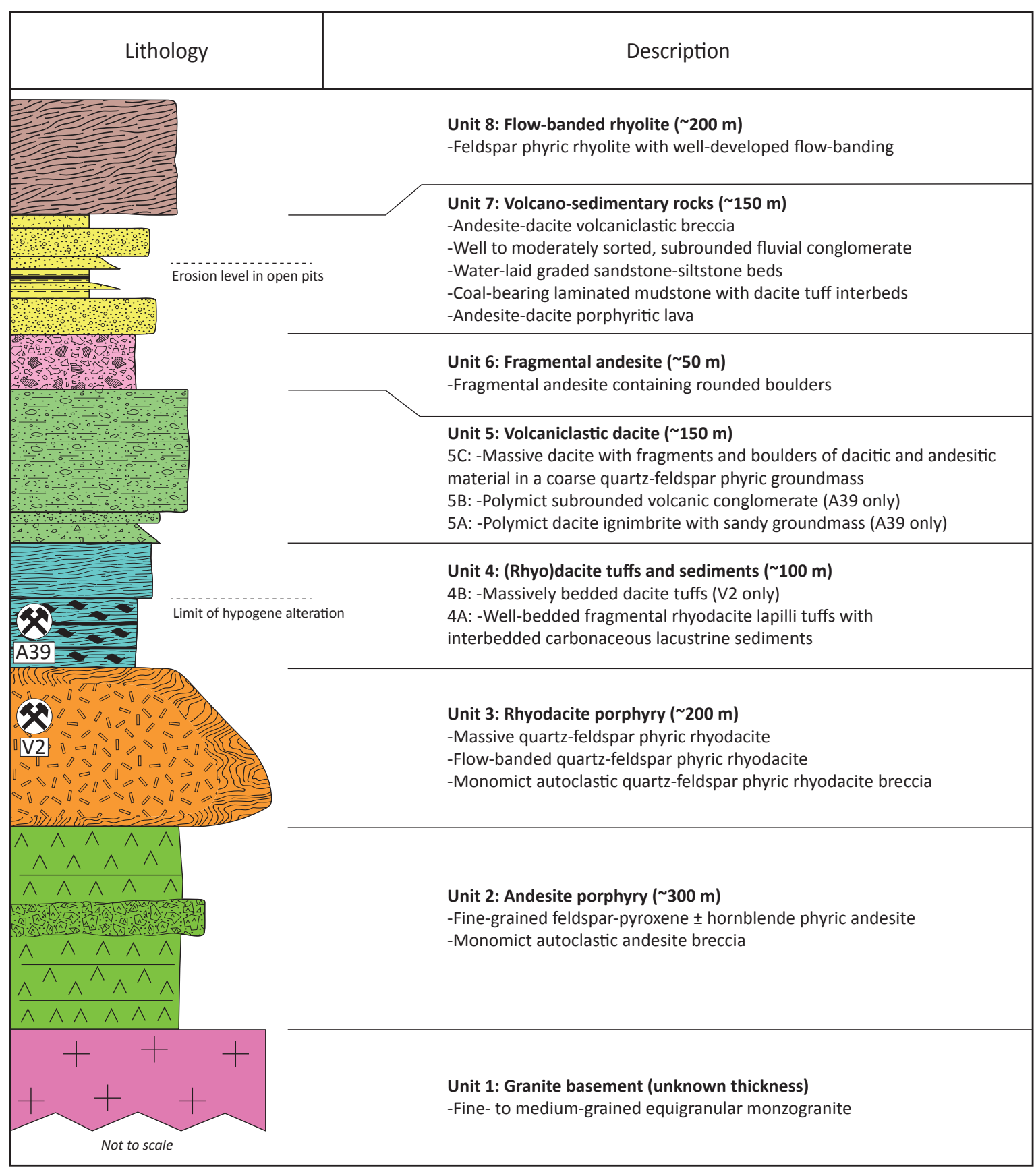

Fig. 4. Stratigraphic column for the Lizzie Creek Volcanic Group, as observed near the Mt. Carlton mine.

indicating a long and multistaged history of unknown age. The amount of displacement in the pit area during $\mathrm{D}_{6}$ events was minor (less than $20 \mathrm{~m}$ ).

$D_{7}$ : The $\mathrm{D}_{7}$ event comprised the emplacement of WNWtrending basaltic dikes. The $\mathrm{D}_{7}$ dikes exhibit a black aphanitic groundmass containing medium-grained plagioclase phenocrysts and quartz amygdales.

\section{Alteration Zones}

The mineralogy and zonation of alteration at Mt. Carlton was studied by drill core logging, open-pit mapping, transmitted polarized light microscopy, short-wave infrared (SWIR) spectroscopy, and powder X-ray diffraction (XRD). The SWIR analyses were made in situ on surface and drill core samples using a portable infrared mineral analyzer (PIMA) device, and data processing was done using the software "The Spectral Geologist" (TSG). The SWIR data collected in this study was complemented with an existing database of drill core SWIR data provided by Evolution Mining. This data was obtained using an ASD TerraSpec instrument and processed using TSG. The XRD analyses were performed using a PANalytical X'pert PRO automated diffractometer housed at the Swedish Museum of Natural History in Stockholm, and mineral identification was done using the Highscore Plus software. These 

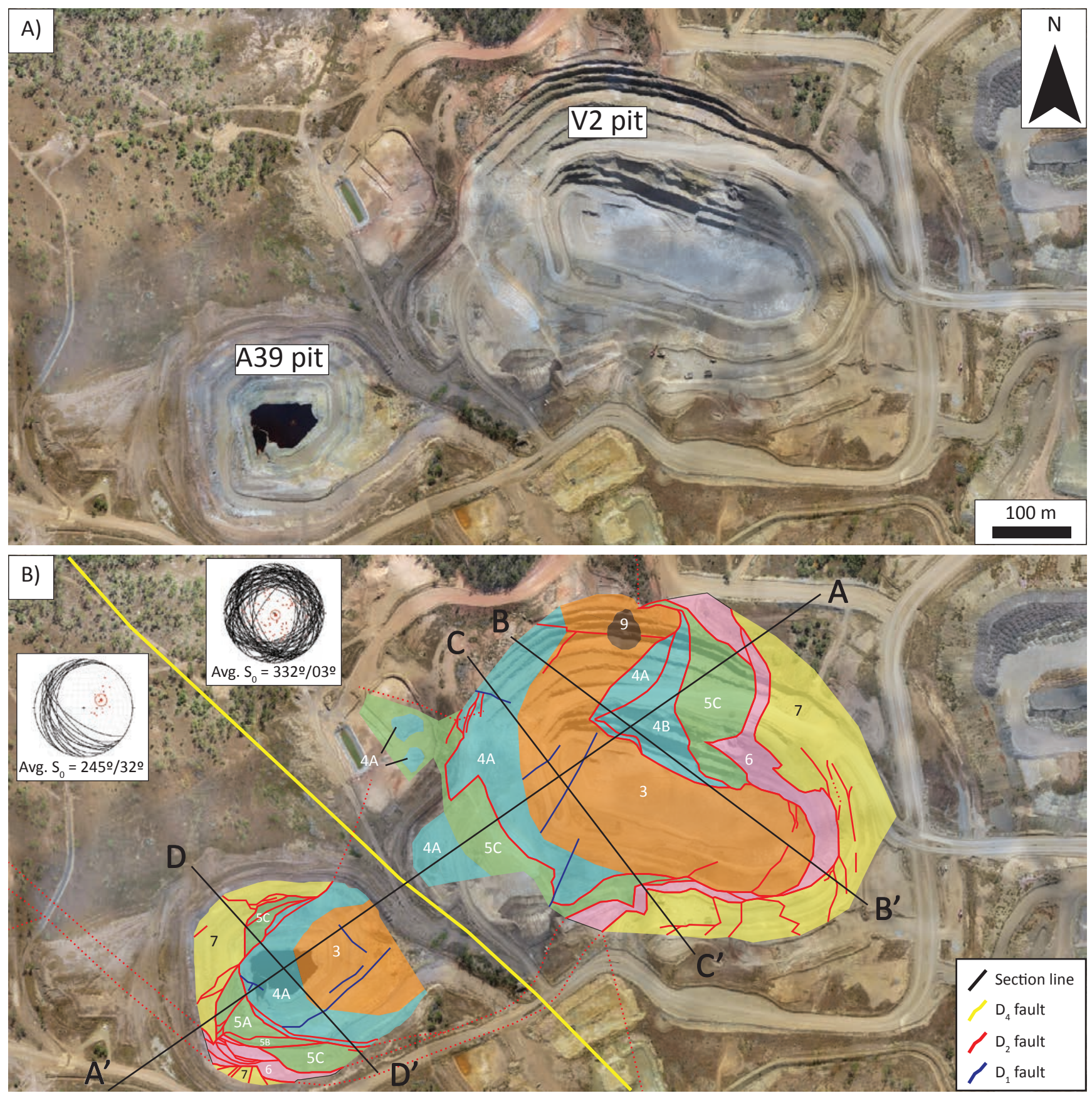

Fig. 5. (A) Aerial photograph of the V2 and A39 open pits at Mt. Carlton (as of September 2016). (B) Geologic map of the open pits. The lithological classification and legend are the same as in Figure 4. The solid colored lines delineate the major $\mathrm{D}_{1}, \mathrm{D}_{2}$, and $\mathrm{D}_{4}$ faults and the surface traces of the cross sections shown in Figure 7. The two inserted stereonets indicate the average orientation of primary bedding planes $\left(\mathrm{S}_{0}\right)$ within the two fault blocks separated by the NNW-trending $\mathrm{D}_{4}$ normal fault. The red dotted lines represent inferred faults outside of the mapped open pits.

studies have resulted in the identification of five distinct alteration zones.

\section{Silicic alteration zone}

Silicic alteration occurs as multiple cores $(\sim 10-100 \mathrm{~m}$ wide) that formed in and around $\mathrm{D}_{1}$ high-angle structures in units 3 and $4 \mathrm{~A}$ (Fig. 7). The silicic alteration zones are characterized by almost complete replacement of the original rock by microcrystalline quartz, which has produced a very hard residual rock. Silicic alteration has largely destroyed primary volcanic and sedimentary textures, such that, in general, only quartz phenocrysts are preserved. The texture of silicic alteration is predominantly massive, but vuggy textures and silicic hydrothermal breccias are developed locally. The silicic alteration zones contain small amounts of alunite, pyrite, dickite, kaolinite, aluminum-phosphate-sulfate (APS) 

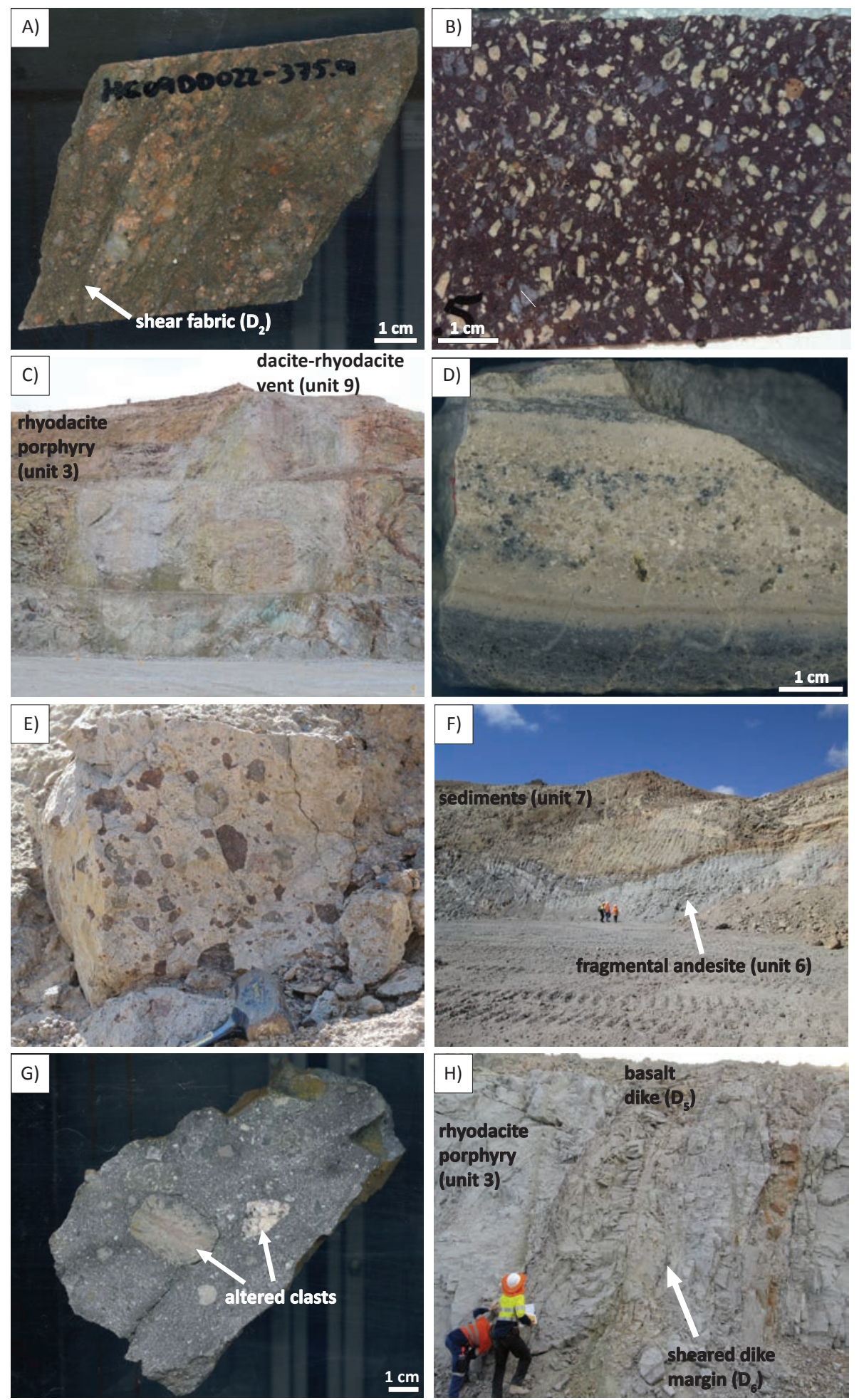

Fig. 6. Photographs of selected stratigraphic units and structures at Mt. Carlton. (A) Monzogranite basement (unit 1) showing a strong shear fabric related to $\mathrm{D}_{2}$ deformation. (B) Fresh quartz-feldspar phyric rhyodacite (unit 3), the host of mineralization in the V2 pit. (C) A dacite-rhyodacite vent (unit 9) crosscuts the mineralized rhyodacite porphyry (unit 3) as well as $\mathrm{D}_{2}$ faults in the north wall of the V2 pit. The vent locally has kaolinite-pyrite alteration in its core and illite-montmorillonite alteration along its margins. (D) Laminated volcanolacustrine sediments (unit 4A), the host of mineralization in the A39 pit. (E) Fragmental dacite breccia (unit 5C) from the A39 pit. (F) Contact between a highly sheared fragmental andesite (unit 6) and water-laid sediments (unit 7) in the east wall of the $\mathrm{V} 2$ pit. Unit 6 constitutes a major layer-parallel $\mathrm{D}_{2}$ normal fault. Note the large-scale rotational block faulting of the overlying sedimentary layers. (G) Polymict conglomerate from the volcanosedimentary unit (unit 7) in the V2 pit, containing clasts of hydrothermally altered rocks. (H) E-trending $\mathrm{D}_{5}$ basaltic dikes crosscutting massive rhyodacite porphyry (unit 3) in the east wall of the V2 pit. The dikes have minor displacements along their margins related to $\mathrm{D}_{6}$ deformation. 
A

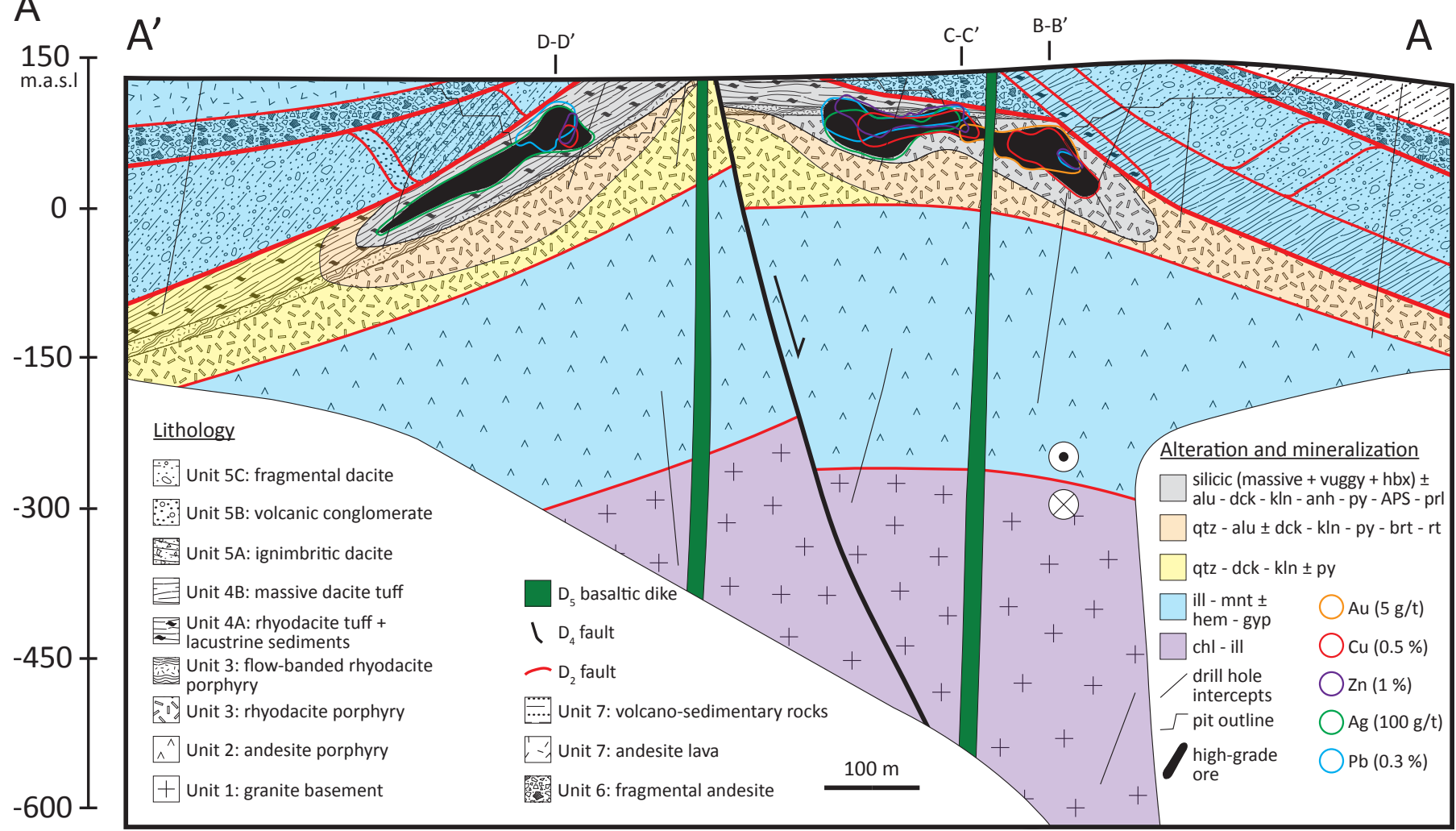

B

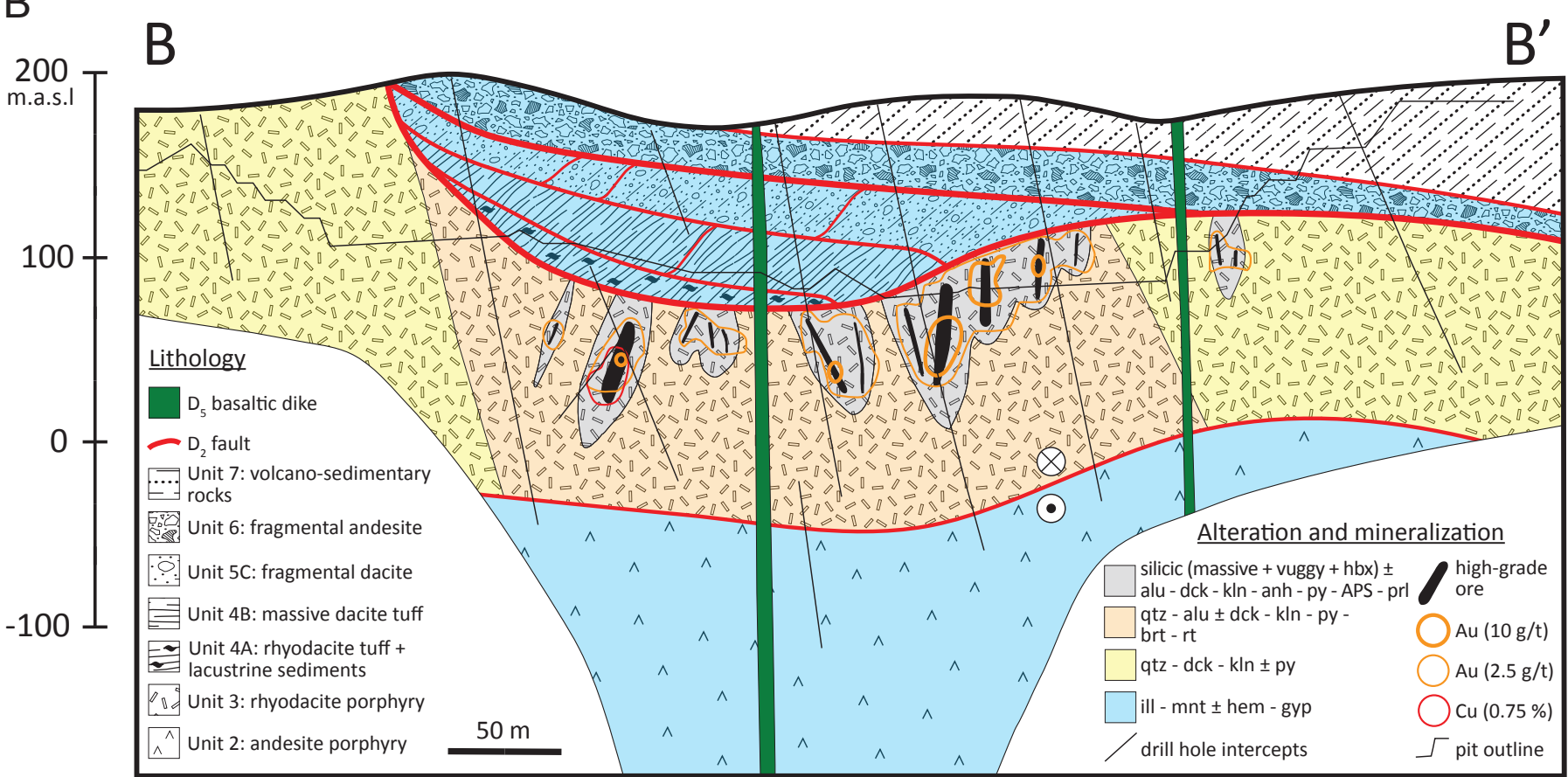

Fig. 7. Interpreted cross sections through the Mt. Carlton deposit, showing the distribution of stratigraphic units, major structures, alteration assemblages, and mineralization. The sections were drawn based on drill core logging, open-pit mapping, SWIR measurements, and Leapfrog modeling. (A) Long section from northeast to southwest along the Western ore zone, corresponding to line A-A' in Figure 5. (B) Cross section from northwest to southeast through the central V2 pit, corresponding to line B-B' in Figure 5. (C) Cross section from northwest to southeast through the southwest V2 pit, corresponding to line C-C' in Figure 5. (D) Cross section from northwest to southeast through the central A39 pit, corresponding to line D-D' in Figure 5. Abbreviations: alu = alunite, anh = anhydrite, APS = aluminum phosphate-sulfate, brt $=$ barite,, $\mathrm{chl}=$ chlorite, dck = dickite, gyp = gypsum, $\mathrm{hbx}=$ hydrothermal breccia, hem $=$ hematite, ill $=$ illite, $\mathrm{kln}=$ kaolinite, mnt $=$ montmorillonite, $\mathrm{prl}=$ pyrophyllite, py $=$ pyrite, $\mathrm{qtz}=$ quartz, $\mathrm{rt}=$ rutile . 


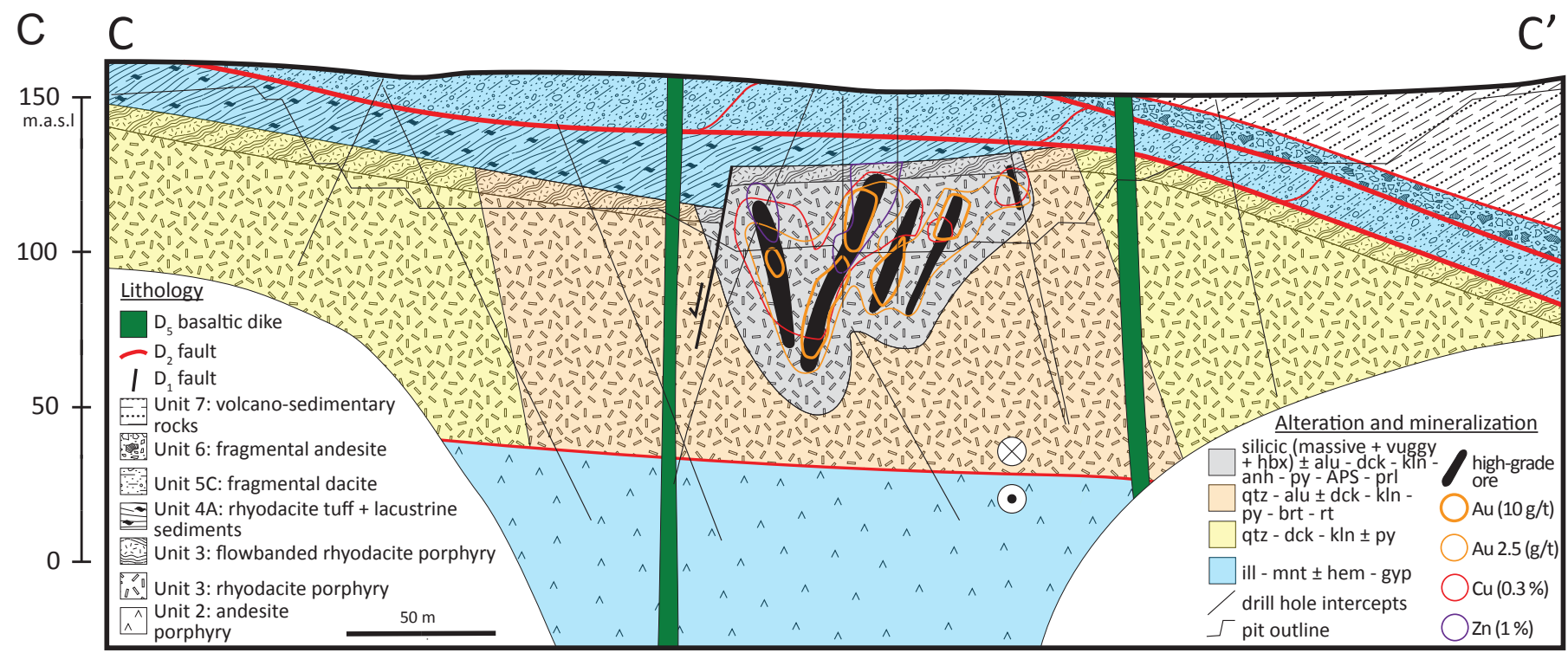

D

D

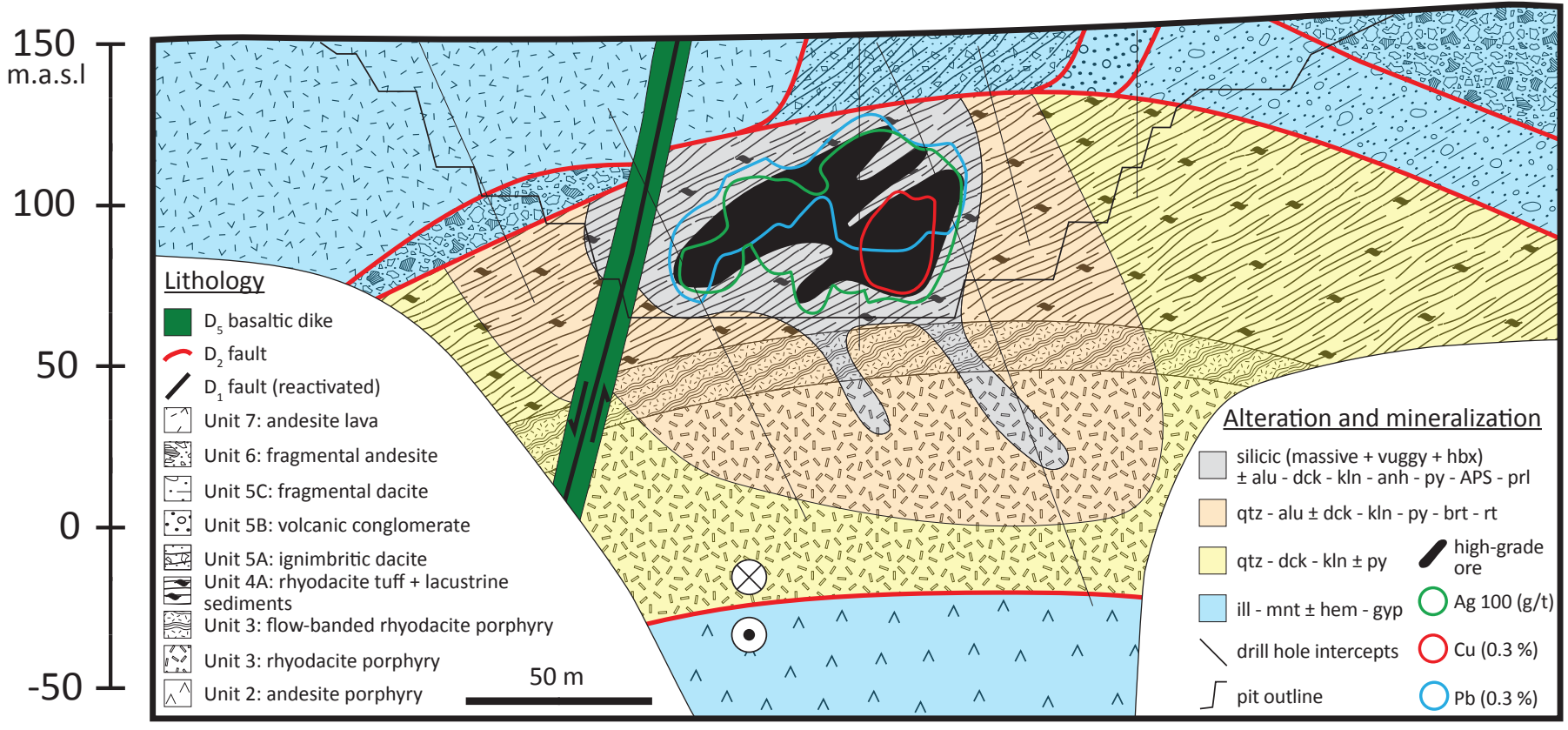

Fig. 7. (Cont.)

minerals, and pyrophyllite (Fig. 9). Pyrite occurs as disseminations in the quartz groundmass, while the sulfate and clay minerals are mainly developed in vugs or as infill in hydrothermal breccia (Fig. 10A). The presence of pyrophyllite was only identifiable using SWIR and XRD techniques. The silicic alteration zones locally contain aggregates of tabular anhydrite, which are developed within small fractures (Fig. 10B). Most of the anhydrite has been dissolved, which has left behind a prominent cast texture in the rock (Fig. 10C). The silicic alteration zones also locally contain alunite veins (Fig. 9). These veins are up to $\sim 20 \mathrm{~cm}$ wide and made up of banded, plumose alunite without sulfides (Fig. 10D). Based on textural observations in thin section, some alunite veins are synchronous with silicic alteration, whereas others postdate it. The presence of alunite veins is largely concentrated to the V2 pit; however, they have been observed locally in the A39 pit too. Many alunite veins were reopened by later mineralized veins (Fig. 10D).

\section{Quartz-alunite alteration zone}

A quartz-alunite alteration zone defines a 100- to 300-m-wide envelope to the silicic alteration zones in units 3 and $4 \mathrm{~A}$, with a gradational transition between the two zones (Fig. 7). Quartzalunite alteration is not as pervasively developed as the silicic alteration, such that primary rock textures are generally preserved. A groundmass of microcrystalline quartz contains disseminated alunite and locally pyrite, dickite, and kaolinite, and, more rarely, barite and rutile (Figs. 9, 10E). Alunite and 

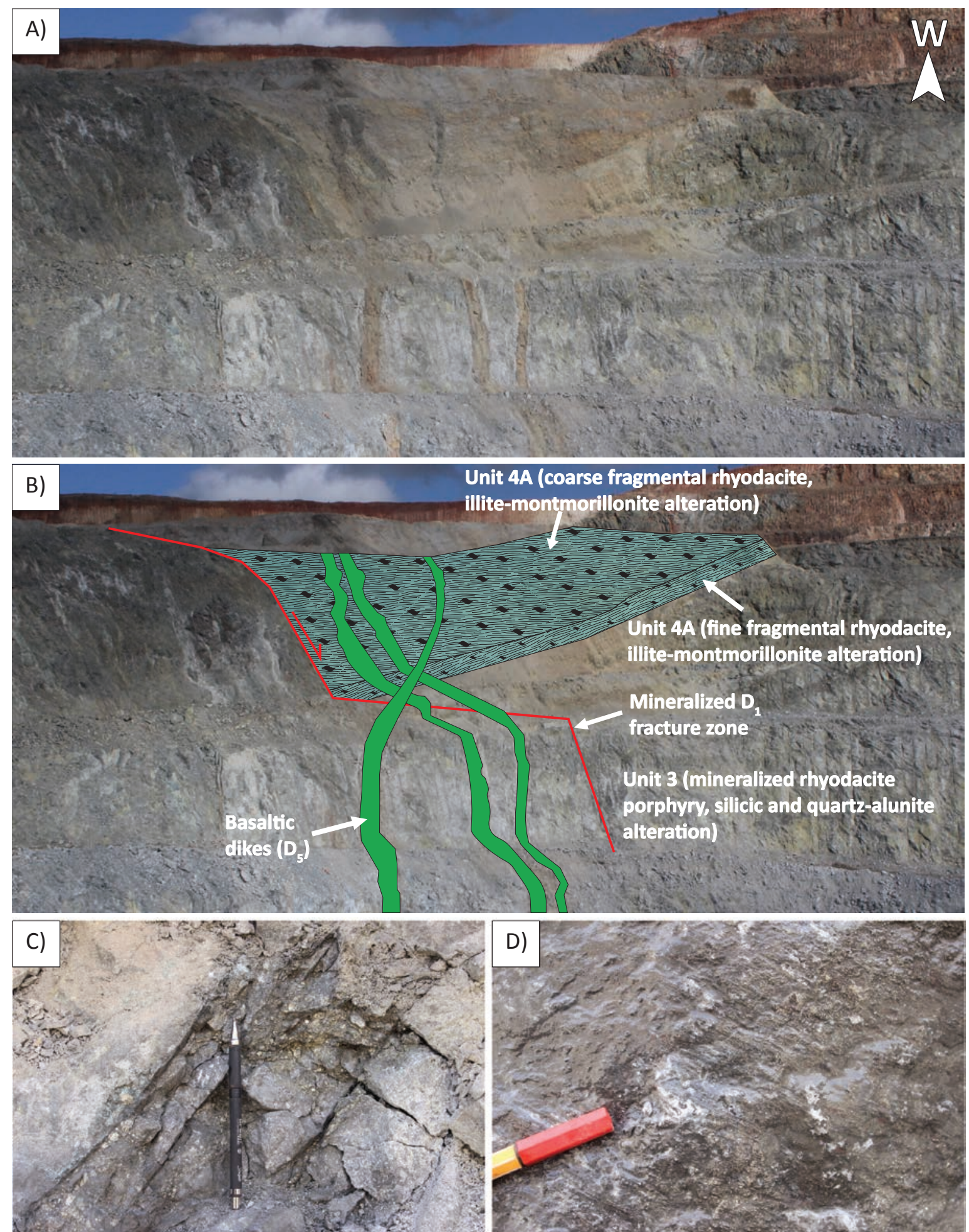

Fig. 8. Photographs showing key field relationships associated with the $\mathrm{D}_{1}$ deformation event. (A, B) Outcrop from the southwest wall of the V2 pit, illustrating the partial overlap between rifting, sedimentation, mineralization, and alteration during $\mathrm{D}_{1}$. An NNE-trending, steeply $W$ dipping $\mathrm{D}_{1}$ fracture zone (drawn in red) is mineralized and merges with the mineralized fracture system within the silicic and quartz-alunite altered unit 3 in the lower bench. A half-graben structure is bounded to the southeast by this fracture zone, and the half-graben is infilled with younger, postmineralization rhyodacitic volcanic sediments (unit 4A). These rocks exhibit illite-montmorillonite alteration, indicating that this alteration (unlike the silicic and quartz-alunite alteration in unit 3) formed after mineralization. The outcrop is crosscut by E-trending basaltic dikes emplaced during $D_{5}$. (C) Photograph of hydrothermal enargite and pyrite that grew along a $D_{1}$ fracture in the Eastern ore zone in the V2 pit. (D) A mineral lineation is defined by enargite, pyrite, and dickite that grew along a $\mathrm{D}_{1}$ fracture in the Eastern ore zone in the $\mathrm{V} 2$ pit. The lineation trends east, and movement on the fault was sinistral normal. 


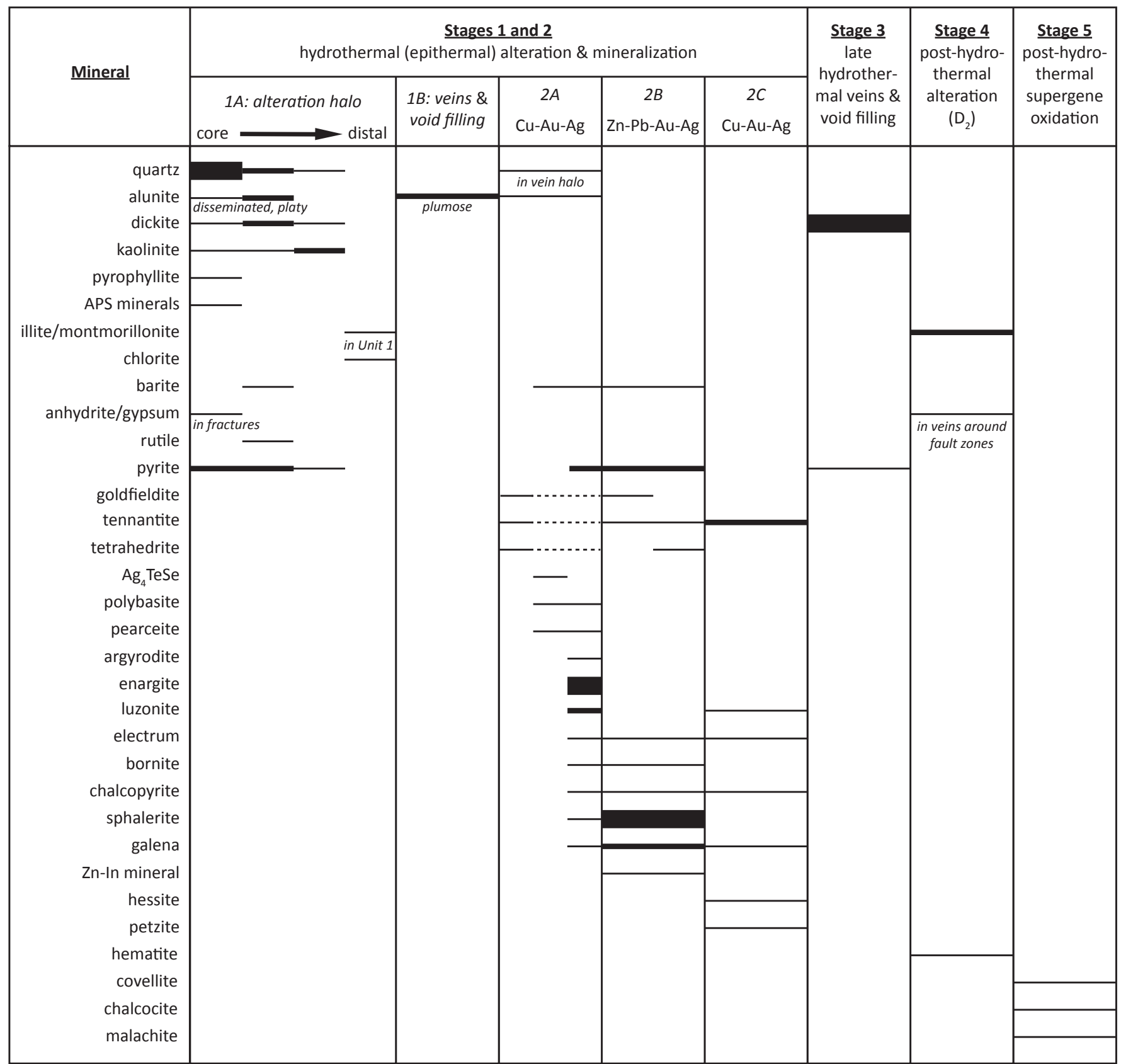

dominant mineral

common mineral

minor mineral

Fig. 9. Paragenetic sequence of alteration and ore minerals at Mt. Carlton. See text for discussion of stage 1 alteration within units 3 and 4A, which host the Mt. Carlton hydrothermal mineralization and void fill (stages 2 and 3 above), versus stage 4 alteration within units $2,4,5$, and 6 , which occur above or below mineralization.

clay minerals have also replaced preexisting feldspar crystals (Fig. 10E).

\section{Quartz-dickite-kaolinite alteration zone}

A quartz-dickite-kaolinite alteration zone occurs as a laterally extensive (>1-km-wide) halo to the silicic and quartz-alunite alteration zones in units 3 and 4A (Fig. 7). Quartz-dickitekaolinite alteration produced a whitish- to gray-colored rock that typically preserves primary volcanic and sedimentary textures. A groundmass of microcrystalline quartz contains disseminated dickite, kaolinite and, locally, pyrite (Fig. 9). Dickite and kaolinite have also replaced preexisting feldspar crystals (Fig. 10F). The amount of quartz decreases away from the controlling structures, such that dickite-kaolinite altered rocks are relatively soft and friable in distal locations. Kaolinite-pyrite alteration is also locally present within unit 9 (Fig. 6C). 

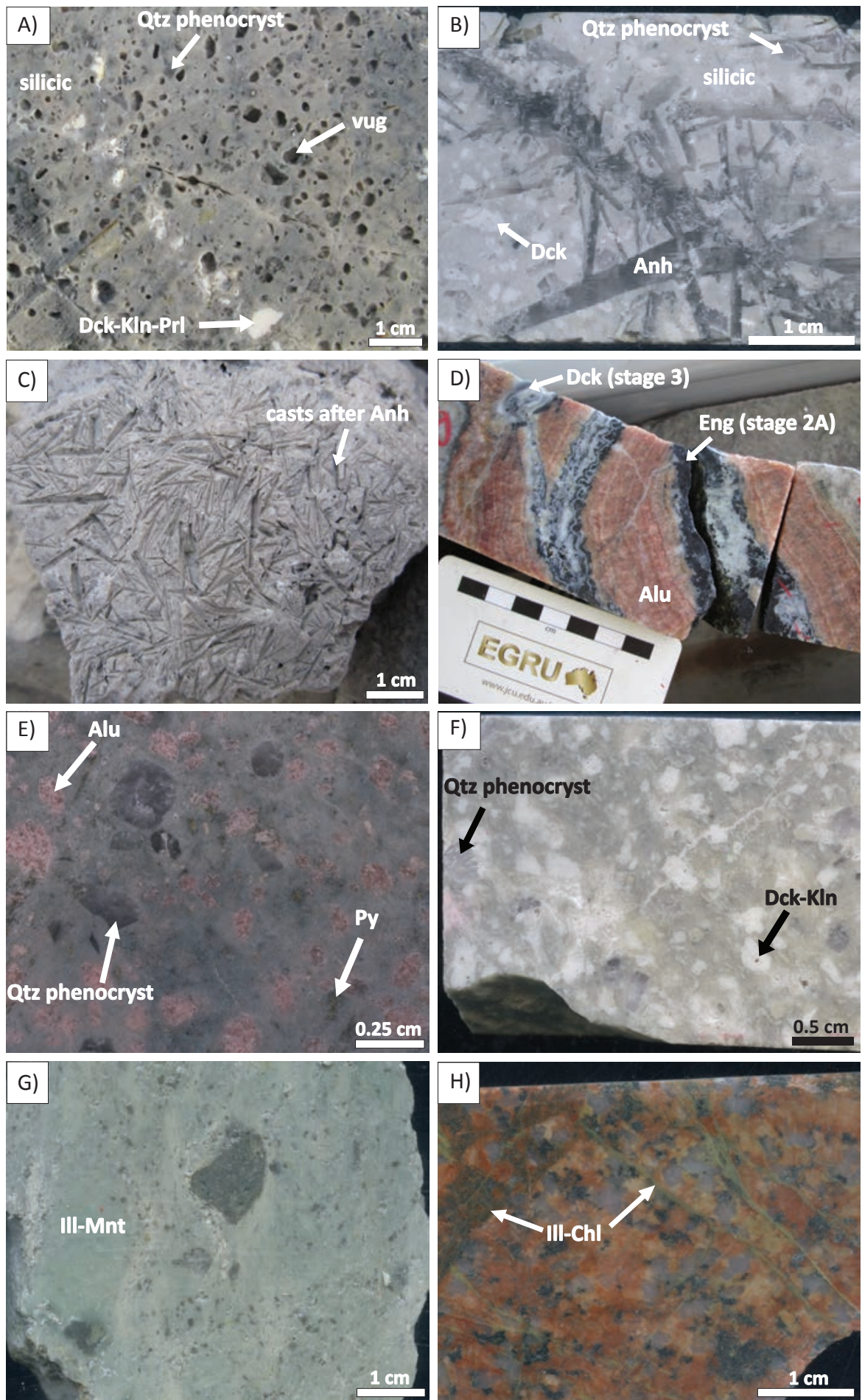

Fig. 10. Photographs of selected hydrothermal alteration assemblages at Mt. Carlton. (A) Silicic alteration with a vuggy texture, reflecting the leaching effects of highly acidic fluids. The vugs are partly infilled with dickite, kaolinite, and pyrophyllite. (B) Silicic alteration containing aggregates of tabular anhydrite formed within small fractures. Preexisting feldspar crystals have been replaced by dickite. (C) Similar alteration as in (B) but with the anhydrite having been completely dissolved, leaving behind a prominent cast texture in the rock. (D) Banded alunite vein developed within a silicic alteration zone. After deposition of alunite, the vein was reopened to form two stage $2 \mathrm{~A}$ enargite veins. The composite vein was then overprinted by stage 3 dickite. (E) Quartz-alunite-pyrite alteration developed in a quartz-feldspar phyric rhyodacite (unit 3). Alunite has mainly replaced preexisting feldspar crystals, while the pyrite occurs as disseminations. (F) Quartz-dickite-kaolinite alteration developed in a quartz-feldspar phyric rhyodacite (unit 3). The clay minerals have replaced preexisting feldspars. (G) Illitemontmorillonite alteration developed in a volcaniclastic dacite (unit 4B). (H) Veinlets of chlorite and illite crosscutting the granite basement rocks (unit 1). Mineral abbreviations (Kretz, 1983): Alu = alunite, Anh $=$ anhydrite, $\mathrm{Chl}=$ chlorite, Dck = dickite, $\mathrm{Eng}=$ enargite, $\mathrm{Ill}=$ illite, $\mathrm{Kln}=$ kaolinite, $\mathrm{Mnt}=$ Montmorillonite, $\mathrm{Prl}=$ pyrophyllite, $\mathrm{Py}=$ pyrite, $\mathrm{Qtz}=$ quartz. 


\section{Illite-montmorillonite alteration zone}

The zoned alteration halo developed in unit 3 and unit 4A (silicic $\rightarrow$ quartz-alunite $\rightarrow$ quartz-dickite-kaolinite) shows sharp transitions with respect to mineralogy across sheared $\left(D_{2}\right)$ contacts to the units overlying and underlying it, which include units 2, 5, and 6 and parts of unit 4 (Fig. 7). Illitemontmorillonite alteration is pervasive in rocks above and below the fault-bounded ore zones (Figs. 7, 9, 10G). These peripheral rocks are very friable and poorly preserved, due to the swelling properties of the clay minerals. In addition to illite and montmorillonite, these distal rocks locally exhibit red hematite dusting. Syntectonic gypsum veins with welldeveloped shear fabrics occur near the major $\mathrm{D}_{2}$ faults within the illite-montmorillonite alteration zones.

\section{Chlorite-illite alteration zone}

The illite-montmorillonite alteration zone transitions downward to a chlorite-illite alteration zone (Figs. 7A, 9). This transition is sharp and is again controlled by a $\mathrm{D}_{2}$ fault along the contact between unit 2 and the granite basement. Chloriteillite alteration occurs as green veinlets that crosscut the primary granitic texture (Fig. 10H). Chlorite and illite have also replaced preexisting feldspar, hornblende, and biotite crystals.

\section{Timing of the alteration assemblages}

The zoned alteration halo present within unit 3 and unit 4A (silicic $\rightarrow$ quartz-alunite $\rightarrow$ quartz-dickite-kaolinite) is interpreted to be directly linked to the mineralizing hydrothermal event at Mt. Carlton, based on its close spatial relationship with mineralization, and also based on comparisons to other highsulfidation deposits (e.g., Steven and Ratté, 1960; Stoffregen, 1987; Arribas, 1995a; Hedenquist et al., 2000). In contrast, the illite-montmorillonite alteration is partly developed in units that were deposited after mineralization (Figs. 7, 8) and shows no obvious zonation. Therefore, we interpret this alteration assemblage to have developed regionally during $\mathrm{D}_{2}$ deformation. Chlorite-illite alteration of the granite basement was most likely related to the mineralizing hydrothermal event. This is based on the presence of chlorite-illite altered granite clasts in conglomerates within unit 7 , which predates $\mathrm{D}_{2}$ deformation.

The presence of pyrite together with kaolinite in unit 9 implies a hypogene origin for kaolinite alteration. Because unit 9 crosscuts both the primary hydrothermal alteration halo and $\mathrm{D}_{2}$ faults in unit 3, a later hydrothermal alteration event (likely occurring concomitantly with the emplacement of the volcanic vent itself) is inferred to have overprinted the earlier alteration halo in unit 3. This late-stage alteration appears to be confined to within and proximal to unit 9 (Fig. 6C).

\section{Mineralization}

The ore geometry, metal zonation, and mineral paragenesis at Mt. Carlton was studied by open-pit mapping, drill core logging, modeling of drill core assay data using Leapfrog, whole-rock geochemical analyses, reflected polarized light microscopy, and reconnaissance scanning electron microscopy with an energy dispersive scanning system (SEM-EDS).

\section{Ore geometry and metal zonation}

On a local scale $(1-10 \mathrm{~m})$, proximal $\mathrm{Au}-\mathrm{Cu}$ mineralization in the V2 pit occurs in moderately to steeply $\left(\sim 60^{\circ}-90^{\circ}\right)$ dipping
$D_{1}$ fracture networks within the rhyodacite porphyry (unit 3). The mineralized fractures have a predominantly northeast to north-northeast trend, with NW- to E-trending fractures being secondary. Hydrothermal breccias infilled with ore minerals are locally developed along intersection lines between mineralized fractures (Fig. 11A). At a scale of hundreds of meters, three distinct ore zones can be identified in the V2 pit (Western, Eastern, and Link ore zones; Fig. 3). These ore zones line up in an en echelon fashion along a broadly E trending corridor, and all have grade envelopes that trend southwest. The Eastern and Link ore zones terminate in the V2 pit, while the Western ore zone extends to the southwest and can be traced into the A39 pit across a $\mathrm{D}_{4}$ fault. Along strike of the $\sim 600 \mathrm{~m}$ of known mineralization, the Western ore zone shows a distinct metal zonation, from proximal to distal, of $\mathrm{Au}-\mathrm{Cu} \rightarrow \mathrm{Cu}-\mathrm{Zn}-\mathrm{Pb}-\mathrm{Ag} \rightarrow$ Ag-Pb-(Cu) $\rightarrow$ Ag (Figs. 3, 7). Distal Ag mineralization is concentrated in the A39 pit, where it occurs in the volcanolacustrine sediments (unit 4A) that overlie the rhyodacite porphyry. Pit mapping in combination with the analysis of structural and stratigraphic data in drill core reveal that mineralization in A39 occurs in a stratabound position oriented parallel to primary sedimentary layering. Furthermore, mineralization in A39 is distributed parallel to the lineation defined by the intersection between the sedimentary bedding planes in unit $4 \mathrm{~A}$ and the mineralized feeder structures in the underlying unit 3.

The high-grade ore and associated hydrothermal alteration halo within the Western ore zone has been dismembered by an NNW-trending $\mathrm{D}_{4}$ normal fault that is positioned between the two open pits (Figs. 3, 5B, 7A). Due to the rotation of the southwest fault block that contains A39, the originally subhorizontal Ag ore in A39 now plunges to the southwest (Figs. $3,5 \mathrm{~B}, 7 \mathrm{~A}$ ). The feeder system in V2 occurs essentially in its original, steep orientation, since the rotation of the northeast fault block was negligible (Fig. 5B).

\section{Paragenetic sequence}

The zoned hydrothermal alteration assemblages in units 3 and 4A (stage 1; Fig. 9) are crosscut by three stages of epithermal mineralization (stages 2A-C). The ores were, in turn, overprinted by a late stage of dickite and pyrite void fill (stage 3 ). Following $\mathrm{D}_{2}$ deformation and associated alteration (stage 4), a final stage of supergene oxidation (stage 5) locally overprinted the mineralized rocks. Because the paragenetic sequence is identical in V2 and A39, we infer that the now segmented Western ore zone originally formed as a single hydrothermal system. Both stage $2 \mathrm{~A}$ and stage $2 \mathrm{~B}$ mineralization contain high-grade Au (locally $>600 \mathrm{ppm}$; Table 1) and $\mathrm{Ag}$, as well as variable amounts of base metals (e.g., $\mathrm{Cu}, \mathrm{Zn}$, and $\mathrm{Pb}$ ) and rare metals (e.g., Ge, Ga, In, Te, Se, Sn). The deposit-scale metal zonation shown in Figure 3 is caused in part by the temporal zonation of metals through stages $2 \mathrm{~A}$ to C (Fig. 9), and in part by the spatial zonation of metals within each individual stage (Table 1).

\section{$\mathrm{Cu}$-Au-Ag mineralization (stage $2 \mathrm{~A}$ )}

Stage $2 \mathrm{~A}$ was the initial and most voluminous mineralization event at Mt. Carlton and developed in all three ore zones. It produced a high-sulfidation-state ore mineral assemblage dominated by massive enargite, and mineralization was associated 

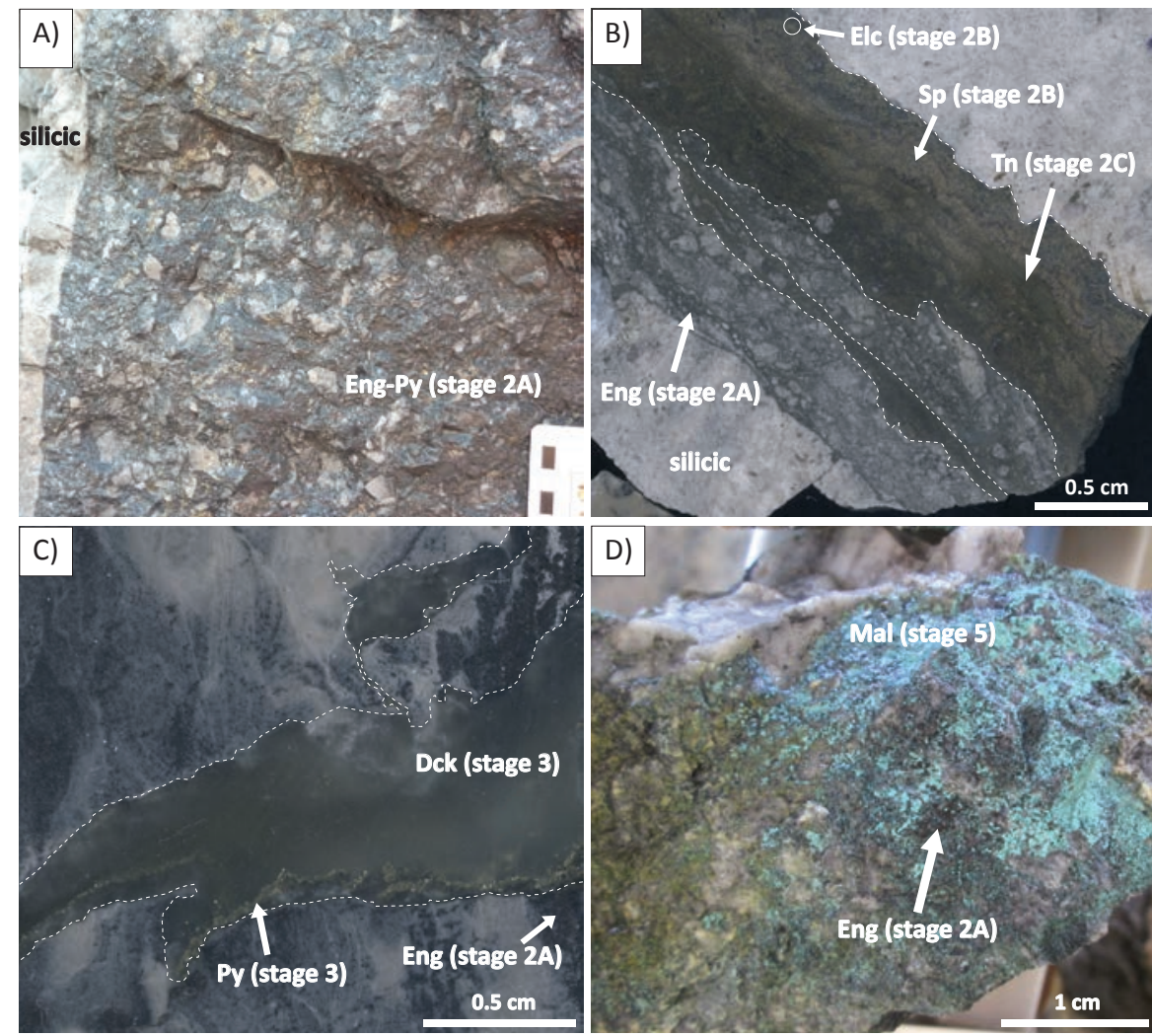

Fig. 11. Photographs of mineralization stages at Mt. Carlton. (A) Silicic hydrothermal breccia cemented with stage $2 \mathrm{~A}$ enargite-pyrite ore (from the V2 pit). (B) Silicic altered rhyodacite porphyry crosscut by a fine hydrothermal breccia infilled with stage $2 \mathrm{~A}$ enargite ore. The enargite breccia is crosscut by a stage $2 \mathrm{~B}$ sphalerite vein containing visible grains of electrum. The sphalerite vein is, in turn, locally overprinted by stage $2 \mathrm{C}$ tennantite (from the V2 pit). (C) Disseminated stage $2 \mathrm{~A}$ enargite mineralization crosscut by a stage 3 dickite-pyrite vein (from the A39 pit). (D) Supergene malachite (stage 5) developed on stage 2A enargite ore (from the V2 pit). Mineral abbreviations (Kretz, 1983): Dck = dickite, Elc = electrum, Eng = enargite, $\mathrm{Mal}=$ malachite, $\mathrm{Py}=$ pyrite, $\mathrm{Sp}=$ sphalerite, $\mathrm{Tn}=$ tennantite .

with silicic alteration of the wall rocks (Figs. 9, 11A). The first minerals to crystallize in the stage $2 \mathrm{~A}$ assemblage were tetrahedrite-group minerals. These occur as up to $\sim 100-\mu \mathrm{m}$-diameter, subhedral crystals that are zoned in backscattered electron (BSE) images (Fig. 12A). The tetrahedrite-group minerals are overprinted by silver minerals (Fig. 12A), which include minerals of the pearceite-polybasite group $\left(\left[\mathrm{Ag}_{9} \mathrm{CuS}_{4}\right]\right.$ $\left.\left[(\mathrm{Ag}, \mathrm{Cu})_{6}(\mathrm{As}, \mathrm{Sb})_{2} \mathrm{~S}_{7}\right]-\left[\mathrm{Ag}_{9} \mathrm{CuS}_{4}\right]\left[(\mathrm{Ag}, \mathrm{Cu})_{6}(\mathrm{Sb}, \mathrm{As})_{2} \mathrm{~S}_{7}\right]\right)$ and $\mathrm{Ag}_{4} \mathrm{TeSe}-\mathrm{a}$ not fully characterized analogue to aguilarite $\left(\mathrm{Ag}_{4} \mathrm{SeS}\right)$ and cervelleite $\left(\mathrm{Ag}_{4} \mathrm{TeS}\right)$. The tetrahedrite-group minerals and silver minerals were, in turn, overprinted by the main enargite assemblage, which includes pyrite and luzonite and, to a lesser degree, electrum, sphalerite, galena, chalcopyrite, bornite, and argyrodite $\left(\mathrm{Ag}_{8} \mathrm{GeS}_{6}\right.$; Figs. 9, 12A-C). The electrum occurs as up to $\sim 100-\mu \mathrm{m}$-diameter, anhedral to subhedral grains intergrown with massive enargite and quartz (Fig. 12C). Barite is a common gangue mineral in the stage 2A assemblage, and it is predominantly concentrated in the distal parts of the deposit (A39 pit). This is similar to barite documented at the Lepanto high-sulfidation deposit (Mankayan, Philippines; Gonzalez, 1959).

\section{$\mathrm{Zn}$-Pb-Au-Ag mineralization (stage 2B)}

Stage $2 \mathrm{~B}$ ore mainly occurs in veins that cut across stage $2 \mathrm{~A}$ mineralization, predominantly within the Western ore zone
(Fig. 11B). The textures of stage $2 \mathrm{~B}$ veins range from massive to colloform, and the mineral assemblages are dominated by $\mathrm{Fe}$ poor sphalerite. Subordinate minerals include galena and pyrite and, to a lesser degree, electrum, tetrahedrite-group minerals, chalcopyrite, bornite, an uncharacterized Zn-In mineral (ideally CuZn $2[\mathrm{In}, \mathrm{Ga}] \mathrm{S}_{4}$; Sahlström et al., 2017b), and barite (Fig. 9 ). Electrum in stage $2 \mathrm{~B}$ occurs as up to $\sim 75-\mu \mathrm{m}$-diameter, anhedral grains intergrown with massive sphalerite, pyrite, and bornite (Fig. 12D). Two types of tetrahedrite-group minerals are present in this stage. The first type occurs as up to $\sim 10-\mu \mathrm{m}$-diameter segregations within galena (Fig. 12E). The second type occurs as up to $\sim 100-\mu \mathrm{m}$-diameter, subhedral crystals intergrown with pyrite, sphalerite, and galena. These crystals are zoned in BSE images, with BSE-bright cores that also contain fine inclusions of galena and oscillatory-zoned rims of BSE-darker material (Fig. 12F).

\section{Cu-Au-Ag mineralization (stage 2C)}

Stage $2 \mathrm{C}$ was a minor event that overprinted stage $2 \mathrm{~B}$ mineralization. Evidence for it has only been observed at a microscopic scale within the Western ore zone (Fig. 12G, H). The mineral assemblage is dominated by massive tennantite, recognized by a greenish color and abundant red internal reflections under the optical microscope. The massive tennantite hosts a variety of subordinate minerals, including luzonite, chalcopyrite, 


\begin{tabular}{|c|c|c|c|c|c|}
\hline क & $\stackrel{3}{\circ} \stackrel{\circ}{-} \stackrel{\circ}{\circ}$ & 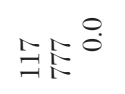 & $\begin{array}{l}\infty \\
\infty \\
\infty \\
\infty\end{array}$ & 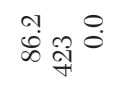 & $\stackrel{\text { L }}{r}$ \\
\hline ت己 & 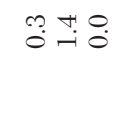 & 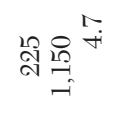 & 药递节 & 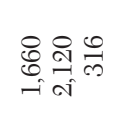 & 串总萗 \\
\hline 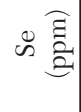 & 范苍苛 & 걱용요 & a & 灾异志 & 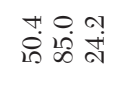 \\
\hline$\oplus$ ڤ્气 & 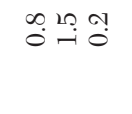 & 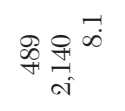 & 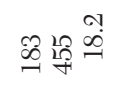 & 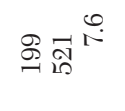 & 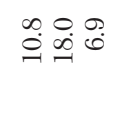 \\
\hline 舫 & 몽 & 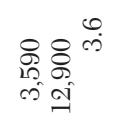 & 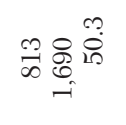 & 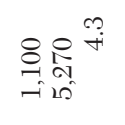 & 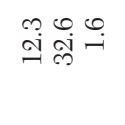 \\
\hline$\Xi \widehat{\underline{a ̆}}$ & $\stackrel{9}{9} \stackrel{20}{\circ} \stackrel{0}{0}:$ & 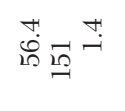 & 它 品 & 点品享 & 宗喿 \\
\hline تَ & 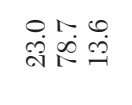 & 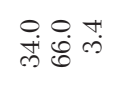 & 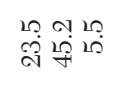 & 范庐 & 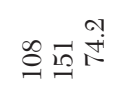 \\
\hline ن & 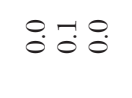 & 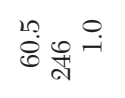 & \& & 눙 ${ }_{0}^{\circ} \stackrel{\circ}{\circ}$ & 옹 \\
\hline क है & ־용 & 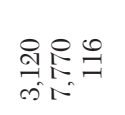 & 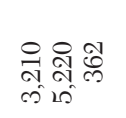 & 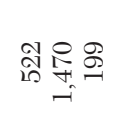 & 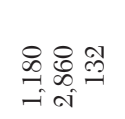 \\
\hline 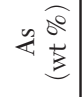 & $8: 8$ & $\begin{array}{l}\text { mo } \\
\text { mat } \\
\text { tio }\end{array}$ & 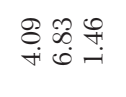 & 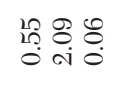 & 궁 ㅇํㅇ \\
\hline 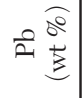 & 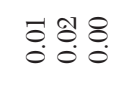 & 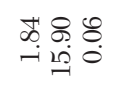 & 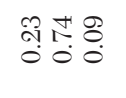 & 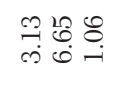 & 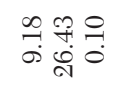 \\
\hline 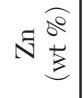 & : & 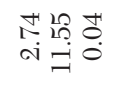 & 정 fำ: & 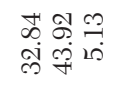 & 象 \\
\hline 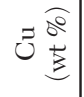 & 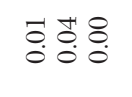 & 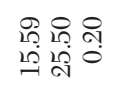 & 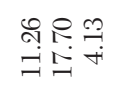 & 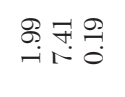 & 동 \\
\hline 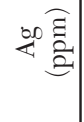 & 공 & 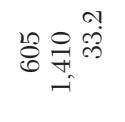 & 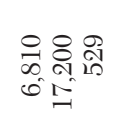 & 般气里 & 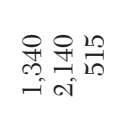 \\
\hline 专言 & 70 & 동 엉 & m: & 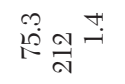 & $\stackrel{\leftrightarrow}{\circ} \stackrel{\leftrightarrow}{-}:$ \\
\hline & 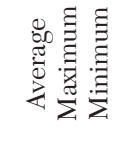 & 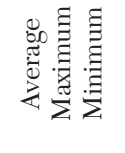 & 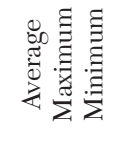 & 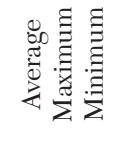 & 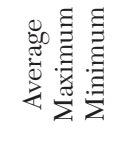 \\
\hline 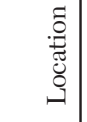 & & 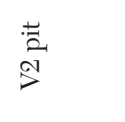 & $\begin{array}{l}\text { 言 } \\
\text { वे }\end{array}$ & $\begin{array}{l}: \\
\stackrel{2}{2} \\
\stackrel{1}{>}\end{array}$ & 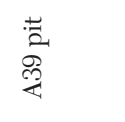 \\
\hline 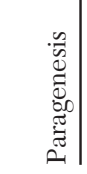 & 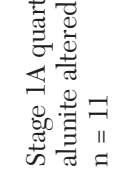 & 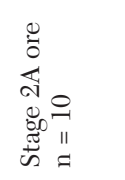 & 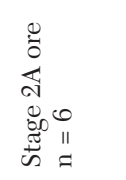 & 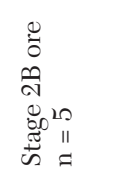 & 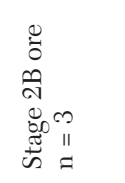 \\
\hline
\end{tabular}

and galena and, to a lesser degree, electrum and aggregates of intergrown hessite $\left(\mathrm{Ag}_{2} \mathrm{Te}\right)$ and petzite $\left(\mathrm{Ag}_{3} \mathrm{AuTe}_{2}\right.$; Fig. 9).

\section{Hydrothermal void fill (stage 3)}

A late stage of dickite and pyrite is widely distributed at Mt. Carlton and has been observed within all three ore zones. The dickite and pyrite generally occur as massive veins or as void fill that overprinted stage $2 \mathrm{~A}, 2 \mathrm{~B}$, and $2 \mathrm{C}$ mineralization (Figs. $9,10 \mathrm{D}, 11 \mathrm{C}, 12 \mathrm{G})$

\section{Supergene oxidation (stage 5)}

Minor supergene oxidation affected the upper $\sim 50 \mathrm{~m}$ of the present-day deposit, with an irregular distribution. Indeed, the discovery outcrop of the Mt. Carlton deposit (Silver Hill) was a gossan developed on veins of stage $2 \mathrm{~A}$ sulfosalt mineralization containing over 1,000 g/t Ag (M. Obiri-Yeboah, pers. commun., 2017). Secondary covellite, chalcocite, and malachite are locally developed on $\mathrm{Cu}$-bearing minerals such as enargite, luzonite, and bornite, particularly along fractures in the minerals (Figs. 11D, 12E). Supergene oxidation is limited at Mt. Carlton ( $1-5 \%$ of total ore), and the vast majority of the metals are hosted in primary and refractory ores.

\section{Sedimentary ore textures}

The structurally controlled veins and hydrothermal breccias that host proximal $\mathrm{Au}-\mathrm{Cu}$ mineralization in the $\mathrm{V} 2$ pit (Fig. $11 \mathrm{~A}, \mathrm{~B}$ ) are texturally distinct from the distal, stratabound Ag mineralization that occurs in the A39 pit and in the southwest corner of the V2 pit. A selection of ore textures from A39 are shown in Figure 13. In Figure 13A, a $\mathrm{D}_{1}$-related fracture that first developed within a silicic altered rhyodacite tuff (unit 4A) has been infilled with hydrothermal sediments made up of finely laminated quartz. Fine particles of pyrite occur within the siliceous sediments, which are interlayered with massive layers of stage 3 dickite and pyrite. Soft-sediment deformation textures were produced as breccia fragments of the wall rock dropped into the open fracture zone as it was being infilled.

Figure 13B shows a similar fracture within unit $4 \mathrm{~A}$ that has been infilled with a complex sequence of detrital sediments. The sediments preserve graded bedding and comprise beds of finely laminated siltstone, as well as coarser sandstone beds that are made up of igneous quartz crystals, rhyodacite fragments, and pyrite. Several steep, synsedimentary normal faults can be observed within the laminated siltstone in the lower part of the fracture opening. Soft-sediment deformation textures were produced by coarse fragments of the rhyodacite wall rock that dropped into the open fracture during infill. The sedimentary sequence was at one point infiltrated by a hydrothermal fluid, and the paleofluid channel can be seen cutting across the laminated sediments in the lower part of the fracture cavity. The hydrothermal fluid migrated vertically through the sediments, likely within one of the steep normal faults, and then dispersed laterally when it intersected a thick layer of sandstone. The fluid disturbed this sandstone layer as well as the overlying siltstone beds, which created a distinct topography within the fracture. Some quartz and pyrite crystals in the sandstone layer can be seen to have dropped down through the fluid channel and accumulated at the base of the open fracture. Subsequently, younger beds of siltstone and sandstone progressively draped the topography that was 

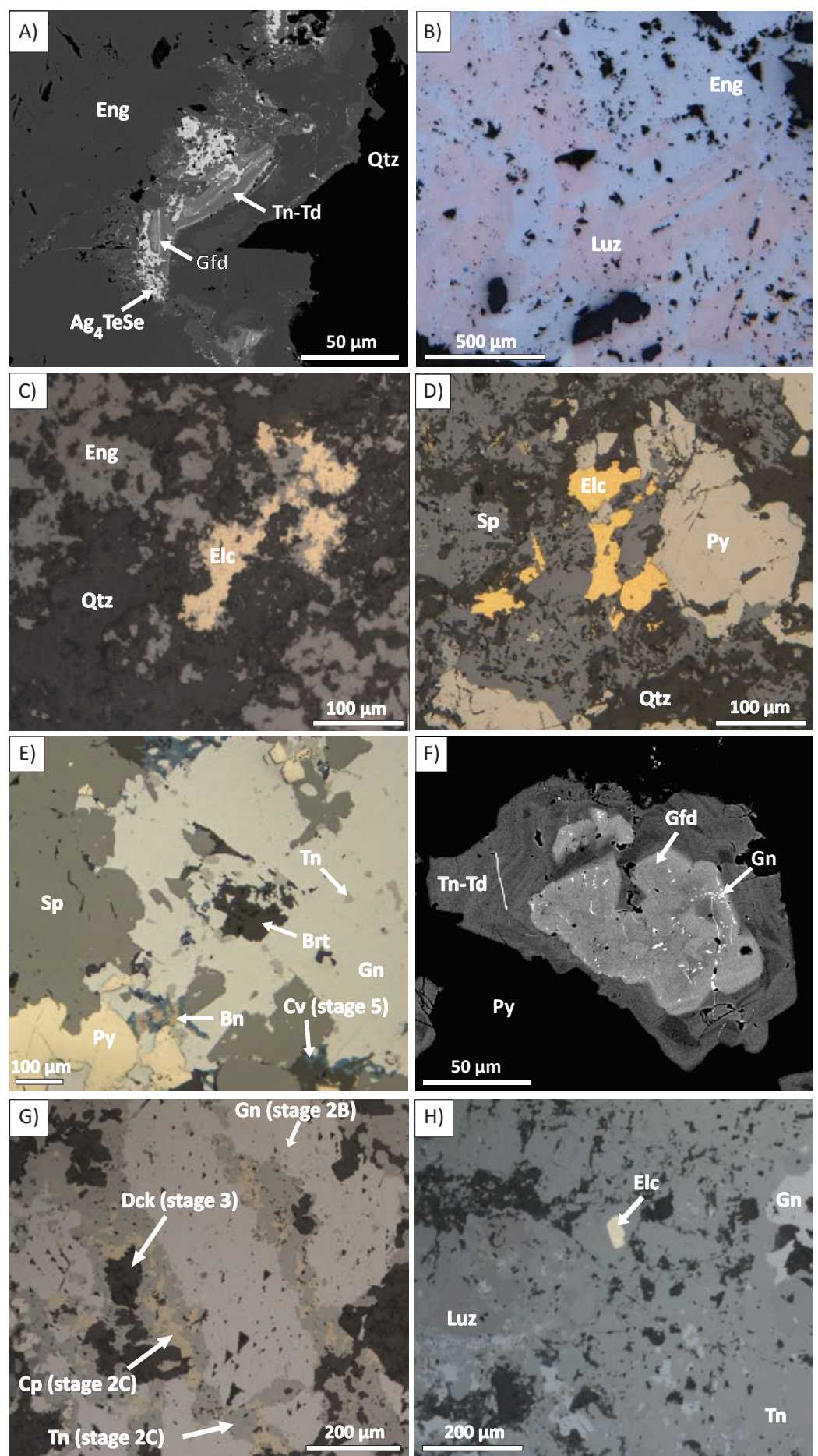

Fig. 12. Images of selected ore mineral associations at Mt. Carlton. (A) Stage 2A assemblage containing zoned crystals made up of alternating bands of goldfieldite and tennantite-tetrahedrite. The tetrahedrite-group minerals have been overprinted first by $\mathrm{Ag}_{4} \mathrm{TeSe}$ and then by enargite (BSE image). (B) Intergrown enargite and luzonite in stage 2A ore (reflected light, plane polarized). (C) Electrum intergrown with enargite and quartz in stage 2A ore (reflected light, plane polarized). (D) Electrum intergrown with sphalerite and pyrite in stage $2 \mathrm{~B}$ ore (reflected light, plane polarized). (E) Intergrown sphalerite, pyrite, galena, bornite, and barite in stage $2 \mathrm{~B}$ ore. The galena contains abundant segregations of tennantite, and supergene covellite (stage 5) has overprinted the assemblage (reflected light, plane polarized). (F) Zoned crystal of tetrahedrite-group minerals occurring intergrown with pyrite in stage $2 \mathrm{~B}$ assemblage. The crystal has a core of goldfieldite with inclusions of galena and a rim of oscillatory-zoned tennantite-tetrahedrite (BSE image). (G) Stage 2B galena crystal overprinted first by stage $2 \mathrm{C}$ tennantite and chalcopyrite, and then by stage 3 dickite (reflected light, plane polarized). (H) Stage 2C assemblage with massive tennantite hosting electrum, galena, and luzonite (reflected light, plane polarized light). Mineral abbreviations (Kretz, 1983): $\mathrm{Bn}=$ bornite, $\mathrm{Brt}=$ barite, $\mathrm{Cp}=$ chalcopyrite, $\mathrm{Cv}=$ covellite, $\mathrm{Dck}=$ dickite, Elc = electrum, Eng = enargite, $\mathrm{Gfd}=$ goldfieldite, $\mathrm{Gn}=$ galena, $\mathrm{Luz}=$ luzonite, $\mathrm{Py}=$ pyrite, $\mathrm{Qtz}=$ quartz, $\mathrm{Sp}=$ sphalerite, $\mathrm{Td}=$ tetrahedrite, $\mathrm{Tn}=$ tennantite. 

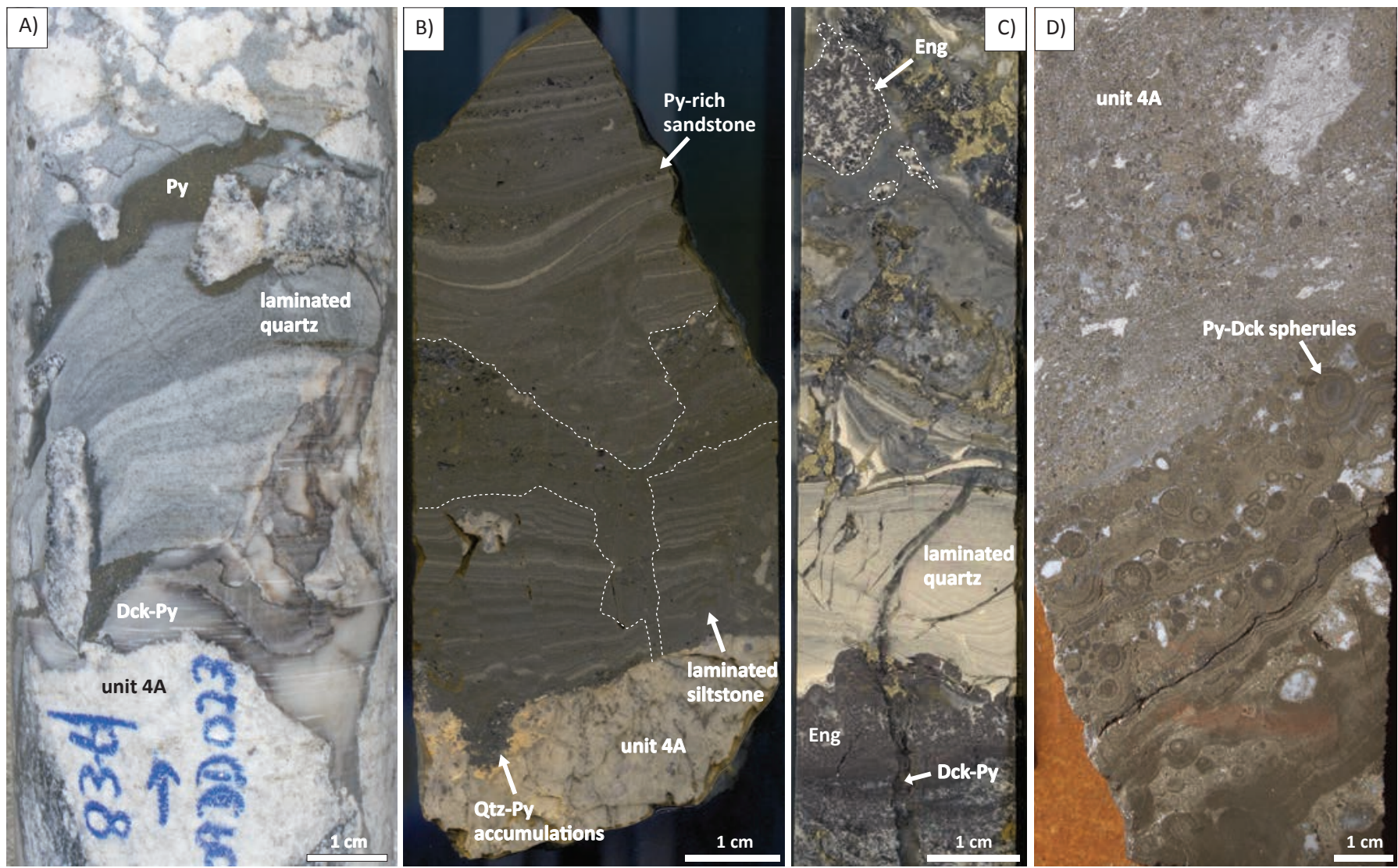

Fig. 13. Photographs of sedimentary ore textures from the A39 pit at Mt. Carlton (see text for detailed descriptions). (A) A fracture cavity developed within a silicic altered rhyodacite tuff (unit 4A) has been infilled with hydrothermal sediments made up of finely laminated quartz, which occur interlayered with massive stage 3 dickite and pyrite. Note the soft-sediment deformation textures caused by wall-rock clasts that dropped into the sediments as the open fracture was being infilled. (B) Detrital sediments infilling a fracture within unit 4A. The sediments show a graded bedding and comprise finely laminated siltstone beds and pyrite-rich sandstone beds. Synsedimentary normal faults and soft-sediment deformation textures are visible within the laminated siltstone in the lower part of the fracture cavity. A hydrothermal fluid has infiltrated and disturbed the sediments (indicated in stippled lines). Note the quartz and pyrite crystals that have dropped down through the fluid channel and accumulated at the bottom of the open fracture. Younger sediments deposited within the fracture have progressively draped the topography that was produced by the fluid. (C) Stage 2A enargite mineralization infilling a fracture cavity has been covered by and remobilized into siliceous sediments, prior to being crosscut by stage 3 dickite-pyrite veinlets. (D) Spherules made up of concentric rings of fibrous and radial stage 3 pyrite and dickite, which occur as discrete layers within a volcanolacustrine sediment (unit 4A). Mineral abbreviations (Kretz, 1983): Dck = dickite, Eng = enargite, Py = pyrite, Qtz = quartz.

created by the hydrothermal fluid, as the open cavity along the fracture was infilled with sediment.

The fracture shown in Figure 13C contains three distinct sedimentary domains. The basal infill within the fracture is predominantly made up of stage $2 \mathrm{~A}$ enargite mineralization, along with minor amounts of quartz. The enargite-rich layer is overlain by light-colored siliceous sediments, which exhibit intricate cross-laminations. Soft-sediment deformation textures are visible along the contact between the two lavers. The laminated siliceous sediments are, in turn, overlain by darkercolored quartz sediments that lack laminations. Clasts of enargite ore have been remobilized into these sediments, and the entire sedimentary sequence was subsequently crosscut and brecciated by younger veinlets of stage 3 dickite and pyrite.

Figure 13D shows coarse-grained spherules, made up of concentric rings of fibrous and radial stage 3 pyrite and dickite, which form layers within a volcanolacustrine sediment (unit 4A). Equivalent but finer-grained pyrite-dickite spherules have been observed occurring as infill within restricted open spaces in fractures.

Overall, the four examples shown in Figure 13 highlight how metal deposition in A39 occurred partly contemporaneously with sedimentation and deformation. The significance of these sedimentary textures with respect to the potential of the hydrothermal system to reach the paleosurface at the time of mineralization is discussed below.

\section{Mineral Chemistry}

The major element compositions of $\mathrm{Cu}$ sulfosalts, electrum, alunite, and APS minerals were analyzed by wavelength dispersive X-ray spectrometry (WDS). The analyses were carried out using a JEOL JXA8200 Superprobe housed at the Advanced Analytical Centre (AAC) at James Cook University (see Digital Appendix 1 for details on analytical conditions).

Analysis of the SWIR spectra of alunite provides an alternative method to estimate the composition of the mineral (Chang 
et al., 2011). Specifically, the wavelength position of the absorption peak at $\sim 1,480 \mathrm{~nm}$ (range 1,478-1,495 nm) in the alunite SWIR spectra will vary depending on the $\mathrm{Na} /(\mathrm{Ka}+\mathrm{Na})$ mole ratio. An increasing $\mathrm{Na} /(\mathrm{Ka}+\mathrm{Na})$ ratio in alunite will shift the peak to the higher wavelength positions (Chang et al., 2011). For quantitative analysis of SWIR spectra of alunite from Mt. Carlton, only data from the Evolution database (TerraSpec) were used. This was to avoid potential interinstrument variability between the TerraSpec and PIMA devices (Chang and Yang, 2012). It should be noted that the TerraSpec data do not differentiate between disseminated alunite and vein alunite.

\section{Enargite and luzonite}

Enargite (orthorhombic) and luzonite (tetragonal) are dimorphs with the ideal formula $\mathrm{Cu}_{3} \mathrm{AsS}_{4}$. Luzonite forms a complete solid solution series with famatinite (tetragonal $\mathrm{Cu}_{3} \mathrm{SbS}_{4}$ ), whereas enargite generally only incorporates up to 20 mole \% Sb (Springer, 1969). Analyzed enargite grains from stage $2 \mathrm{~A}$ contain up to 18 mole $\% \mathrm{Sb}$ (Fig. 14A, Table 2). Luzonite from the same stage contains up to 49 mole $\%$ $\mathrm{Sb}$ - evidence for extensive solid solution toward famatinite. Luzonite from stage $2 \mathrm{C}$ has a narrower compositional range and contains up to 30 mole \% Sb. Enargite and luzonite carry significant amounts of $\mathrm{Ag}$, with a maximum content of 1.07 wt $\% \mathrm{Ag}$ for stage $2 \mathrm{~A}$ enargite, $0.27 \mathrm{wt} \% \mathrm{Ag}$ for stage $2 \mathrm{~A}$ luzonite, and 0.16 wt \% Ag for stage 2C luzonite (Table 2).

\section{Tetrahedrite-group minerals}

The tetrahedrite-group minerals have a simplified isometric formula of $\mathrm{A}_{12} \mathrm{D}_{4} \mathrm{X}_{13}$, where $\mathrm{A}=\mathrm{Cu}, \mathrm{Ag}, \mathrm{Zn}, \mathrm{Fe}, \mathrm{Cd}, \mathrm{Mn}, \mathrm{Hg}$; $\mathrm{D}=\mathrm{As}, \mathrm{Sb}, \mathrm{Te}, \mathrm{Bi}$; and $\mathrm{X}=\mathrm{S}$, Se (Johnson et al., 1986). The analyzed compositions from Mt. Carlton predominantly vary between the end-members tennantite $\left(\mathrm{Cu}_{10}[\mathrm{Fe}, \mathrm{Zn}]_{2} \mathrm{As}_{4} \mathrm{~S}_{13}\right)$, tetrahedrite $\left(\mathrm{Cu}_{10}[\mathrm{Fe}, \mathrm{Zn}]_{2} \mathrm{Sb}_{4} \mathrm{~S}_{13}\right)$, and goldfieldite $\left(\mathrm{Cu}_{10}\right.$ $\mathrm{Te}_{4} \mathrm{~S}_{13} ;$ Fig. 14B, Table 2).

The zoned crystals in the stage $2 \mathrm{~A}$ assemblage (Fig. 12A) have bimodal compositions. The BSE-bright bands have goldfieldite-dominated compositions, whereas the BSE-dark bands have compositions intermediate between tennantite and tetrahedrite (Fig. 14B, Table 2). The two types of tetrahedrite-group minerals in the stage $2 \mathrm{~B}$ assemblage show distinct chemical compositions. The first type, which occurs as segregations in galena (Fig. 12E), has compositions corresponding to Te-rich tennantite (Fig. 14B, Table 2). In the zoned crystals (Fig. 12F), the cores have goldfieldite-dominated compositions, whereas the oscillatory-zoned rims have variable compositions ranging from tetrahedrite to Te-rich tennantite (Fig. 14B, Table 2). The optical identification of tennantite in the stage $2 \mathrm{C}$ assemblage has been confirmed by WDS analyses that show tennantite-dominated compositions for this mineral (Fig. 14B, Table 2). Tennantite and tetrahedrite from Mt. Carlton have a high $\mathrm{Zn}$ content in the A site (up to $8.03,8.21$, and 10.73 wt $\% \mathrm{Zn}$ for stage $2 \mathrm{~A}, 2 \mathrm{~B}$, and $2 \mathrm{C}$, respectively). Owing to stoichiometry, the $\mathrm{Zn}$ content in goldfieldite is much lower. The maximum Ag content in tetrahedrite-group minerals from Mt. Carlton correspond to 1.18, 0.93 , and $1.17 \mathrm{wt} \% \mathrm{Ag}$ for stage $2 \mathrm{~A}, 2 \mathrm{~B}$, and $2 \mathrm{C}$ mineralization, respectively (Table 2).

\section{Electrum}

Electrum (Au-Ag alloy) from Mt. Carlton shows similar compositions in all three ore stages (Fig. 14C, Table 2). The electrum is Au dominated, with Au contents in the ranges of 74 to 89, 66 to 96 , and 72 to 73 mole $\%$ for stage $2 \mathrm{~A}, 2 \mathrm{~B}$, and $2 \mathrm{C}$ mineralization, respectively. The abundance of electrum throughout the paragenetic sequence, combined with the high Au content in the mineral, suggest that it is an important Au carrier in the ores at Mt. Carlton. However, laser ablation-inductively coupled plasma-mass spectrometry (LA-ICP-MS) trace element analyses have revealed that significant Au concentrations also occur in common sulfide and sulfosalt minerals such as pyrite (up to $367 \mathrm{ppm}$ ), enargite (up to $62 \mathrm{ppm}$ ), and sphalerite (up to 75 ppm; Sahlström et al., 2017a). As of September 2017, about $18 \%$ of the total Au at Mt. Carlton is recovered in a gravity circuit, with the remainder being recovered via flotation techniques (M. Obiri-Yeboah, pers. commun., 2017).

\section{Alunite and APS minerals}

Disseminated alunite at Mt. Carlton occurs as platy euhedral crystals up to $\sim 300 \mu \mathrm{m}$ long, typically in aggregates (Fig. $15 \mathrm{~A}-\mathrm{C})$. In BSE images the alunite crystals generally appear

Table 2. Analyzed Compositional Ranges of Cu Sulfosalts and Electrum from Different Paragenetic Stages at Mt. Carlton

\begin{tabular}{|c|c|c|}
\hline Paragenetic stage & Mineral & Analyzed compositional range \\
\hline $\begin{array}{l}\text { Stage } 2 \mathrm{~A} \\
\text { Stage } 2 \mathrm{~A} \\
\text { Stage } 2 \mathrm{~A} \\
\text { Stage } 2 \mathrm{~A} \\
\text { Stage } 2 \mathrm{~A}\end{array}$ & $\begin{array}{l}\text { Enargite }(\mathrm{n}=31) \\
\text { Luzonite }(\mathrm{n}=31) \\
\text { Goldfieldite }(\mathrm{n}=14) \\
\text { Tennantite-tetrahedrite }(\mathrm{n}=21) \\
\text { Electrum }(\mathrm{n}=105)\end{array}$ & $\begin{array}{l}\left(\mathrm{Cu}_{3.04-3.19} \mathrm{Ag}_{0.00-0.04} \mathrm{Zn}_{0.00-0.01} \mathrm{Fe}_{0.00-0.01}\right)\left(\mathrm{As}_{0.81-1.01} \mathrm{Sb}_{0.00-0.18}\right) \mathrm{S}_{4.00} \\
\left(\mathrm{Cu}_{3.07-3.24} \mathrm{Fe}_{0.00-0.03} \mathrm{Zn}_{0.00-0.02} \mathrm{Ag}_{0.00-0.01}\right)\left(\mathrm{As}_{0.47-1.00} \mathrm{Sb}_{0.00-0.49}\right) \mathrm{S}_{4.00} \\
\left(\mathrm{Cu}_{11.35-12.01} \mathrm{Ag}_{0.01-0.18} \mathrm{Zn}_{0.00-0.05} \mathrm{Fe}_{0.00-0.03}\right)\left(\mathrm{Te}_{2.16-3.07} \mathrm{As}_{0.59-1.48} \mathrm{Sb}_{0.21-0.49}\right) \mathrm{S}_{12.57-12.86} \\
\left(\mathrm{Cu}_{10.22-10.61} \mathrm{Zn}_{1.65-1.97} \mathrm{Fe}_{0.00-0.26} \mathrm{Ag}_{0.02-0.05}\right)\left(\mathrm{As}_{1.41-2.55} \mathrm{Sb}_{1.07-2.54} \mathrm{Te}_{0.00-0.02}\right) \mathrm{S}_{12.53-13.05} \\
\mathrm{Au}_{0.74-0.89} \mathrm{Ag}_{0.10-0.24} \mathrm{Cu}_{0.00-0.09}\end{array}$ \\
\hline $\begin{array}{l}\text { Stage } 2 B \\
\text { Stage } 2 B \\
\text { Stage } 2 B \\
\text { Stage } 2 B\end{array}$ & $\begin{array}{l}\text { Tennantite }^{1}(\mathrm{n}=21) \\
\text { Goldfieldite }^{2}(\mathrm{n}=4) \\
\text { Tennantite-tetrahedrite }^{2} \quad(\mathrm{n}=23) \\
\text { Electrum }(\mathrm{n}=196)\end{array}$ & $\begin{array}{l}\left(\mathrm{Cu}_{11.05-11.47} \mathrm{Zn}_{0.63-1.03} \mathrm{Fe}_{0.00-0.21} \mathrm{Ag}_{0.01-0.03}\right)\left(\mathrm{As}_{2.12-2.65} \mathrm{Te}_{0.88-1.27} \mathrm{Sb}_{0.48-0.61}\right) \mathrm{S}_{12.76-13.02} \\
\left(\mathrm{Cu}_{11.45-11.78} \mathrm{Zn}_{0.09-0.43} \mathrm{Ag}_{0.07-0.14} \mathrm{Fe}_{0.01-0.10}\right)\left(\mathrm{Te}_{2.05-2.33} \mathrm{As}_{0.70-1.03} \mathrm{Sb}_{0.47-0.67}\right) \mathrm{S}_{12.75-12.88} \\
\left(\mathrm{Cu}_{10.14-11.70} \mathrm{Zn}_{0.59-2.00} \mathrm{Fe}_{0.01-0.20} \mathrm{Ag}_{0.03-0.08}\right)\left(\mathrm{Sb}_{0.88-2.47} \mathrm{As}_{1.39-2.15} \mathrm{Te}_{0.01-1.31}\right) \mathrm{S}_{12.68-12.97} \\
\mathrm{Au}_{0.66-0.96} \mathrm{Ag}_{0.04-0.33} \mathrm{Cu}_{0.00-0.05}\end{array}$ \\
\hline $\begin{array}{l}\text { Stage } 2 \mathrm{C} \\
\text { Stage } 2 \mathrm{C} \\
\text { Stage } 2 \mathrm{C}\end{array}$ & $\begin{array}{l}\text { Tennantite }(\mathrm{n}=47) \\
\text { Luzonite }(\mathrm{n}=30) \\
\text { Electrum }(\mathrm{n}=2)\end{array}$ & $\begin{array}{l}\left(\mathrm{Cu}_{9.60-10.93} \mathrm{Zn}_{0.61-2.45} \mathrm{Fe}_{0.01-0.65} \mathrm{Ag}_{0.01-0.16}\right)\left(\mathrm{As}_{2.61-3.90} \mathrm{Sb}_{0.05-1.05} \mathrm{Te}_{0.00-0.02}\right) \mathrm{S}_{12.35-13.80} \\
\left(\mathrm{Cu}_{3.05-3.29} \mathrm{Zn}_{0.00-0.06} \mathrm{Fe}_{0.00-0.02} \mathrm{Ag}_{0.00-0.01}\right)\left(\mathrm{As}_{0.70-1.02} \mathrm{Sb}_{0.00-0.31}\right) \mathrm{S}_{4.00} \\
\mathrm{Au}_{0.72-0.73} \mathrm{Ag}_{0.24-0.25} \mathrm{Cu}_{0.03}\end{array}$ \\
\hline
\end{tabular}

\footnotetext{
${ }^{1}$ Segregations in galena

${ }^{2}$ Zoned crystals
} 

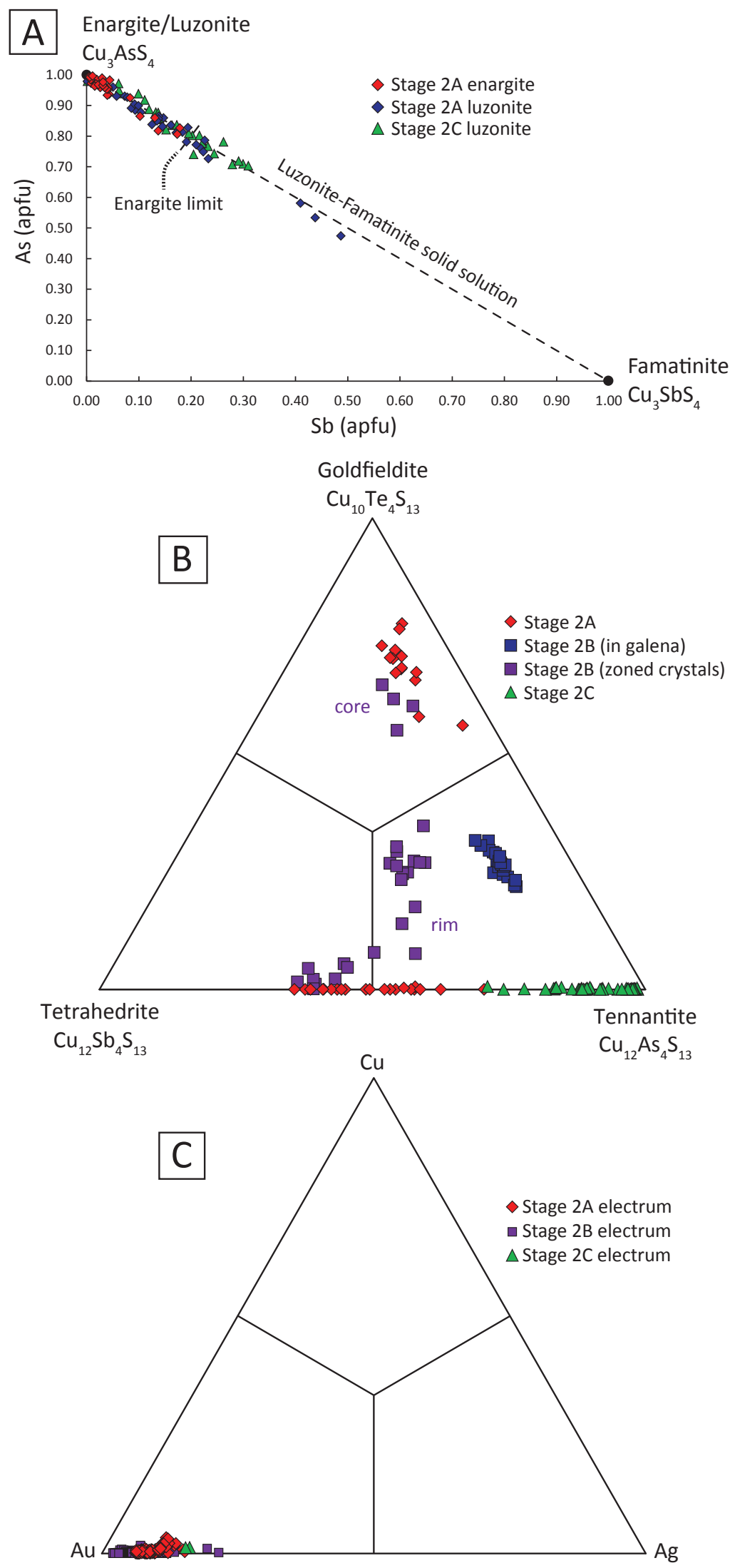

Fig. 14. Compositional plots of ore minerals from Mt. Carlton. (A) Enargite and luzonite. (B) Tetrahedrite-group minerals. (C) Electrum. 

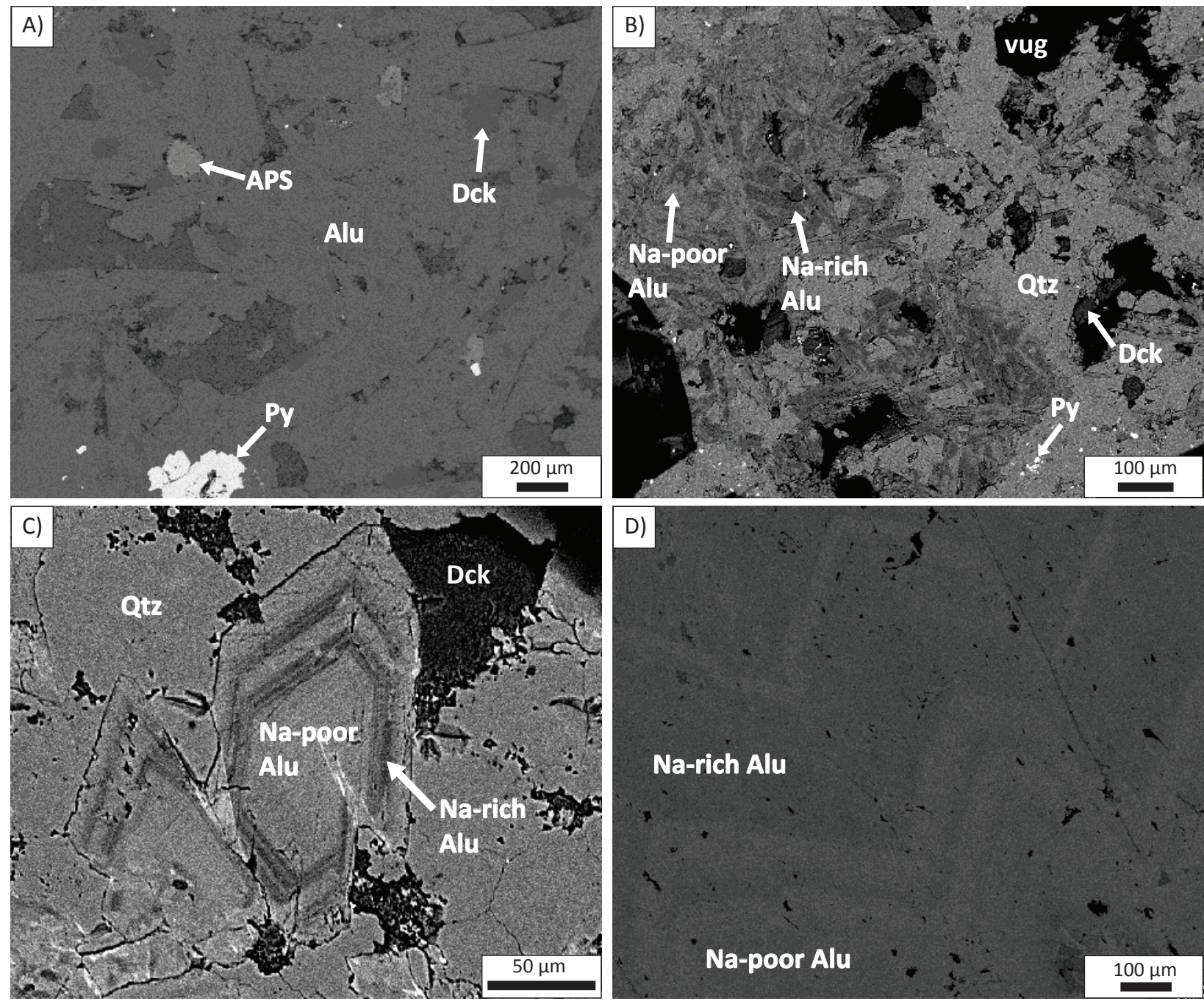

Natroalunite

$\mathrm{NaAl}_{3}\left(\mathrm{SO}_{4}\right)_{2}(\mathrm{OH})_{6}$

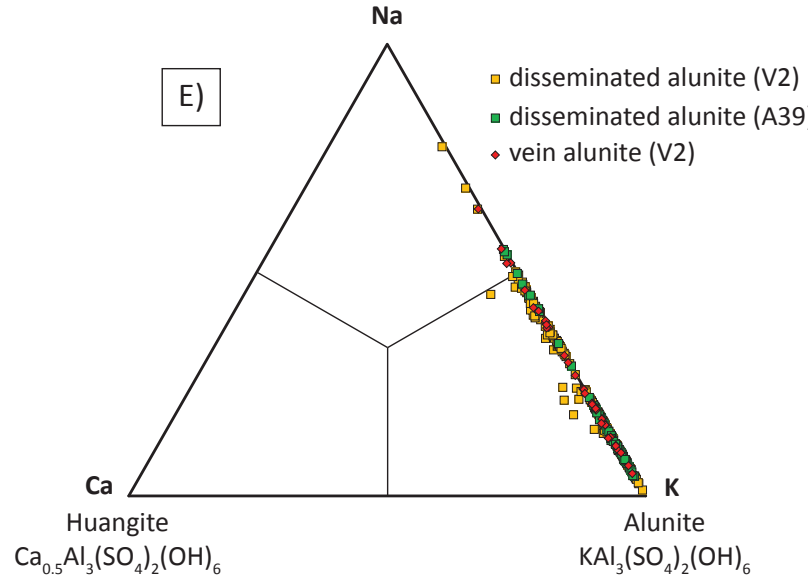

Alunite, natroalunite $(\mathrm{K}, \mathrm{Na}) \mathrm{Al}_{3}\left(\mathrm{SO}_{4}\right)_{2}(\mathrm{OH})_{6}$

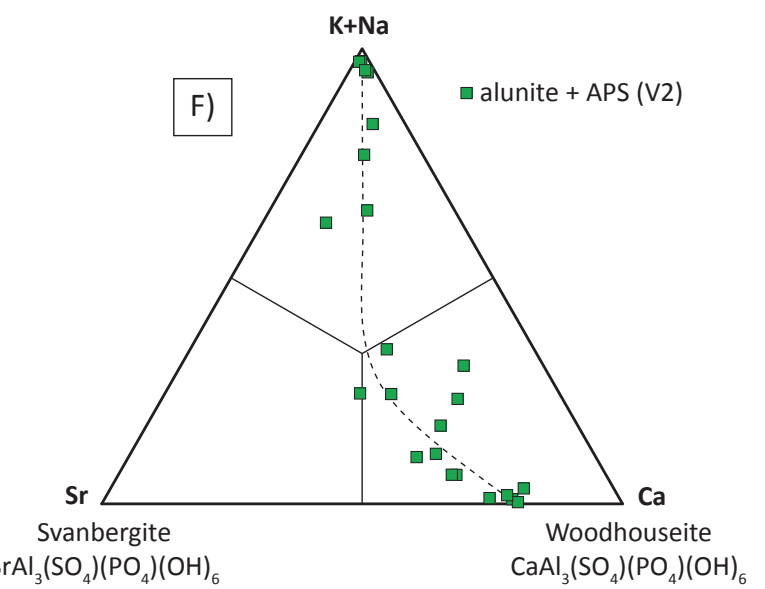

Fig. 15. Images and compositional plots of alunite and aluminum-phosphate-sulfate (APS) minerals from Mt. Carlton. (A) Disseminated alunite from V2, locally with cores of APS minerals, coexisting with dickite and pyrite (BSE image). (B) Disseminated alunite from V2, showing a patchy zoning related to Na and K content (BSE image). (C) Disseminated alunite from A39, showing an oscillatory zoning related to Na and K content (BSE image). (D) Alunite vein from V2, showing a sawtooth compositional banding related to Na and K content (BSE image). (E) Compositional plot of alunite from Mt. Carlton. (F) Compositional plot of mixed analyses of alunite and APS minerals from Mt. Carlton. Mineral abbreviations (Kretz, 1983): $\mathrm{Alu}=$ alunite, $\mathrm{Dck}=$ dickite, $\mathrm{Py}=$ pyrite, $\mathrm{Qtz}=$ quartz. 
homogeneous (Fig. 15A) or have a patchy to oscillatory zonation (Fig. 15B, C); the latter is mainly due to variations in $\mathrm{Na}$ and $\mathrm{K}$ content. Some alunite grains from V2 contain cores of APS minerals (Fig. 15A), which were not observed in alunite grains from A39. The vein alunite shows a distinct saw-tooth compositional banding oriented parallel to the vein orientation in BSE images (Fig. 15D), again mainly due to variations in $\mathrm{Na}$ and $\mathrm{K}$ content.

Analyzed disseminated alunite and vein alunite both exhibit compositions within the alunite-natroalunite solid solution (trigonal $\mathrm{KAl}_{3}\left[\mathrm{SO}_{4}\right]_{2}[\mathrm{OH}]_{6}-\mathrm{NaAl}_{3}\left[\mathrm{SO}_{4}\right]_{2}[\mathrm{OH}]_{6}$ ), and they are low in $\mathrm{Ca}(\mathrm{Ca} /[\mathrm{K}+\mathrm{Na}+\mathrm{Ca}]<0.1$; Fig. $15 \mathrm{E})$. Many analyses are dominated by $\mathrm{K}$, with only a minority of the analyses plotting in the natroalunite field (Fig. 15E). Since WDS analysis of alunite-group minerals requires a large beam size (e.g., $15 \mu \mathrm{m}$; Deyell et al., 2005b), we were not able to analyze APS minerals directly. The compositions shown in Figure $15 \mathrm{~F}$ represent mixed analyses of alunite and APS minerals. The data indicate a trend from alunite/natroalunite toward compositions within the woodhouseite-svanbergite solid solution (trigonal $\mathrm{CaAl}_{3}\left[\mathrm{SO}_{4}\right]\left[\mathrm{PO}_{4}\right][\mathrm{OH}]_{6}-\mathrm{SrAl}_{3}\left[\mathrm{SO}_{4}\right]\left[\mathrm{PO}_{4}\right][\mathrm{OH}]_{6}$ ), with woodhouseite dominating over svanbergite.

The SWIR data for Mt. Carlton show that the $~ 1,480-\mathrm{nm}$ absorption peak in alunite spectra occur in the wavelength range of 1,478 to $1,485 \mathrm{~nm}$ for most of the data (Fig. 16). This suggests that the alunite has K-dominated compositions, which corroborates the results from the WDS analyses. Furthermore, the SWIR data for alunite show a spatial zonation across the area around the open pits. The $\sim 1,480$-nm peak is shifted to the higher-wavelength positions-i.e., the alunite is increasingly Na rich - to the northeast (Fig. 16).

\section{${ }^{40} \mathrm{Ar} /{ }^{39} \mathrm{Ar}$ Geochronology}

Alunite formed during hydrothermal alteration at Mt. Carlton was dated using ${ }^{40} \mathrm{Ar} / 39 \mathrm{Ar}$ geochronology. Optically pure mineral separates (110-300- $\mu$ m-diameter crystals) of disseminated alunite (stage 1A; Fig. 9) and vein alunite (stage 1B) from the V2 and A39 pits were handpicked from crushed samples under a stereomicroscope. The alunite separates were irradiated with fast neutrons at the McMaster Nuclear Reactor at McMaster University, Canada, and subsequently analyzed for ${ }^{40} \mathrm{Ar} /{ }^{39} \mathrm{Ar}$ at the Argon Geochronology Laboratory at the University of Michigan, USA. The samples were step-heated using a continuous 5-W Ar-ion laser and Ar isotopes were measured in a VG$1200 \mathrm{~S}$ mass spectrometer, following the procedure described in Frey et al. (2007) and Rooney et al. (2013).

Calculated final ages from ${ }^{40} \mathrm{Ar} / 39 \mathrm{Ar}$ spectra of disseminated alunite $(\mathrm{n}=4$, using $2 \sigma$ for error) are $277.4 \pm$ $5.8 \mathrm{Ma}$ for sample HC07RCD300-136, $276.9 \pm 6.5 \mathrm{Ma}$ for sample HC09DD023-112, 279.3 \pm 6.9 Ma for sample HC14DD1133-178, and 265.1 \pm 6.6 for sample MCR024D-177 (Table 3, Appendix 1). Calculated final ages for vein alunite $(\mathrm{n}=$ 2) are $284.3 \pm 6.0 \mathrm{Ma}$ for sample MCR024D-148 and 284.2 \pm 7.0 Ma for sample HC09DD037-34 (Table 3, Appendix 1).

\section{Discussion}

\section{Deposit classification}

The alteration mineralogy (e.g., alunite, dickite, kaolinite, pyrophyllite, APS minerals) as well as the alteration zonation (silicic core $\rightarrow$ quartz-alunite $\rightarrow$ quartz-dickite-kaolinite) at Mt. Carlton are consistent with highly acidic hydrothermal fluids leaching the volcanic host rocks, with decreasing intensity away from the fluid conduits. These features are characteristic of high-sulfidation deposits worldwide (e.g., Steven and Ratté, 1960; Stoffregen, 1987; Arribas, 1995a). The highsulfidation-state ore mineral assemblage dominated by enargite further supports the interpretation that Mt. Carlton is a high-sulfidation epithermal deposit (e.g., Hedenquist, 1987; Sillitoe, 1993; Hedenquist and Lowenstern, 1994; Arribas, 1995a; Einaudi et al., 2003). This identification has implications for exploration in the district, as Mt. Carlton is likely to have formed as part of a larger magmatic-hydrothermal mineralizing system, centered on an underlying porphyry intrusion that could be mineralized with $\mathrm{Cu}, \mathrm{Au}$, and/or Mo (Arribas et al., 1995b; Hedenquist et al., 1998; Sillitoe, 2010; Chang et al., 2011).

\section{Age of the Mt. Carlton deposit}

The U-Pb zircon ages of the volcanic rocks that host mineralization (unit 3, $281 \pm 4$ to $277 \pm 3 \mathrm{Ma}$; I. Corral, unpub. data, 2018) and of those that crosscut mineralization (unit 9; $266 \pm 3 \mathrm{Ma}$; I. Corral, unpub. data, 2018) provide upper and lower constraints on the age of the Mt. Carlton deposit. The age range yielded from ${ }^{40} \mathrm{Ar} /{ }^{39} \mathrm{Ar}$ spectra of five out of the six dated alunite separates $(284 \pm 7$ to $277 \pm 7 \mathrm{Ma}$; Table 3) overlaps within error with the U-Pb zircon age of unit 3. These results suggest that hydrothermal alteration and epithermal mineralization at Mt. Carlton occurred shortly (no more than 7 m.y.) after the formation of the volcanic host rocks. This is a common feature in many documented highsulfidation deposits (Arribas, 1995a) and confirms the geologic observations that link the formation of the Mt. Carlton deposit to the Early Permian back-arc rifting stage in the Bowen Basin. The youngest, outlier alunite age at $265 \mathrm{Ma}$ overlaps within error with the U-Pb zircon age of unit 9 , and these two dated samples were collected close to each other $(<100 \mathrm{~m}$ apart). This may suggest that the emplacement of unit 9 represented a later heating event that formed or reset alunite locally, possibly along veinlets that are not visible in the strongly altered rocks (e.g., Arribas et al., 2011).

\section{Origin of alunite and implications for exploration}

For exploration purposes, it is important to determine the origin of advanced argillic alteration in epithermal deposits, as the spatial relationship between precious and base metal mineralization and advanced argillic assemblages varies with the origin of the alteration (Sillitoe, 1993; Hedenquist et al., 2000). As the key mineral for understanding the origin of advanced argillic alteration, a distinction should be made between alunite formed from hypogene vapors and vapor condensates (magmatic-steam alunite and magmatichydrothermal alunite, respectively), and alunite formed from near-surface geothermal and secondary oxidation processes (steam-heated alunite and supergene alunite, respectively; Rye et al., 1992).

The coarse grain size, platy crystal habit, local $\mathrm{Na}$ enrichment, and presence of inner cores of APS minerals observed for disseminated alunite at Mt. Carlton point toward a magmatic-hydrothermal origin (Stoffregen and Alpers, 1987; Rye 


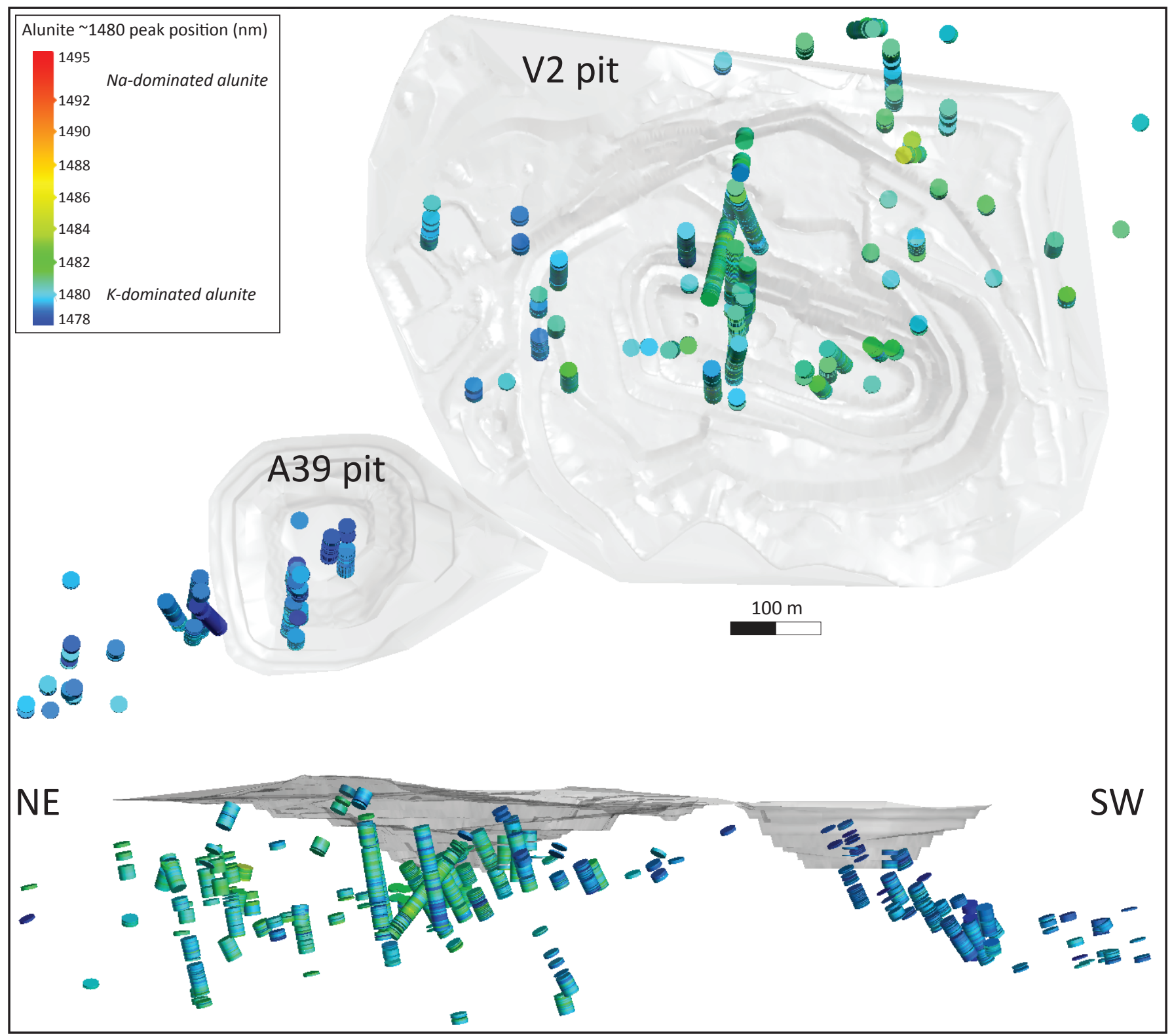

Fig. 16. Leapfrog 3-D model showing the wavelength positions of the $~ 1,480$-nm absorption peak in SWIR spectra of alunite across the Mt. Carlton deposit.

et al., 1992; Aoki et al., 1993; Arribas et al., 1995a; Itaya et al., 1996; Deyell et al., 2005a, b; Rye, 2005). Alunite of steamheated and supergene origins instead tends to occur as porcellaneous masses of fine-grained rhombohedral (pseudocubic) crystals that lack enrichment in $\mathrm{Na}$ (Stoffregen and Alpers, 1987; Hedenquist et al., 2000; Deyell et al., 2005a, b). The coarse-grained, plumose, monomineralic, and compositionally banded alunite present in veins at Mt. Carlton shows a close textural resemblance to the type example of magmaticsteam alunite from Marysvale, Utah (Cunningham et al., 1984; Rye et al., 1992; Rye, 2005). The sulfur isotope systematics of disseminated alunite (positive $\delta^{34} \mathrm{~S}$ values in alunite, negative $\delta^{34} \mathrm{~S}$ values in coexisting pyrite; Sahlström et al., 2016) and alunite veins $\left(\delta^{34} \mathrm{~S}\right.$ values close to the total sulfur composition; Sahlström et al., 2016) further support the identification of magmatic-hydrothermal and magmatic-steam origins, respectively.

Based on the evidence from alunite, acidic hydrothermal solutions formed by the condensation of a long-standing and slowly rising magmatic vapor plume are inferred to have interacted with the volcanic host rocks to produce the laterally extensive alteration halo surrounding the Mt. Carlton deposit (e.g., Rye et al., 1992; Rye, 2005; Hedenquist and Taran, 2013). Pulses of rapidly ascending magmatic steam from the degassing magma sporadically punctuated the deposit, producing veins of magmatic-steam alunite (e.g., Rye et al., 1992; Rye, 2005). At Mt. Carlton, magmatic-steam alunite is largely confined to the high-grade $\mathrm{D}_{1}$ feeder structures. Magmaticsteam alunite has only been documented in a limited number of high-sulfidation deposits globally (Rye, 2005). However, 


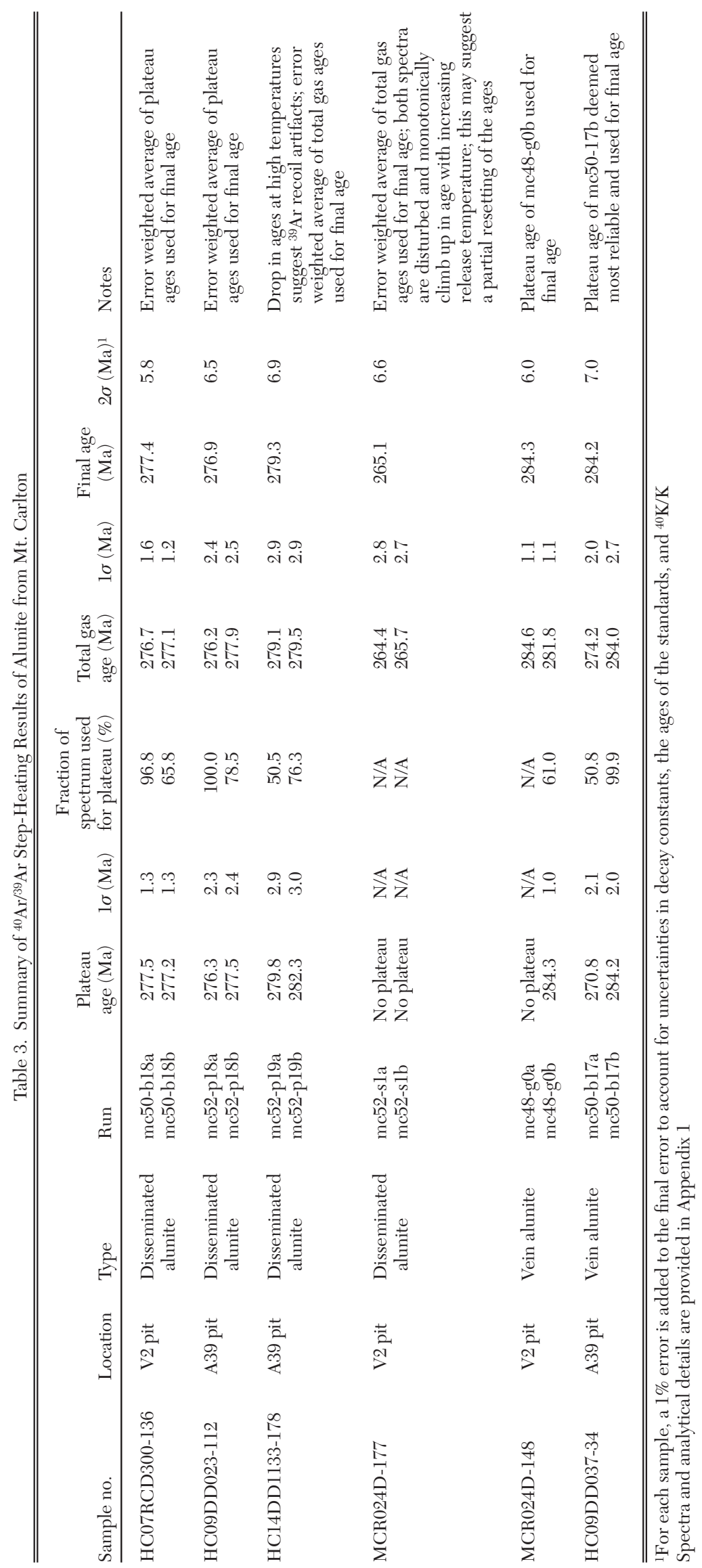


when present, this alteration feature could be a good exploration indicator for close proximity to the paleofluid conduits and potential epithermal mineralization.

The $\mathrm{Na}$ content in magmatic-hydrothermal alunite may locally be dependent on variability in the $\mathrm{Na}$ content of the host rocks that are being altered (Deyell and Dipple, 2005). However, in most cases where the host rocks are compositionally similar, an increasing $\mathrm{Na}$ content in alunite can be linked to higher temperatures of deposition (Stoffregen and Cygan, 1990; Deyell and Dipple, 2005; Chang et al., 2011). In the lithocap environment, the presence of near-end-member natroalunite as well as huangite $\left(\mathrm{Ca}_{0.5} \mathrm{Al}_{3}\left[\mathrm{SO}_{4}\right]_{2}[\mathrm{OH}]_{6}\right)$ generally suggests high formation temperatures and proximity to the causative intrusion (Chang et al., 2011). The mostly K dominated compositions of Mt. Carlton alunite (Figs. 15E, 16), therefore, could indicate relatively low formation temperatures, implying that the Mt. Carlton lithocap formed distal to the causative intrusion. The spatial zonation in the $\mathrm{Na}$ content of alunite at Mt. Carlton (Fig. 16) suggests that the formation temperatures were higher in the V2 pit compared to the $\mathrm{A} 39$ pit.

\section{Interpreted environment of mineralization at Mt. Carlton}

The sedimentary ore textures observed in the A39 pit at Mt. Carlton (Fig. 13) are similar to those described from other high-sulfidation deposits, including Rodalquilar, Spain (Arribas et al., 1995a), Akaiwa, Japan (Arribas, 1995b), Martabe, Indonesia (Sutopo, 2013), Golden Wonder mine, Colorado (Kalliokoski and Rehn, 1987), Los Porfirios, Chile (A. Arribas, unpub. data, 2005), and Mulatos, Mexico (J. Hedenquist, pers. commun., 2017). At the Rodalquilar deposit, acidic hydrothermal fluids have dissolved the volcanic host rocks along steeply dipping fractures, which produced isolated cavities at depth (Arribas et al., 1995a). Such dissolution cavities, which locally can be more than $1 \mathrm{~m}$ wide, have subsequently been infilled with subhorizontally layered sediments made up of chalcedony, quartz, and Au-rich sulfides. The siliceous sediments at Rodalquilar locally exhibit intricate cross-laminations and slumping textures, and they are commonly thicker on the bottom than on the sides of the cavities, due to gravitational infilling (Arribas et al., 1995a). These morphological features suggest that the sediments were precipitated from a hydrothermal fluid as amorphous silica, which later recrystallized to chalcedony and quartz (Fournier, 1985; Arribas et al., 1995a). Furthermore, a basal layer of igneous quartz phenocrysts was observed in some of the larger cavities. Such quartz layers were interpreted to have formed after the complete dissolution of all rock components except quartz, which accumulated at the bottom of the cavity (Arribas et al., 1995a). At the Los Porfirios deposit, dissolution cavities are partially infilled with sedimentary layers of quartz intercalated with barite, and silica speleothems (flowstones) were deposited locally along the cavity walls (A. Arribas, unpub. data, 2005). Sedimentary infill in similar cavities at the Akaiwa deposit comprises laminated quartz as well as discrete layers of barite and other hydrothermal minerals (e.g., alunite, kaolinite, dickite, and sulfides; Arribas, 1995b). These cavities were interpreted as pipes that composed the roots of overlying crater lakes (Arribas, 1995b).
At Mt. Carlton, mineralized sediments occur as infill within open spaces such as cavities along fractures (Fig. 13A-C), but they have also been observed in the volcanolacustrine sequence (unit 4A; Fig. 13D) extending at the scale of the A39 pit. The finely laminated siliceous sediments observed at Mt. Carlton (Fig. 13A, C) are similar to the chemical sediments that accumulate in acidic lacustrine environments, such as crater lakes (Sillitoe, 2015). The spherulitic pyrite at Mt. Carlton (Fig. 13D) bears a strong resemblance to that documented in ore deposits forming in and around hydrothermal vents (e.g., Larter et al., 1981; Tufar, 1991; Vearncombe et al., 1995; Scotney et al., 2005; Xu and Scott, 2005; Badrzadeh et al., 2011). In the seafloor environment, spherulitic pyrite is believed to form by rapid crystallization with undercooling, as hot metalliferous vent fluids discharge into cold ambient seawater (Xu and Scott, 2005). The synsedimentary normal faults and breccia-related soft-sediment deformation textures observed within some infilled fracture cavities at Mt. Carlton (Fig. 13A, B) indicate that sedimentation took place during active rifting. Furthermore, the detrital nature of sediments, the graded bedding, and the draping over preexisting topography observed within some fracture fills (Fig. 13B) are inconsistent with sediments having been deposited into isolated cavities at depth (e.g., Rodalquilar; Arribas et al., 1995a). We infer that fractures such as the one shown in Figure 13B must have been open to the paleosurface, which would have allowed detrital sediments to slump into the fractures and deposit from suspension.

Based on the rift-related tectonostratigraphic setting identified at Mt. Carlton, combined with the ore textures observed, the environment of mineralization is interpreted to have included structurally controlled feeder zones of veins and hydrothermal breccias that developed within the deeper rhyodacite porphyry (represented by rocks of the V2 pit). The feeder zones focused ore fluids into an overlying volcanolacustrine sedimentary sequence, which most likely was deposited in lakes developed within localized rift basins (represented by rocks of the A39 pit). In this interpretation, the fluids locally breached the paleosurface and discharged into the lakes at the same time as the volcanolacustrine sediments were deposited, producing the observed stratabound mineralization, laminated siliceous sediments, spherulitic pyrite, and associated synsedimentary ore textures. Sediments were sporadically slumped into the fractures that composed the structural roots of the rift basins, where interaction with the ascending ore fluids produced similar textures within open spaces at depth.

\section{Tectonic setting at Mt. Carlton and implications for exploration}

Due to the shallow environment of formation and the high erosion rates in most volcanic arcs, the preservation potential of high-sulfidation deposits is generally poor, such that most known deposits are of Tertiary age or younger (Arribas, 1995a). The Paleozoic age and the exceptional preservation (including what is interpreted as mineralized paleosurface and near-surface features) of Mt. Carlton is, therefore, remarkable.

Throughout the Paleozoic and Mesozoic, the eastern margin of Australia was extensional for long durations of time, caused by rollback of the subducting plate and repeated eastward migration of the subduction system. As a result, the 
basement rocks in the overriding plate were extended, and back-arc basins (e.g., the Drummond Basin and the Bowen Basin) developed on top of the extending basement (e.g., Donchak et al., 2013). The structural observations at Mt. Carlton indicate that the mineralization formed along the axis of the northern Bowen Basin during the onset of the Early Permian back-arc rifting stage, consistent with the ${ }^{40} \mathrm{Ar} /{ }^{39} \mathrm{Ar}$ dating results. Prolonged extension in the Bowen Basin provided rapid burial of the Mt. Carlton deposit beneath postmineralization volcanosedimentary cover. Preservation of epithermal paleosurface features tends to be geographically confined to either extensional (commonly back-arc) regions characterized by semiarid climates and relatively low erosion rates (e.g., the Great Basin, Mexican Altiplano, Deseado Massif, and Drummond Basin) or the highly arid central Andes (Sillitoe, 2015). The preservation of the Mt. Carlton deposit is thus strongly linked to the extensional setting in which it formed.

Postmineralization extension, most notably during $\mathrm{D}_{2}$ and $\mathrm{D}_{4}$, has caused significant tectonic modification of the Mt. Carlton deposit, including rotation and segmentation of the stratigraphy and the ore zones. This deformation also has important implications for exploration for linked porphyry mineralization in the area. Assuming a similar scenario as documented at the coupled Far Southeast porphyry and Lepanto high-sulfidation deposits at Mankayan, Philippines (Arribas et al., 1995b; Hedenquist et al., 1998; Chang et al., 2011), the mineralized feeders at Mt. Carlton should theoretically extend to the causative intrusion. Based on the present-day shape of the ore zones, with mineralization occurring in predominantly NE to NNE trending fractures, and the vectors defined by the metal zonation (distal Ag-Pb-Zn to proximal $\mathrm{Au}-\mathrm{Cu}$, from southwest to northeast; Fig. 3), alunite composition (increasing $\mathrm{Na}$ content to the northeast; Fig. 16), and ore textures (shallow stratabound ore in the southwest, mineralized feeders in the northeast) within the Mt. Carlton deposit, the simplest assumption would be that more proximal mineralization should occur to the northeast of the current V2 pit. However, drilling and induced polarization (IP) geophysical surveys conducted at Mt. Carlton have so far been unsuccessful in detecting any high-grade extensions to the immediate northeast of the V2 pit (M. Obiri-Yeboah, pers. commun., 2017). Most likely, the low-angle normal faults that developed during $\mathrm{D}_{2}$ have cut the feeders at deeper levels (e.g., at the contacts between units 2 and 3 , and between unit 2 and the granite basement). This scenario would be similar to the postmineralization detachment faulting described at the Paradise Peak high-sulfidation deposit in Nevada (Sillitoe and Lorson, 1994). The deeper parts of the feeder system as well as potential linked porphyry mineralization should, therefore, be displaced relative to the currently mined Mt. Carlton deposit. Based on the kinematics of $\mathrm{D}_{2}$ faults observed in the open pits, this displacement is expected to be to the west of Mt. Carlton. Since mineralization occurs in the deeper parts of the stratigraphy, where $\mathrm{D}_{2}$ faults are poorly developed, the amount of such displacement is most likely relatively small (e.g., on the order of tens to hundreds of meters). NNW-trending $\mathrm{D}_{4}$ normal faults, similar to the one that passes between the two open pits, also occur to the northeast of the V2 pit and to the southwest of the A39 pit, respectively. The potentially major displacement across such structures and associated block rotation add an extra layer of complexity to the development of exploration vectors in the Mt. Carlton district.

\section{Concluding remarks}

The study of the Mt. Carlton deposit highlights that shallowlevel high-sulfidation epithermal mineralization can be preserved in Paleozoic settings under appropriate geodynamic conditions. We suggest that extensional segments of volcanic arcs, such as back-arc rifts, are particularly prospective for this type of mineralization. The study also highlights the need to understand the postmineralization tectonic modification of the porphyry-epithermal system in extensional settings and concerns exploration in the northern Bowen Basin and similar geologic terranes elsewhere.

\section{Acknowledgments}

This study was funded by Evolution Mining and the Geological Survey of Queensland (GSQ). It was performed as part of Fredrik Sahlström's Ph.D. thesis, and he would like to express his gratitude for a postgraduate research scholarship from James Cook University (JCU) and for a student research grant from the Hugh E. McKinstry Fund awarded by the Society of Economic Geologists (SEG). We thank Evolution Mining for providing access to the Mt. Carlton mine and extensive exploration data sets, and the on-site staff for their assistance and fruitful discussions during field work. Franz Weis is gratefully acknowledged for performing the XRD analyses. This manuscript was significantly improved by thoughtful reviews from David Cooke, José Piquer, and one anonymous reviewer.

\section{REFERENCES}

Allen, C., Williams, I., Stephens, C., and Fielding, C., 1998, Granite genesis and basin formation in an extensional setting: The magmatic history of the northernmost New England orogen: Australian Journal of Earth Sciences, v. 45 , p. $875-888$.

Allen, J.P., and Fielding, C.R., 2007, Sequence architecture within a lowaccommodation setting: An example from the Permian of the Galilee and Bowen basins, Queensland, Australia: AAPG Bulletin, v. 91, p. 1503-1539.

Aoki, M., Comsti, E.C., Lazo, F.B., and Matsuhisa, Y., 1993, Advanced argillic alteration and geochemistry of alunite in an evolving hydrothermal system at Baguio, northern Luzon, Philippines: Resource Geology, v. 43, p. 155-164.

Arribas, A., 1995a, Characteristics of high-sulfidation epithermal deposits, and their relation to magmatic fluid: Mineralogical Association of Canada Short Course Series, v. 23, p. 419-454.

1995b, The tops of high-sulfidation epithermal gold deposits: Roots of acidic crater lakes [abs.]: Society for Geology Applied to Mineral Deposits, Third Biennial SGA Meeting, Prague, Czech Republic, 1995, Abstracts, p. 8-9.

Arribas, A., Cunningham, C.G., Rytuba, J.J., Rye, R.O., Kelly, W.C., Podwysocki, M.H., McKee, E.H., and Tosdal, R.M., 1995a, Geology, geochronology, fluid inclusions, and isotope geochemistry of the Rodalquilar gold alunite deposit, Spain: Economic Geology, v. 90, p. 795-822.

Arribas, A., Hedenquist, J.W., Itaya, T., Okada, T., Concepción, R.A., and Garcia, J.S., 1995b, Contemporaneous formation of adjacent porphyry and epithermal $\mathrm{Cu}-\mathrm{Au}$ deposits over $300 \mathrm{ka}$ in northern Luzon, Philippines: Geology, v. 23, p. 337-340.

Arribas, A., Arribas, I., Draper, G., Hall, C., Kesler, S.E., McEwan, C., and Muntean, J.L., 2011, ${ }^{40} \mathrm{Ar} /{ }^{39} \mathrm{Ar}$ dating of alunite from the Pueblo Viejo goldsilver district, Dominican Republic: Economic Geology, v. 106, p. 1059-1070.

Badrzadeh, Z., Barrett, T.J., Peter, J.M., Gimeno, D., Sabzehei, M., and Aghazadeh, M., 2011, Geology, mineralogy, and sulfur isotope geochemistry of the Sargaz Cu-Zn volcanogenic massive sulfide deposit, SanandajSirjan zone, Iran: Mineralium Deposita, v. 46, p. 905-923.

Bain, J.H., and Draper, J., 1997, North Queensland geology: Bulletin of the Australian Geological Survey Organisation, v. 240, p. 1-600. 
Blevin, P.L., Chappell, B.W., and Allen, C.M., 1996, Intrusive metallogenic provinces in eastern Australia based on granite source and composition: Geological Society of America Special Papers, v. 315, p. 281-290.

Champion, D.C., and Bultitude, R.J., 2013, Kennedy Igneous Association, in Jell, P.A., ed., Geology of Queensland: Brisbane, Geological Survey of Queensland, p. 473-514.

Champion, D.C., and Mackenzie, D.E., 1994, Igneous rocks of north Queensland: Australian Geological Survey Organisation, Metallogenic Atlas Series 2, $46 \mathrm{p}$.

Chang, Z., and Yang, Z., 2012, Evaluation of inter-instrument variations among short wavelength infrared (SWIR) devices: Economic Geology, v. 107 , p. $1479-1488$

Chang, Z., Hedenquist, J.W., White, N.C., Cooke, D.R., Roach, M., Deyell, C.L., Garcia, Jr., J., Gemmell, J.B., McKnight, S., and Cuison, A.L., 2011, Exploration tools for linked porphyry and epithermal deposits: Example from the Mankayan intrusion-centered $\mathrm{Cu}-\mathrm{Au}$ district, Luzon, Philippines: Economic Geology, v. 106, p. 1365-1398.

Cooke, D.R., and Simmons, S.F., 2000, Characteristics and genesis of epithermal gold deposits: Reviews in Economic Geology, v. 13, p. 221-244.

Coughlin, T., 1995, The structural setting and mineralisation characteristics of the Mount Carlton Group of epithermal precious metal prospects located in the north Bowen Basin, north east Queensland, Australia: Unpublished M.Sc. thesis, Townsville, Australia, James Cook University, 127 p.

Cunningham, C.G., Rye, R.O., Steven, T.A., and Mehnert, H.H., 1984, Origins and exploration significance of replacement and vein-type alunite deposits in the Marysvale volcanic field, west central Utah: Economic Geology, v. 79 , p. $50-71$.

Deyell, C., and Dipple, G., 2005, Equilibrium mineral-fluid calculations and their application to the solid solution between alunite and natroalunite in the El Indio-Pascua belt of Chile and Argentina: Chemical Geology, v. 215, p. 219-234

Deyell, C., Leonardson, R., Rye, R.O., Thompson, J.F.H., Bissig, T., and Cooke, D.R., 2005a, Alunite in the Pascua-Lama high-sulfidation deposit: Constraints on alteration and ore deposition using stable isotope geochemistry: Economic Geology, v. 100, p. 131-148.

Deyell, C., Rye, R., Landis, G., and Bissig, T., 2005b, Alunite and the role of magmatic fluids in the Tambo high-sulfidation deposit, El Indio-Pascua belt, Chile: Chemical Geology, v. 215, p. 185-218

Donchak, P., Purdy, D.J., Withnall, I., Blake, P., and Jell, P.A., 2013, New England orogen, in Jell, P.A., ed., Geology of Queensland: Brisbane, Geological Survey of Queensland, p. 305-472.

Einaudi, M.T., Hedenquist, J.W., and Inan, E.E., 2003, Sulfidation state of fluids in active and extinct hydrothermal systems: Transitions from porphyry to epithermal environments: Society of Economic Geologists, Special Publication 10, p. 285-314.

Esterle, J.S., Sliwa, R., Smith, G.L.B., Yago, J.V.R., Williams, R., Li, S., and Dimitrakopoulos, R., 2002, Bowen basin supermodel 2000: Kenmore, CSIRO Exploration and Mining, $180 \mathrm{p}$.

Fergusson, C.L., 1991, Thin-skinned thrusting in the northern New England orogen, central Queensland, Australia: Tectonics, v. 10, p. 797-806.

Fielding, C., Falkner, A., Kassan, J., and Draper, J., 1990, Permian and Triassic depositional systems in the Bowen Basin [abs.]: Geological Society of Australia, Bowen Basin Symposium, Brisbane, 1990, Proceedings, p. 21-25.

Fournier, R.O., 1985, The behaviour of silica in hydrothermal solutions: Reviews in Economic Geology, v. 2, p. 45-59.

Frey, H.M., Lange, R.A., Hall, C.M., Delgado-Granados, H., and Carmichael, I.S., 2007, A Pliocene ignimbrite flare-up along the Tepic-Zacoalco rift: Evidence for the initial stages of rifting between the Jalisco block (Mexico) and North America: Geological Society of America Bulletin, v. 119, p. 49-64.

Gonzalez, A., 1959, Geology and genesis of the Lepanto copper deposit, Mankayan, Mountain province, Philippines: Unpublished Ph.D. thesis, Stanford, Stanford University, $102 \mathrm{p}$.

Hedenquist, J.W., 1987, Mineralization associated with volcanic-related hydrothermal systems in the Circum-Pacific Basin [ext. abs.]: CircumPacific Council for Energy and Mineral Resources, Circum-Pacific Energy and Mineral Resources Conference, 4th, Tulsa, United States, 1986, Extended Abstracts, p. 513-524.

Hedenquist, J.W., and Lowenstern, J.B., 1994, The role of magmas in the formation of hydrothermal ore deposits: Nature, v. 370, p. 519-527.

Hedenquist, J.W., and Taran, Y.A., 2013, Modeling the formation of advanced argillic lithocaps: Volcanic vapor condensation above porphyry intrusions: Economic Geology, v. 108, p. 1523-1540.
Hedenquist, J.W., Simmons, S.F., Giggenbach, W.F., and Eldridge, C.S. 1993, White Island, New Zealand, volcanic-hydrothermal system represents the geochemical environment of high-sulfidation $\mathrm{Cu}$ and $\mathrm{Au}$ ore deposition: Geology, v. 21, p. 731-734.

Hedenquist, J.W., Arribas, A., and Reynolds, T.J., 1998, Evolution of an intrusion-centered hydrothermal system: Far Southeast-Lepanto porphyry and epithermal $\mathrm{Cu}-\mathrm{Au}$ deposits, Philippines: Economic Geology, v. 93 p. 373-404.

Hedenquist, J.W., Arribas, A., and Gonzalez-Urien, E., 2000, Exploration for epithermal gold deposits: Reviews in Economic Geology, v. 13, p. 245-277.

Henderson, R., 1980, Structural outline and summary of geological history for northeastern Australia, in Henderson, R.A., and Stephenson, P.J., eds., The geology and geophysics of northeastern Australia: Brisbane, Geological Society of Australia-Queensland Division, p. 1-26.

Holcombe, R., Stephens, C., Fielding, C., Gust, D., Little, T., Sliwa, R., Kassan, J., McPhie, J., and Ewart, A., 1997, Tectonic evolution of the northern New England fold belt: The Permian-Triassic Hunter-Bowen event: Geological Society of Australia Special Publication, v. 19, p. 52-65.

Hutton, L., Withnall, I., Rienks, I., Bultitude, R.J., Hayward, M., von Gneilinski, F., Fordham, B., and Simpson, G., 1999, A preliminary Carboniferous to Permian magmatic framework for the Auburn and Connors Arches, central Queensland: University of New England, New England Orogen Conference, Armidale, Australia, 1999, Proceedings, p. 223-232.

Itaya, T., Arribas, A., and Okada, T., 1996, Argon release systematics of hypogene and supergene alunite based on progressive heating experiments from 100 to $1000^{\circ} \mathrm{C}$ : Geochimica et Cosmochimica Acta, v. 60, p. 4525-4535.

Jambor, J.L., 1999, Nomenclature of the alunite supergroup: Canadian Mineralogist, v. 37, p. 1323-1341

Johnson, N.E., Craig, J.R., and Rimstidt, J.D., 1986, Compositional trends in tetrahedrite: Canadian Mineralogist, v. 24, p. 385-397.

Kalliokoski, J., and Rehn, P., 1987, Geology of the veins and vein sediments, of the Golden Wonder Mine, Lake City, Colorado; an epithermal hot springs gold-alunite deposit: USGS Open-File Report 87-344, 47 p.

Kesler, S.E., and Wilkinson, B.H., 2006, The role of exhumation in the temporal distribution of ore deposits: Economic Geology, v. 101, p. 919-922.

Korsch, R., and Totterdell, J., 2009, Subsidence history and basin phases of the Bowen, Gunnedah and Surat basins, eastern Australia: Australian Journal of Earth Sciences, v. 56, p. 335-353.

Korsch, R., Totterdell, J., Cathro, D., and Nicoll, M., 2009, Early Permian east Australian rift system: Australian Journal of Earth Sciences, v. 56, p. 381-400

Kretz, R., 1983, Symbols for rock-forming minerals: American Mineralogist, v. 68 , p. $277-279$.

Larter, R., Boyce, A., and Russell, M., 1981, Hydrothermal pyrite chimneys from the Ballynoe baryte deposit, Silvermines, County Tipperary, Ireland: Mineralium Deposita, v. 16, p. 309-317.

Malone, E.J., Olgers, F., and Kirkegaard, A., 1969, The geology of the Duaringa and Saint-Lawrence 1:250,000 sheet areas, Queensland: Canberra, Bureau of Mineral Resources, Geology and Geophysics, Report 121, 133 p. Murray, C.G., 1990, Tectonic evolution and metallogenesis of the Bowen Basin [abs.]: Geological Society of Australia, Bowen Basin Symposium, Brisbane, 1990, Abstracts, p. 201-212.

Paine, A., Clarke, D.E., and Gregory, C.M., 1974, Geology of the northern half of the Bowen 1:250,000 sheet area, Queensland (with additions to the geology of the southern half): Canberra, Bureau of Mineral Resources, Geology and Geophysics, Report 145, $86 \mathrm{p}$.

Rooney, T.O., Mohr, P., Dosso, L., and Hall, C., 2013, Geochemical evidence of mantle reservoir evolution during progressive rifting along the western Afar margin: Geochimica et Cosmochimica Acta, v. 102, p. 65-88.

Rye, R.O., 2005, A review of the stable-isotope geochemistry of sulfate minerals in selected igneous environments and related hydrothermal systems: Chemical Geology, v. 215, p. 5-36.

Rye, R.O., Bethke, P.M., and Wasserman, M.D., 1992, The stable isotope geochemistry of acid sulfate alteration: Economic Geology, v. 87, p. 225-262

Sahlström, F., Corral, I., Chang, Z., Arribas, A., Dirks, P., Stokes, M., Pocock, M., Hewitt, D., and Obiri-Yeboah, M., 2016, Hydrothermal alteration and mineralisation at the Mt Carlton high-sulphidation $\mathrm{Au}-\mathrm{Ag}-\mathrm{Cu}$ epithermal deposit (NE Queensland, Australia) [abs.]: Geochemical Society, 2016 Goldschmidt Conference, Yokohama, Japan, June 26-July 1, 2016 , Abstracts, p. 2688

Sahlström, F., Arribas, A., Dirks, P., Corral, I., and Chang, Z., 2017a, Mineralogical distribution of germanium, gallium and indium at the Mt Carlton high-sulfidation epithermal deposit, NE Australia, and comparison with similar deposits worldwide: Minerals, v. 7, 28 p. 
Sahlström, F., Blake, K., Corral, I., and Chang, Z., 2017b, Hyperspectral cathodoluminescence study of indium-bearing sphalerite from the Mt Carlton high-sulphidation epithermal deposit, Queensland, Australia: European Journal of Mineralogy, v. 29, p. 985-993.

Scotney, P.M., Roberts, S., Herrington, R.J., Boyce, A.J., and Burgess, R., 2005, The development of volcanic hosted massive sulfide and baritegold orebodies on Wetar Island, Indonesia: Mineralium Deposita, v. 40, p. 76-99.

Sillitoe, R.H., 1993, Epithermal models: Genetic types, geometrical controls and shallow features: Geological Association of Canada Special Paper, v. 40, p. 403-417.

1995, Exploration of porphyry copper lithocaps: Australasian Institute of Mining and Metallurgy, Publication Series, v. 9, p. 527-532.

1999, Styles of high-sulphidation gold, silver and copper mineralisation in porphyry and epithermal environments [abs.]: Australasian Institute of Mining and Metallurgy, PACRIM Congress, Bali, Indonesia, 1999, Abstracts, p. 29-44

2010, Porphyry copper systems: Economic Geology, v. 105, p. 3-41.

2015, Epithermal paleosurfaces: Mineralium Deposita, v. 50, p. 767-793.

Sillitoe, R.H., and Hedenquist, J.W., 2003, Linkages between volcanotectonic settings, ore-fluid compositions, and epithermal precious metal deposits: Society of Economic Geologists, Special Publication 10, p. 315-343.

Sillitoe, R.H., and Lorson, R.C., 1994, Epithermal gold-silver-mercury deposits at Paradise Peak, Nevada: Ore controls, porphyry gold association, detachment faulting, and supergene oxidation: Economic Geology, v. 89, p. $1228-1248$

Singer, D.A., 1995, World class base and precious metal deposits—a quantitative analysis: Economic Geology, v. 90, p. 88-104.

Springer, G., 1969, Compositional variations in enargite and luzonite: Mineralium Deposita, v. 4, p. 72-74.

Steven, T.A., and Ratté, J.C., 1960, Geology and ore deposits of the Summitville district, San Juan Mountains, Colorado: U.S. Geological Survey, Professional Paper 343, p. 70.
Stoffregen, R.E., 1987, Genesis of acid-sulfate alteration and Au-CuAg mineralization at Summitville, Colorado: Economic Geology, v. 82, p. $1575-1591$.

Stoffregen, R.E., and Alpers, C.N., 1987, Woodhouseite and svanbergite in hydrothermal ore deposits; products of apatite destruction during advanced argillic alteration: Canadian Mineralogist, v. 25, p. 201-211.

Stoffregen, R.E, and Cygan, G.L., 1990, An experimental study of Na-K exchange between alunite and aqueous sulfate solutions: American Mineralogist, v. 75 , p. 209-220.

Sutopo, B., 2013, The Martabe Au-Ag high-sulfidation epithermal deposits, Sumatra, Indonesia: Implications for ore genesis and exploration: Unpublished Ph.D. thesis, Hobart, University of Tasmania, $352 \mathrm{p}$.

Tosdal, R., and Richards, J., 2001, Magmatic and structural controls on the development of porphyry $\mathrm{Cu} \pm \mathrm{Mo} \pm \mathrm{Au}$ deposits: Reviews in Economic Geology, v. 14, p. 157-181.

Trudu, A.G., and Knittel, U., 1998, Crystallography, mineral chemistry and chemical nomenclature of goldfieldite, the tellurian member of the tetrahedrite solid-solution series: Canadian Mineralogist, v. 36, p. 1115-1138.

Tufar, W., 1991, Paragenesis of complex massive sulfide ores from the Tyrrhenian Sea: Mitteilungen der Österreichischen Geologischen Gesellschaft, v. 84 , p. $265-300$.

Vearncombe, S., Barley, M., Groves, D., McNaughton, N., Mikucki, E., and Vearncombe, J., 1995, 3.26 Ga black smoker-type mineralization in the Strelley belt, Pilbara craton, Western Australia: Journal of the Geological Society, v. 152 , p. 587-590.

Xu, Q., and Scott, S.D., 2005, Spherulitic pyrite in seafloor hydrothermal deposits: Products of rapid crystallization from mixing fluids, in Mao, J., and Bierlein, F.P., eds., Mineral deposit research: Meeting the global challenge, v. 1: Berlin, Springer, p. 711-713. 
APPENDIX 1

${ }^{40} \mathrm{Ar} /{ }^{39} \mathrm{Ar}$ Data for Alunite from Mt. Carlton

\begin{tabular}{|c|c|c|c|c|c|c|c|c|c|c|}
\hline $\begin{array}{l}\text { Laser } \\
\text { power } \\
(\mathrm{mW})\end{array}$ & ${ }^{36} \mathrm{Ar}$ & $\pm 1 \sigma$ & ${ }^{37} \mathrm{Ar}$ & $\pm 1 \sigma$ & ${ }^{38} \mathrm{Ar}$ & $\pm 1 \sigma$ & ${ }^{39} \mathrm{Ar}$ & $\pm 1 \sigma$ & ${ }^{40} \mathrm{Ar}$ & $\pm 1 \sigma$ \\
\hline \multicolumn{11}{|c|}{ HC07RCD300-136 (run mc50-b18a) } \\
\hline 100 & $9.64 \mathrm{E}-03$ & $2.31 \mathrm{E}-03$ & $9.25 \mathrm{E}-03$ & $1.43 \mathrm{E}-02$ & $2.57 \mathrm{E}-03$ & $1.24 \mathrm{E}-03$ & $1.30 \mathrm{E}-02$ & $2.35 \mathrm{E}-03$ & $3.13 \mathrm{E}+00$ & $2.06 \mathrm{E}-02$ \\
\hline 200 & $4.49 \mathrm{E}-03$ & $2.01 \mathrm{E}-03$ & $3.17 \mathrm{E}-02$ & $1.27 \mathrm{E}-02$ & 7.73E-03 & $1.74 \mathrm{E}-03$ & $1.05 \mathrm{E}-01$ & $2.73 \mathrm{E}-03$ & $8.30 \mathrm{E}+00$ & $2.31 \mathrm{E}-02$ \\
\hline 300 & $5.03 \mathrm{E}-03$ & $2.07 \mathrm{E}-03$ & $1.90 \mathrm{E}-02$ & $1.32 \mathrm{E}-02$ & $2.94 \mathrm{E}-03$ & $1.86 \mathrm{E}-03$ & $4.81 \mathrm{E}-01$ & $6.48 \mathrm{E}-03$ & $4.56 \mathrm{E}+01$ & $8.52 \mathrm{E}-02$ \\
\hline 400 & $7.37 \mathrm{E}-03$ & $2.47 \mathrm{E}-03$ & $2.86 \mathrm{E}-02$ & $1.38 \mathrm{E}-02$ & $7.45 \mathrm{E}-03$ & $2.94 \mathrm{E}-03$ & $4.50 \mathrm{E}-01$ & $3.28 \mathrm{E}-03$ & $4.40 \mathrm{E}+01$ & $6.49 \mathrm{E}-02$ \\
\hline 600 & $2.09 \mathrm{E}-02$ & $2.05 \mathrm{E}-03$ & $2.91 \mathrm{E}-02$ & $1.41 \mathrm{E}-02$ & $8.29 \mathrm{E}-03$ & $1.72 \mathrm{E}-03$ & $8.76 \mathrm{E}-01$ & $3.68 \mathrm{E}-03$ & $8.80 \mathrm{E}+01$ & $1.50 \mathrm{E}-01$ \\
\hline 800 & $2.43 \mathrm{E}-02$ & $1.22 \mathrm{E}-03$ & $1.86 \mathrm{E}-02$ & $4.62 \mathrm{E}-03$ & $8.94 \mathrm{E}-03$ & $1.67 \mathrm{E}-03$ & $1.55 \mathrm{E}+00$ & $6.80 \mathrm{E}-03$ & $1.53 \mathrm{E}+02$ & $2.37 \mathrm{E}-01$ \\
\hline 1000 & $2.54 \mathrm{E}-02$ & $1.81 \mathrm{E}-03$ & $1.69 \mathrm{E}-02$ & $6.15 \mathrm{E}-03$ & $9.61 \mathrm{E}-03$ & $1.93 \mathrm{E}-03$ & $1.25 \mathrm{E}+00$ & $5.51 \mathrm{E}-03$ & $1.25 \mathrm{E}+02$ & $1.94 \mathrm{E}-01$ \\
\hline 1200 & $1.76 \mathrm{E}-02$ & $1.57 \mathrm{E}-03$ & $2.84 \mathrm{E}-03$ & $5.73 \mathrm{E}-03$ & 7.38E-03 & $1.46 \mathrm{E}-03$ & $1.60 \mathrm{E}+00$ & $9.40 \mathrm{E}-03$ & $1.55 \mathrm{E}+02$ & $2.91 \mathrm{E}-01$ \\
\hline 1400 & $2.87 \mathrm{E}-02$ & $1.77 \mathrm{E}-03$ & $9.56 \mathrm{E}-03$ & $5.21 \mathrm{E}-03$ & $1.70 \mathrm{E}-02$ & $1.90 \mathrm{E}-03$ & $1.91 \mathrm{E}+00$ & $5.60 \mathrm{E}-03$ & $1.88 \mathrm{E}+02$ & $2.84 \mathrm{E}-01$ \\
\hline 1600 & $2.02 \mathrm{E}-02$ & $1.38 \mathrm{E}-03$ & $1.32 \mathrm{E}-03$ & $4.72 \mathrm{E}-03$ & $1.48 \mathrm{E}-02$ & $1.73 \mathrm{E}-03$ & $1.49 \mathrm{E}+00$ & $6.13 \mathrm{E}-03$ & $1.46 \mathrm{E}+02$ & $2.56 \mathrm{E}-01$ \\
\hline 1800 & $1.44 \mathrm{E}-02$ & $2.06 \mathrm{E}-03$ & 3.73E-02 & $9.76 \mathrm{E}-03$ & $1.65 \mathrm{E}-02$ & $1.93 \mathrm{E}-03$ & $1.54 \mathrm{E}+00$ & $7.29 \mathrm{E}-03$ & $1.52 \mathrm{E}+02$ & $2.78 \mathrm{E}-01$ \\
\hline 2000 & $6.93 \mathrm{E}-03$ & $1.32 \mathrm{E}-03$ & $3.26 \mathrm{E}-03$ & $7.95 \mathrm{E}-03$ & $1.28 \mathrm{E}-02$ & $2.80 \mathrm{E}-03$ & $1.32 \mathrm{E}+00$ & $5.67 \mathrm{E}-03$ & $1.27 \mathrm{E}+02$ & $2.13 \mathrm{E}-01$ \\
\hline 2400 & $1.49 \mathrm{E}-02$ & $1.50 \mathrm{E}-03$ & $8.94 \mathrm{E}-03$ & $9.09 \mathrm{E}-03$ & $1.48 \mathrm{E}-02$ & $2.35 \mathrm{E}-03$ & $1.72 \mathrm{E}+00$ & $7.25 \mathrm{E}-03$ & $1.67 \mathrm{E}+02$ & $1.90 \mathrm{E}-01$ \\
\hline 2800 & $2.33 \mathrm{E}-02$ & $1.75 \mathrm{E}-03$ & $1.28 \mathrm{E}-02$ & $9.15 \mathrm{E}-03$ & $1.44 \mathrm{E}-02$ & $2.83 \mathrm{E}-03$ & $1.77 \mathrm{E}+00$ & $6.44 \mathrm{E}-03$ & $1.72 \mathrm{E}+02$ & $2.97 \mathrm{E}-01$ \\
\hline 3200 & $1.99 \mathrm{E}-02$ & $1.99 \mathrm{E}-03$ & $1.59 \mathrm{E}-02$ & $7.53 \mathrm{E}-03$ & $1.15 \mathrm{E}-02$ & $1.97 \mathrm{E}-03$ & $1.84 \mathrm{E}+00$ & $5.10 \mathrm{E}-03$ & $1.79 \mathrm{E}+02$ & $3.02 \mathrm{E}-01$ \\
\hline 4000 & $1.59 \mathrm{E}-02$ & $1.53 \mathrm{E}-03$ & $2.72 \mathrm{E}-02$ & $7.79 \mathrm{E}-03$ & $1.58 \mathrm{E}-02$ & $1.96 \mathrm{E}-03$ & $1.90 \mathrm{E}+00$ & $6.06 \mathrm{E}-03$ & $1.84 \mathrm{E}+02$ & 2.87E-01 \\
\hline$=$ & $1.76 \mathrm{E}-03$ & \pm & $8.12 \mathrm{E}-06$ & & & & & & & \\
\hline
\end{tabular}

Cumulative Age ${ }^{39} \mathrm{Ar} \quad(\mathrm{Ma}) \quad \pm 1 \sigma$ $\pm 1 \sigma$

HC07RCD300-136 (run mc50-b18b)

\begin{tabular}{|c|c|c|c|c|c|c|c|c|c|c|c|c|c|}
\hline 100 & $1.25 \mathrm{E}-02$ & $1.99 \mathrm{E}-03$ & $-2.60 \mathrm{E}-03$ & $8.62 \mathrm{E}-03$ & $7.95 \mathrm{E}-03$ & $1.45 \mathrm{E}-03$ & $3.75 \mathrm{E}-03$ & $2.07 \mathrm{E}-03$ & $4.19 \mathrm{E}+00$ & $1.24 \mathrm{E}-02$ & 0.00 & 374.29 & 445.93 \\
\hline 200 & $7.69 \mathrm{E}-03$ & $1.38 \mathrm{E}-03$ & $8.71 \mathrm{E}-03$ & $1.22 \mathrm{E}-02$ & $4.51 \mathrm{E}-03$ & $1.41 \mathrm{E}-03$ & $3.67 \mathrm{E}-03$ & $2.13 \mathrm{E}-03$ & $2.08 \mathrm{E}+00$ & $1.45 \mathrm{E}-02$ & 0.00 & -171.78 & 402.10 \\
\hline 300 & $3.44 \mathrm{E}-03$ & $1.40 \mathrm{E}-03$ & $-2.94 \mathrm{E}-03$ & 8.33E-03 & $3.33 \mathrm{E}-03$ & $1.48 \mathrm{E}-03$ & $6.90 \mathrm{E}-03$ & $2.20 \mathrm{E}-03$ & $1.16 \mathrm{E}+00$ & $1.12 \mathrm{E}-02$ & 0.00 & 64.08 & 185.67 \\
\hline 400 & $2.38 \mathrm{E}-02$ & $2.21 \mathrm{E}-03$ & $8.86 \mathrm{E}-03$ & $9.21 \mathrm{E}-03$ & 6.89E-03 & $2.20 \mathrm{E}-03$ & $2.80 \mathrm{E}-02$ & $2.51 \mathrm{E}-03$ & $9.16 \mathrm{E}+00$ & $2.47 \mathrm{E}-02$ & 0.00 & 227.86 & 68.17 \\
\hline 600 & $1.23 \mathrm{E}-02$ & $1.69 \mathrm{E}-03$ & $8.06 \mathrm{E}-03$ & $8.80 \mathrm{E}-03$ & $5.49 \mathrm{E}-03$ & $1.87 \mathrm{E}-03$ & $5.84 \mathrm{E}-01$ & $3.28 \mathrm{E}-03$ & $5.71 \mathrm{E}+01$ & $1.08 \mathrm{E}-01$ & 0.03 & 269.56 & 2.77 \\
\hline 800 & $1.99 \mathrm{E}-02$ & $1.79 \mathrm{E}-03$ & $1.29 \mathrm{E}-02$ & $8.81 \mathrm{E}-03$ & $9.02 \mathrm{E}-03$ & $2.71 \mathrm{E}-03$ & $1.11 \mathrm{E}+00$ & $9.18 \mathrm{E}-03$ & $1.10 \mathrm{E}+02$ & $9.06 \mathrm{E}-02$ & 0.09 & 275.07 & 2.48 \\
\hline 1000 & $1.73 \mathrm{E}-02$ & 1.83E-03 & $8.33 \mathrm{E}-03$ & $9.93 \mathrm{E}-03$ & $1.35 \mathrm{E}-02$ & $2.64 \mathrm{E}-03$ & $1.64 \mathrm{E}+00$ & $7.82 \mathrm{E}-03$ & $1.58 \mathrm{E}+02$ & $2.81 \mathrm{E}-01$ & 0.17 & 274.39 & 1.58 \\
\hline 1200 & $1.23 \mathrm{E}-02$ & $1.91 \mathrm{E}-03$ & $1.46 \mathrm{E}-02$ & 7.01E-03 & $1.30 \mathrm{E}-02$ & $2.62 \mathrm{E}-03$ & $1.67 \mathrm{E}+00$ & $6.42 \mathrm{E}-03$ & $1.60 \mathrm{E}+02$ & $3.29 \mathrm{E}-01$ & 0.25 & 275.78 & 1.45 \\
\hline 1400 & $1.73 \mathrm{E}-02$ & 2.16E-03 & $1.16 \mathrm{E}-02$ & $6.88 \mathrm{E}-03$ & $1.78 \mathrm{E}-02$ & $2.44 \mathrm{E}-03$ & $2.47 \mathrm{E}+00$ & $8.07 \mathrm{E}-03$ & $2.39 \mathrm{E}+02$ & $3.09 \mathrm{E}-01$ & 0.37 & 277.62 & 1.15 \\
\hline 1600 & $2.70 \mathrm{E}-02$ & $1.93 \mathrm{E}-03$ & $1.10 \mathrm{E}-02$ & 7.83E-03 & $1.72 \mathrm{E}-02$ & $3.23 \mathrm{E}-03$ & $1.98 \mathrm{E}+00$ & $6.91 \mathrm{E}-03$ & $1.94 \mathrm{E}+02$ & $3.43 \mathrm{E}-01$ & 0.47 & 275.38 & 1.28 \\
\hline 1800 & $1.21 \mathrm{E}-02$ & $2.03 \mathrm{E}-03$ & $2.57 \mathrm{E}-02$ & $7.46 \mathrm{E}-03$ & $1.12 \mathrm{E}-02$ & $1.54 \mathrm{E}-03$ & $1.86 \mathrm{E}+00$ & 7.03E-03 & $1.79 \mathrm{E}+02$ & $3.10 \mathrm{E}-01$ & 0.56 & 277.13 & 1.39 \\
\hline 2000 & $9.91 \mathrm{E}-03$ & $1.44 \mathrm{E}-03$ & $6.95 \mathrm{E}-03$ & $5.47 \mathrm{E}-03$ & $8.72 \mathrm{E}-03$ & $1.52 \mathrm{E}-03$ & $1.59 \mathrm{E}+00$ & $6.05 \mathrm{E}-03$ & $1.54 \mathrm{E}+02$ & $2.29 \mathrm{E}-01$ & 0.64 & 279.12 & 1.28 \\
\hline 2400 & $2.04 \mathrm{E}-02$ & $1.54 \mathrm{E}-03$ & $2.00 \mathrm{E}-02$ & $5.52 \mathrm{E}-03$ & $1.27 \mathrm{E}-02$ & $1.46 \mathrm{E}-03$ & $1.85 \mathrm{E}+00$ & $8.15 \mathrm{E}-03$ & $1.81 \mathrm{E}+02$ & $3.38 \mathrm{E}-01$ & 0.73 & 278.16 & 1.41 \\
\hline 2800 & $1.41 \mathrm{E}-02$ & $1.91 \mathrm{E}-03$ & 2.79E-02 & $7.20 \mathrm{E}-03$ & $1.10 \mathrm{E}-02$ & $1.44 \mathrm{E}-03$ & $1.93 \mathrm{E}+00$ & $6.55 \mathrm{E}-03$ & $1.86 \mathrm{E}+02$ & $2.53 \mathrm{E}-01$ & 0.82 & 276.92 & 1.24 \\
\hline 3200 & $1.66 \mathrm{E}-02$ & $2.12 \mathrm{E}-03$ & 4.67E-03 & $8.87 \mathrm{E}-03$ & $1.13 \mathrm{E}-02$ & $2.51 \mathrm{E}-03$ & $1.87 \mathrm{E}+00$ & $9.13 \mathrm{E}-03$ & $1.85 \mathrm{E}+02$ & $2.55 \mathrm{E}-01$ & 0.92 & 282.20 & 1.61 \\
\hline 4000 & $1.06 \mathrm{E}-02$ & $2.15 \mathrm{E}-03$ & $2.11 \mathrm{E}-02$ & $1.23 \mathrm{E}-02$ & $7.98 \mathrm{E}-03$ & $2.90 \mathrm{E}-03$ & $1.68 \mathrm{E}+00$ & $7.59 \mathrm{E}-03$ & $1.63 \mathrm{E}+02$ & $2.13 \mathrm{E}-01$ & 1.00 & 279.66 & 1.60 \\
\hline
\end{tabular}

$\mathrm{J}=\quad 1.76 \mathrm{E}-03 \quad \pm \quad 8.12 \mathrm{E}-06$

HC09DD023-112 (run mc52-p18a)

\begin{tabular}{|c|c|c|c|c|c|c|c|c|c|c|c|c|c|}
\hline & & & & & & & & & & & & & \\
\hline 100 & $1.24 \mathrm{E}-03$ & $1.79 \mathrm{E}-03$ & $3.40 \mathrm{E}-02$ & $1.22 \mathrm{E}-02$ & $1.65 \mathrm{E}-02$ & $3.53 \mathrm{E}-03$ & $5.93 \mathrm{E}-02$ & $1.75 \mathrm{E}-03$ & $3.77 \mathrm{E}+00$ & $1.17 \mathrm{E}-02$ & 0.00 & 232.43 & 34.47 \\
\hline 200 & $1.54 \mathrm{E}-02$ & $2.76 \mathrm{E}-03$ & $6.32 \mathrm{E}-02$ & $1.71 \mathrm{E}-02$ & $2.05 \mathrm{E}-02$ & $2.41 \mathrm{E}-03$ & $2.69 \mathrm{E}+00$ & $6.45 \mathrm{E}-03$ & $1.89 \mathrm{E}+02$ & $2.07 \mathrm{E}-01$ & 0.09 & 274.74 & 1.31 \\
\hline 300 & $1.52 \mathrm{E}-02$ & $1.16 \mathrm{E}-03$ & $7.47 \mathrm{E}-02$ & $1.16 \mathrm{E}-02$ & $2.26 \mathrm{E}-02$ & $3.07 \mathrm{E}-03$ & $5.25 \mathrm{E}+00$ & $1.56 \mathrm{E}-02$ & $3.65 \mathrm{E}+02$ & $4.62 \mathrm{E}-01$ & 0.27 & 275.17 & 0.86 \\
\hline 400 & $1.59 \mathrm{E}-02$ & $1.21 \mathrm{E}-03$ & $4.85 \mathrm{E}-02$ & $1.53 \mathrm{E}-02$ & $1.64 \mathrm{E}-02$ & $2.63 \mathrm{E}-03$ & $3.68 \mathrm{E}+00$ & $1.45 \mathrm{E}-02$ & $2.60 \mathrm{E}+02$ & $3.39 \mathrm{E}-01$ & 0.39 & 277.30 & 1.12 \\
\hline 600 & $4.65 \mathrm{E}-02$ & $2.53 \mathrm{E}-03$ & $1.13 \mathrm{E}-01$ & $1.62 \mathrm{E}-02$ & $2.43 \mathrm{E}-02$ & $2.72 \mathrm{E}-03$ & $4.28 \mathrm{E}+00$ & $1.26 \mathrm{E}-02$ & $3.09 \mathrm{E}+02$ & $3.66 \mathrm{E}-01$ & 0.53 & 276.63 & 1.04 \\
\hline 800 & $4.18 \mathrm{E}-02$ & $1.57 \mathrm{E}-03$ & $1.72 \mathrm{E}-01$ & $9.39 \mathrm{E}-03$ & $2.73 \mathrm{E}-02$ & $1.95 \mathrm{E}-03$ & $5.00 \mathrm{E}+00$ & $1.46 \mathrm{E}-02$ & $3.58 \mathrm{E}+02$ & $4.95 \mathrm{E}-01$ & 0.70 & 276.63 & 0.90 \\
\hline 1000 & 7.67E-02 & $1.49 \mathrm{E}-03$ & $5.75 \mathrm{E}-02$ & $1.30 \mathrm{E}-02$ & $1.97 \mathrm{E}-02$ & $1.67 \mathrm{E}-03$ & $2.09 \mathrm{E}+00$ & $6.30 \mathrm{E}-03$ & $1.67 \mathrm{E}+02$ & $1.66 \mathrm{E}-01$ & 0.77 & 276.37 & 1.14 \\
\hline 1200 & $6.83 \mathrm{E}-02$ & $1.49 \mathrm{E}-03$ & $2.23 \mathrm{E}-02$ & $8.97 \mathrm{E}-03$ & $1.75 \mathrm{E}-02$ & $1.34 \mathrm{E}-03$ & $1.47 \mathrm{E}+00$ & $2.64 \mathrm{E}-03$ & $1.22 \mathrm{E}+02$ & $1.25 \mathrm{E}-01$ & 0.82 & 277.11 & 1.24 \\
\hline 1400 & $6.54 \mathrm{E}-02$ & $1.23 \mathrm{E}-03$ & $3.01 \mathrm{E}-02$ & $1.06 \mathrm{E}-02$ & $1.67 \mathrm{E}-02$ & $1.29 \mathrm{E}-03$ & $8.71 \mathrm{E}-01$ & $7.71 \mathrm{E}-03$ & $7.94 \mathrm{E}+01$ & $6.70 \mathrm{E}-02$ & 0.85 & 276.34 & 2.76 \\
\hline 1600 & $6.83 \mathrm{E}-02$ & $1.65 \mathrm{E}-03$ & $4.00 \mathrm{E}-02$ & $1.09 \mathrm{E}-02$ & $1.65 \mathrm{E}-02$ & $1.37 \mathrm{E}-03$ & $6.99 \mathrm{E}-01$ & $4.58 \mathrm{E}-03$ & $6.84 \mathrm{E}+01$ & $4.91 \mathrm{E}-02$ & 0.87 & 275.98 & 3.10 \\
\hline 1800 & $3.92 \mathrm{E}-02$ & $2.47 \mathrm{E}-03$ & $3.68 \mathrm{E}-03$ & $1.10 \mathrm{E}-02$ & $7.96 \mathrm{E}-03$ & $2.03 \mathrm{E}-03$ & $7.79 \mathrm{E}-01$ & $5.74 \mathrm{E}-03$ & $6.45 \mathrm{E}+01$ & $4.85 \mathrm{E}-02$ & 0.90 & 272.32 & 3.95 \\
\hline 2000 & $5.62 \mathrm{E}-02$ & $2.73 \mathrm{E}-03$ & $1.38 \mathrm{E}-02$ & $1.51 \mathrm{E}-02$ & $1.39 \mathrm{E}-02$ & $1.84 \mathrm{E}-03$ & $5.83 \mathrm{E}-01$ & $3.35 \mathrm{E}-03$ & $5.69 \mathrm{E}+01$ & $4.21 \mathrm{E}-02$ & 0.92 & 276.40 & 5.35 \\
\hline 2400 & $9.63 \mathrm{E}-02$ & $3.51 \mathrm{E}-03$ & $1.84 \mathrm{E}-02$ & $1.18 \mathrm{E}-02$ & $2.21 \mathrm{E}-02$ & $1.66 \mathrm{E}-03$ & $8.20 \mathrm{E}-01$ & $4.31 \mathrm{E}-03$ & $8.47 \mathrm{E}+01$ & $3.62 \mathrm{E}-02$ & 0.94 & 274.71 & 4.89 \\
\hline 2800 & $1.02 \mathrm{E}-01$ & $2.25 \mathrm{E}-03$ & $4.07 \mathrm{E}-02$ & $1.39 \mathrm{E}-02$ & $2.55 \mathrm{E}-02$ & $1.72 \mathrm{E}-03$ & $5.28 \mathrm{E}-01$ & $3.61 \mathrm{E}-03$ & $6.74 \mathrm{E}+01$ & $1.06 \mathrm{E}-01$ & 0.96 & 281.51 & 5.05 \\
\hline 3200 & 3.69E-02 & $2.52 \mathrm{E}-03$ & $3.96 \mathrm{E}-02$ & $1.60 \mathrm{E}-02$ & $8.79 \mathrm{E}-03$ & $1.71 \mathrm{E}-03$ & $7.74 \mathrm{E}-01$ & $4.56 \mathrm{E}-03$ & $6.54 \mathrm{E}+01$ & $4.52 \mathrm{E}-02$ & 0.99 & 281.34 & 3.88 \\
\hline 4000 & $7.61 \mathrm{E}-02$ & $1.76 \mathrm{E}-03$ & $1.38 \mathrm{E}-02$ & $1.16 \mathrm{E}-02$ & 2.19E-02 & $2.25 \mathrm{E}-03$ & $3.77 \mathrm{E}-01$ & $4.33 \mathrm{E}-03$ & $4.82 \mathrm{E}+01$ & $4.60 \mathrm{E}-02$ & 1.00 & 273.66 & 5.91 \\
\hline $\mathrm{J}=$ & $2.40 \mathrm{E}-03$ & \pm & $2.16 \mathrm{E}-05$ & & & & & & & & & & \\
\hline
\end{tabular}


APPENDIX 1. (Cont.)

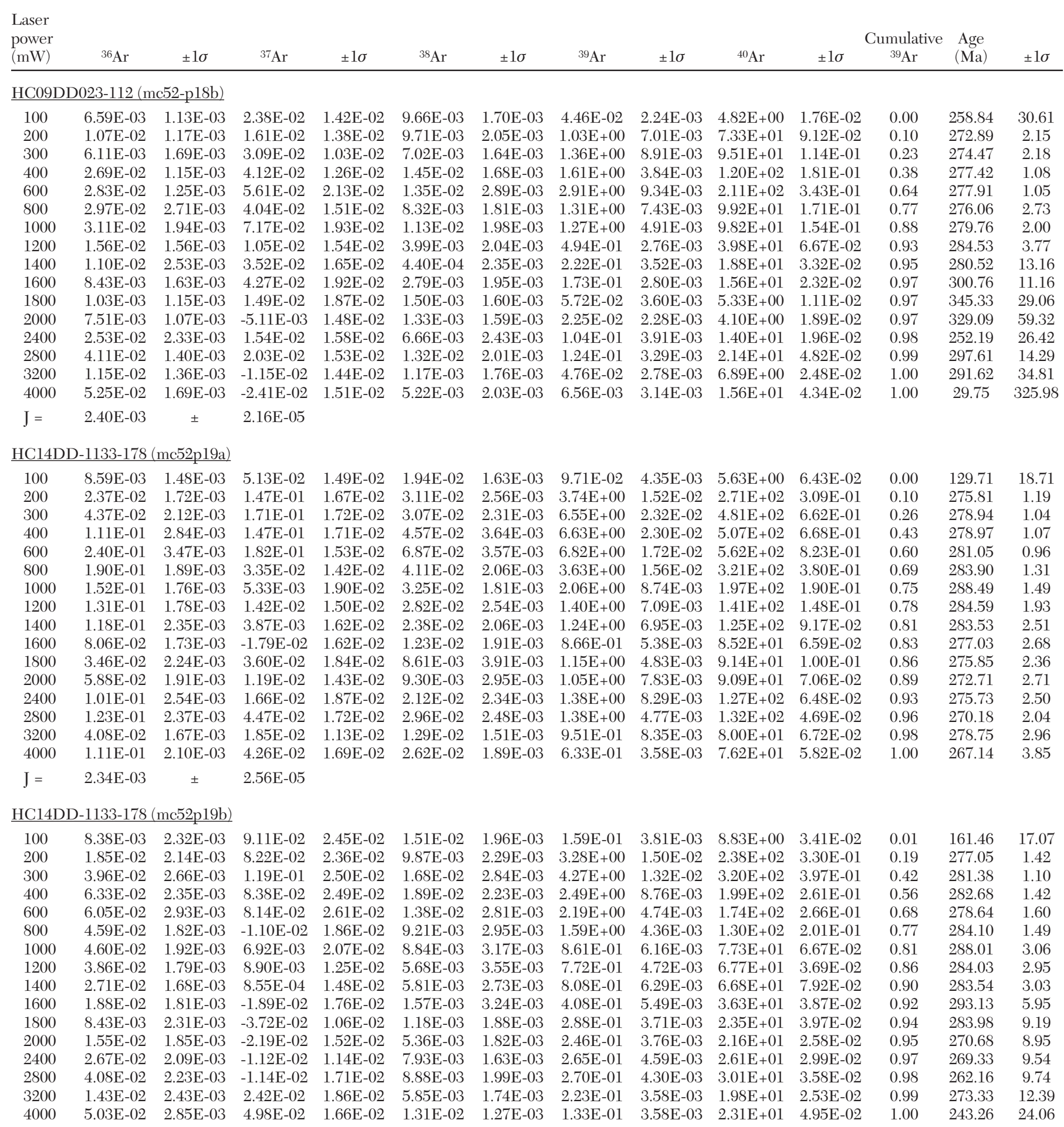

MCR024D-177 (mc52-sla)

$100 \quad 1.53 \mathrm{E}-03 \quad 1.63 \mathrm{E}-03 \quad 5.62 \mathrm{E}-02 \quad 1.36 \mathrm{E}-02 \quad 1.06 \mathrm{E}-02 \quad 1.93 \mathrm{E}-03 \quad 3.73 \mathrm{E}-02 \quad 3.67 \mathrm{E}-03 \quad 1.23 \mathrm{E}-02 \quad 3.96 \mathrm{E}-02$

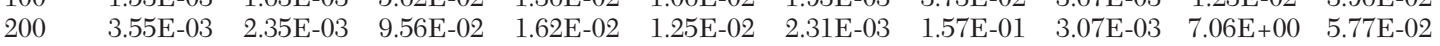

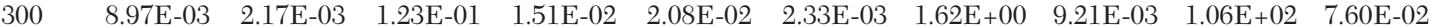

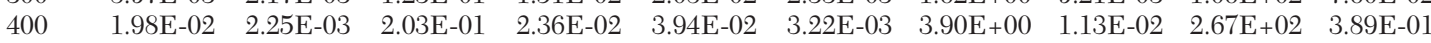
$600 \quad 3.49 \mathrm{E}-02 \quad 2.07 \mathrm{E}-03 \quad 2.46 \mathrm{E}-01 \quad 2.82 \mathrm{E}-02 \quad 4.35 \mathrm{E}-02 \quad 3.07 \mathrm{E}-03 \quad 3.69 \mathrm{E}+00 \quad 1.38 \mathrm{E}-02 \quad 2.57 \mathrm{E}+02 \quad 2.77 \mathrm{E}-01$

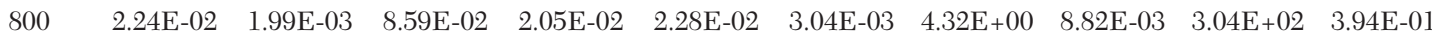
$1000 \quad 3.42 \mathrm{E}-02 \quad 2.44 \mathrm{E}-03 \quad 1.31 \mathrm{E}-01 \quad 1.87 \mathrm{E}-02 \quad 2.85 \mathrm{E}-02 \quad 3.28 \mathrm{E}-03 \quad 4.07 \mathrm{E}+00 \quad 1.99 \mathrm{E}-02 \quad 2.87 \mathrm{E}+02 \quad 4.32 \mathrm{E}-01$

$\begin{array}{lll}0.00 & -50.40 & 56.60 \\ 0.01 & 154.79 & 17.46 \\ 0.05 & 249.81 & 1.97 \\ 0.15 & 262.32 & 1.01 \\ 0.25 & 262.09 & 1.13 \\ 0.37 & 269.58 & 0.79 \\ 0.48 & 266.83 & 1.43\end{array}$


APPENDIX 1. (Cont.)

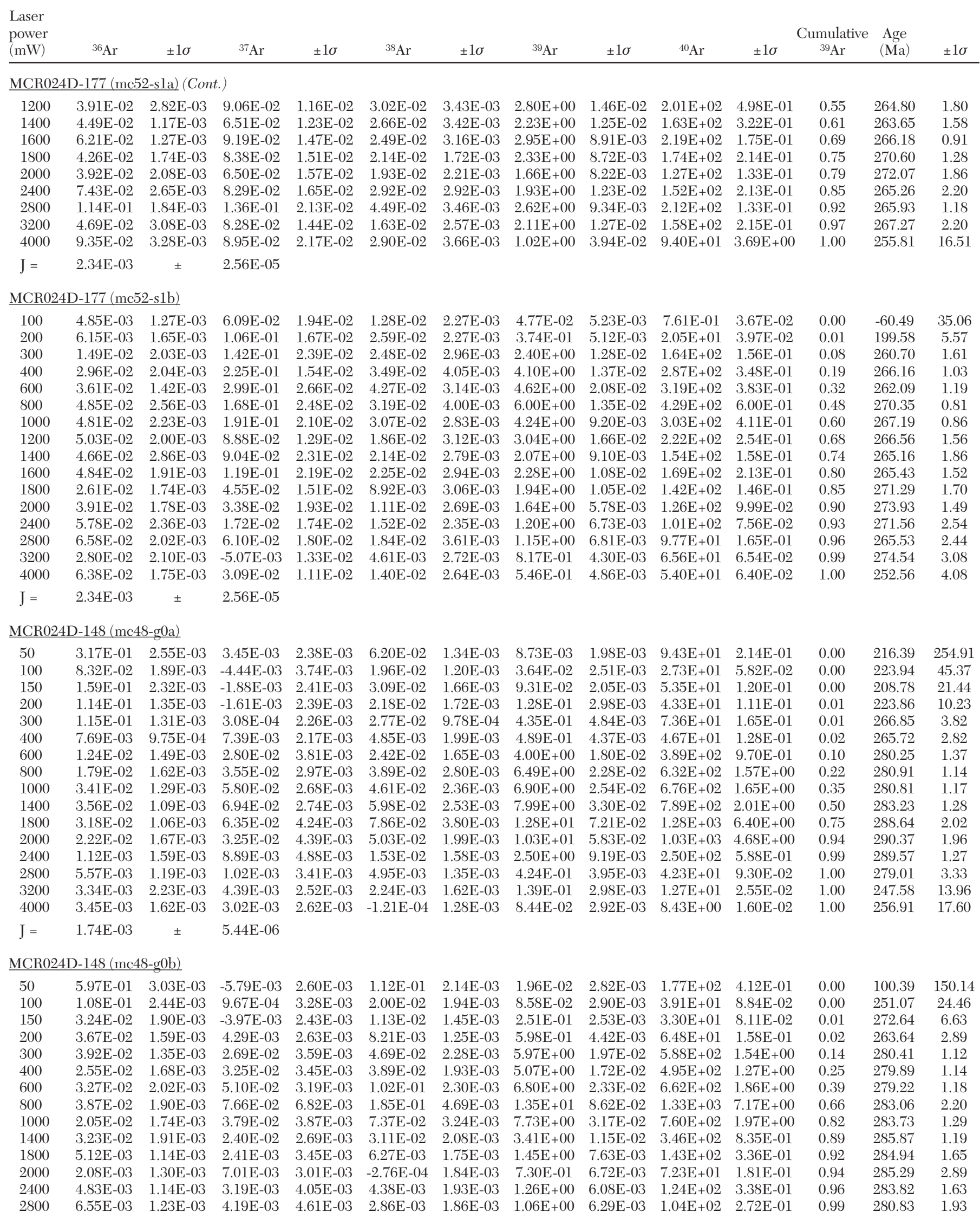


APPENDIX 1. (Cont.)

\begin{tabular}{|c|c|c|c|c|c|c|c|c|c|c|c|c|c|}
\hline $\begin{array}{l}\text { Laser } \\
\text { power } \\
(\mathrm{mW})\end{array}$ & ${ }^{36} \mathrm{Ar}$ & $\pm 1 \sigma$ & ${ }^{37} \mathrm{Ar}$ & $\pm 1 \sigma$ & ${ }^{38} \mathrm{Ar}$ & $\pm 1 \sigma$ & ${ }^{39} \mathrm{Ar}$ & $\pm 1 \sigma$ & ${ }^{40} \mathrm{Ar}$ & $\pm 1 \sigma$ & $\begin{array}{c}\text { Cumulative } \\
{ }^{39} \mathrm{Ar}\end{array}$ & $\begin{array}{l}\text { Age } \\
(\mathrm{Ma})\end{array}$ & $\pm 1 \sigma$ \\
\hline \multicolumn{14}{|c|}{ MCR024D-148 (mc48-g0b) (Cont.) } \\
\hline 3200 & $3.39 \mathrm{E}-03$ & $1.43 \mathrm{E}-03$ & $3.50 \mathrm{E}-03$ & $4.59 \mathrm{E}-03$ & 4.15E-04 & $1.13 \mathrm{E}-03$ & 5.37E-01 & $5.61 \mathrm{E}-03$ & $5.43 \mathrm{E}+01$ & $1.49 \mathrm{E}-01$ & 1.00 & 288.42 & 3.57 \\
\hline 4000 & $4.90 \mathrm{E}-03$ & $1.25 \mathrm{E}-03$ & 9.06E-04 & 4.13E-03 & $5.84 \mathrm{E}-04$ & $1.65 \mathrm{E}-03$ & 1.61E-01 & 2.63E-03 & $1.58 \mathrm{E}+01$ & $4.73 \mathrm{E}-02$ & 1.00 & 261.74 & 7.44 \\
\hline $\mathrm{J}=$ & $1.74 \mathrm{E}-03$ & \pm & $5.44 \mathrm{E}-06$ & & & & & & & & & & \\
\hline \multicolumn{14}{|c|}{$\underline{\mathrm{HC} 09 \mathrm{DD} 037-34 \text { (mc50-b17a) }}$} \\
\hline 100 & $1.62 \mathrm{E}-02$ & $1.70 \mathrm{E}-03$ & $1.79 \mathrm{E}-02$ & $8.03 \mathrm{E}-03$ & $3.36 \mathrm{E}-03$ & $2.27 \mathrm{E}-03$ & $1.10 \mathrm{E}-02$ & $2.10 \mathrm{E}-03$ & $4.61 \mathrm{E}+00$ & $1.76 \mathrm{E}-02$ & 0.00 & -52.76 & 147.39 \\
\hline 200 & 5.83E-02 & $1.59 \mathrm{E}-03$ & $-1.85 \mathrm{E}-05$ & $7.64 \mathrm{E}-03$ & $2.04 \mathrm{E}-02$ & $2.61 \mathrm{E}-03$ & 4.39E-02 & $3.44 \mathrm{E}-03$ & $2.07 \mathrm{E}+01$ & $5.24 \mathrm{E}-02$ & 0.01 & 233.76 & 34.28 \\
\hline 300 & $-8.00 \mathrm{E}-04$ & $1.25 \mathrm{E}-03$ & $9.42 \mathrm{E}-03$ & $6.63 \mathrm{E}-03$ & 1.70E-03 & 2.33E-03 & 1.18E-02 & $3.58 \mathrm{E}-03$ & 9.73E-01 & $7.75 \mathrm{E}-03$ & 0.01 & 295.87 & 117.32 \\
\hline 400 & $-5.79 \mathrm{E}-04$ & $1.91 \mathrm{E}-03$ & $5.75 \mathrm{E}-03$ & $7.28 \mathrm{E}-03$ & 9.36E-04 & $2.34 \mathrm{E}-03$ & 4.01E-03 & $1.46 \mathrm{E}-03$ & 7.22E-02 & $1.04 \mathrm{E}-02$ & 0.01 & 180.94 & 404.44 \\
\hline 600 & 1.63E-03 & $1.07 \mathrm{E}-03$ & $1.23 \mathrm{E}-02$ & $7.95 \mathrm{E}-03$ & $6.27 \mathrm{E}-03$ & $2.55 \mathrm{E}-03$ & 4.59E-02 & $2.81 \mathrm{E}-03$ & $4.47 \mathrm{E}+00$ & $1.64 \mathrm{E}-02$ & 0.02 & 253.97 & 23.76 \\
\hline 800 & $9.75 \mathrm{E}-04$ & $1.97 \mathrm{E}-03$ & $2.64 \mathrm{E}-03$ & $9.69 \mathrm{E}-03$ & $3.24 \mathrm{E}-03$ & $2.40 \mathrm{E}-03$ & 2.18E-02 & $2.89 \mathrm{E}-03$ & $1.85 \mathrm{E}+00$ & $9.18 \mathrm{E}-03$ & 0.02 & 212.34 & 79.24 \\
\hline 1000 & $-9.73 \mathrm{E}-04$ & $1.36 \mathrm{E}-03$ & $2.80 \mathrm{E}-03$ & $1.01 \mathrm{E}-02$ & $3.12 \mathrm{E}-03$ & $2.05 \mathrm{E}-03$ & 4.96E-02 & $2.26 \mathrm{E}-03$ & $4.60 \mathrm{E}+00$ & $1.55 \mathrm{E}-02$ & 0.03 & 285.40 & 24.85 \\
\hline 1200 & $1.62 \mathrm{E}-03$ & $1.53 \mathrm{E}-03$ & $6.65 \mathrm{E}-03$ & $1.09 \mathrm{E}-02$ & 4.03E-03 & $2.00 \mathrm{E}-03$ & 7.68E-02 & $1.99 \mathrm{E}-03$ & $7.42 \mathrm{E}+00$ & $1.88 \mathrm{E}-02$ & 0.04 & 263.09 & 17.23 \\
\hline 1400 & $1.44 \mathrm{E}-04$ & $1.91 \mathrm{E}-03$ & $2.53 \mathrm{E}-03$ & $9.65 \mathrm{E}-03$ & $6.26 \mathrm{E}-03$ & $1.80 \mathrm{E}-03$ & 8.43E-02 & $3.56 \mathrm{E}-03$ & $7.06 \mathrm{E}+00$ & 2.19E-02 & 0.06 & 244.06 & 20.74 \\
\hline 1600 & $7.85 \mathrm{E}-04$ & $9.51 \mathrm{E}-04$ & 4.46E-03 & $8.50 \mathrm{E}-03$ & $1.27 \mathrm{E}-02$ & $2.01 \mathrm{E}-03$ & $3.54 \mathrm{E}-01$ & $4.16 \mathrm{E}-03$ & $3.37 \mathrm{E}+01$ & $5.90 \mathrm{E}-02$ & 0.11 & 274.08 & 3.70 \\
\hline 1800 & $2.82 \mathrm{E}-03$ & $1.87 \mathrm{E}-03$ & $1.18 \mathrm{E}-02$ & $9.02 \mathrm{E}-03$ & 2.01E-02 & $1.70 \mathrm{E}-03$ & 6.82E-01 & $2.61 \mathrm{E}-03$ & $6.41 \mathrm{E}+01$ & $1.21 \mathrm{E}-01$ & 0.22 & 269.40 & 2.43 \\
\hline 2000 & $2.98 \mathrm{E}-03$ & $2.25 \mathrm{E}-03$ & $1.24 \mathrm{E}-03$ & $9.93 \mathrm{E}-03$ & 1.92E-02 & $1.16 \mathrm{E}-03$ & $7.45 \mathrm{E}-01$ & $5.24 \mathrm{E}-03$ & $6.99 \mathrm{E}+01$ & $1.33 \mathrm{E}-01$ & 0.34 & 269.53 & 3.02 \\
\hline 2400 & $2.24 \mathrm{E}-03$ & $1.75 \mathrm{E}-03$ & $1.50 \mathrm{E}-02$ & $1.01 \mathrm{E}-02$ & 3.75E-02 & $1.86 \mathrm{E}-03$ & $1.04 \mathrm{E}+00$ & $5.25 \mathrm{E}-03$ & $9.80 \mathrm{E}+01$ & $1.77 \mathrm{E}-01$ & 0.51 & 271.74 & 1.90 \\
\hline 2800 & 3.39E-03 & $1.91 \mathrm{E}-03$ & 1.61E-02 & $9.26 \mathrm{E}-03$ & 7.22E-02 & $1.70 \mathrm{E}-03$ & $1.84 \mathrm{E}+00$ & 3.63E-03 & $1.77 \mathrm{E}+02$ & $2.27 \mathrm{E}-01$ & 0.80 & 277.84 & 1.02 \\
\hline 3200 & $-4.47 \mathrm{E}-04$ & $1.56 \mathrm{E}-03$ & 3.87E-03 & $8.22 \mathrm{E}-03$ & 3.76E-02 & $1.84 \mathrm{E}-03$ & $1.12 \mathrm{E}+00$ & $2.36 \mathrm{E}-03$ & $1.10 \mathrm{E}+02$ & $1.78 \mathrm{E}-01$ & 0.98 & 283.81 & 1.31 \\
\hline 4000 & $-2.56 \mathrm{E}-03$ & 3.31E-03 & $-5.09 \mathrm{E}-04$ & $8.40 \mathrm{E}-03$ & $5.60 \mathrm{E}-03$ & $1.48 \mathrm{E}-03$ & 1.18E-01 & $3.84 \mathrm{E}-03$ & $1.11 \mathrm{E}+01$ & $3.07 \mathrm{E}-02$ & 1.00 & 291.75 & 23.87 \\
\hline $\mathrm{J}=$ & $1.74 \mathrm{E}-03$ & \pm & $1.13 \mathrm{E}-05$ & & & & & & & & & & \\
\hline \multicolumn{14}{|c|}{ HC09DD037-34 (mc50-b17b) } \\
\hline 100 & $1.39 \mathrm{E}-04$ & $2.23 \mathrm{E}-03$ & 7.46E-03 & $6.21 \mathrm{E}-03$ & 5.48E-04 & $1.39 \mathrm{E}-03$ & $2.09 \mathrm{E}-03$ & $2.06 \mathrm{E}-03$ & $3.51 \mathrm{E}-01$ & $7.62 \mathrm{E}-03$ & 0.00 & 414.11 & 866.10 \\
\hline 200 & $7.06 \mathrm{E}-03$ & $1.57 \mathrm{E}-03$ & $-3.69 \mathrm{E}-04$ & $4.02 \mathrm{E}-03$ & 7.48E-03 & $1.26 \mathrm{E}-03$ & 2.69E-02 & 2.19E-03 & $4.74 \mathrm{E}+00$ & $2.02 \mathrm{E}-02$ & 0.01 & 285.81 & 51.07 \\
\hline 300 & $1.35 \mathrm{E}-03$ & $1.74 \mathrm{E}-03$ & $1.21 \mathrm{E}-02$ & $4.94 \mathrm{E}-03$ & $6.72 \mathrm{E}-03$ & $1.08 \mathrm{E}-03$ & $3.75 \mathrm{E}-02$ & $2.00 \mathrm{E}-03$ & $3.24 \mathrm{E}+00$ & 8.92E-03 & 0.02 & 223.32 & 39.52 \\
\hline 400 & $-8.88 \mathrm{E}-04$ & $1.44 \mathrm{E}-03$ & $-1.06 \mathrm{E}-03$ & $6.28 \mathrm{E}-03$ & $1.15 \mathrm{E}-03$ & $1.03 \mathrm{E}-03$ & 2.23E-02 & $1.56 \mathrm{E}-03$ & $1.88 \mathrm{E}+00$ & $1.52 \mathrm{E}-02$ & 0.03 & 278.55 & 54.48 \\
\hline 600 & $-5.46 \mathrm{E}-04$ & $1.32 \mathrm{E}-03$ & 8.92E-03 & $5.65 \mathrm{E}-03$ & 3.59E-03 & $1.80 \mathrm{E}-03$ & $1.06 \mathrm{E}-01$ & $1.71 \mathrm{E}-03$ & $1.02 \mathrm{E}+01$ & $2.17 \mathrm{E}-02$ & 0.06 & 282.19 & 10.72 \\
\hline 800 & $2.49 \mathrm{E}-03$ & $1.62 \mathrm{E}-03$ & 2.40E-02 & $7.60 \mathrm{E}-03$ & 2.68E-02 & $2.05 \mathrm{E}-03$ & $4.54 \mathrm{E}-01$ & $4.07 \mathrm{E}-03$ & $4.55 \mathrm{E}+01$ & $6.79 \mathrm{E}-02$ & 0.20 & 285.16 & 3.70 \\
\hline 1000 & $6.35 \mathrm{E}-04$ & $1.78 \mathrm{E}-03$ & 2.84E-02 & $1.02 \mathrm{E}-02$ & 2.36E-02 & $2.84 \mathrm{E}-03$ & $5.40 \mathrm{E}-01$ & $2.64 \mathrm{E}-03$ & $5.36 \mathrm{E}+01$ & $1.05 \mathrm{E}-01$ & 0.36 & 285.91 & 2.95 \\
\hline 1200 & $9.18 \mathrm{E}-04$ & $1.74 \mathrm{E}-03$ & 1.59E-02 & 7.83E-03 & $4.20 \mathrm{E}-02$ & $2.61 \mathrm{E}-03$ & 7.08E-01 & $4.90 \mathrm{E}-03$ & $6.95 \mathrm{E}+01$ & $1.66 \mathrm{E}-01$ & 0.58 & 283.45 & 2.74 \\
\hline 1400 & $5.09 \mathrm{E}-04$ & $1.57 \mathrm{E}-03$ & 2.51E-02 & $8.92 \mathrm{E}-03$ & 5.99E-02 & 3.37E-03 & $1.10 \mathrm{E}+00$ & 3.38E-03 & $1.08 \mathrm{E}+02$ & $1.35 \mathrm{E}-01$ & 0.92 & 283.96 & 1.42 \\
\hline 1600 & $5.06 \mathrm{E}-04$ & $1.78 \mathrm{E}-03$ & $1.74 \mathrm{E}-02$ & $9.00 \mathrm{E}-03$ & 7.78E-03 & $2.03 \mathrm{E}-03$ & 2.23E-01 & 3.69E-03 & $2.23 \mathrm{E}+01$ & $3.79 \mathrm{E}-02$ & 0.98 & 286.93 & 7.68 \\
\hline 1800 & $-2.44 \mathrm{E}-03$ & $2.20 \mathrm{E}-03$ & $4.46 \mathrm{E}-03$ & 8.96E-03 & $-2.37 \mathrm{E}-04$ & $2.61 \mathrm{E}-03$ & 8.85E-03 & $3.13 \mathrm{E}-03$ & $9.47 \mathrm{E}-01$ & $8.26 \mathrm{E}-03$ & 0.99 & 511.02 & 233.91 \\
\hline 2000 & $-2.23 \mathrm{E}-03$ & 2.16E-03 & $-1.35 \mathrm{E}-03$ & $9.70 \mathrm{E}-03$ & $-1.60 \mathrm{E}-04$ & $1.42 \mathrm{E}-03$ & 2.59E-03 & $2.92 \mathrm{E}-03$ & $2.37 \mathrm{E}-01$ & $1.18 \mathrm{E}-02$ & 0.99 & 850.83 & 905.37 \\
\hline 2400 & $-6.62 \mathrm{E}-04$ & $2.04 \mathrm{E}-03$ & $-2.29 \mathrm{E}-03$ & $8.94 \mathrm{E}-03$ & 1.11E-03 & $1.76 \mathrm{E}-03$ & 1.12E-02 & 2.61E-03 & $4.38 \mathrm{E}-01$ & $9.88 \mathrm{E}-03$ & 0.99 & 169.79 & 158.61 \\
\hline 2800 & $-1.24 \mathrm{E}-03$ & $2.10 \mathrm{E}-03$ & 9.90E-03 & $1.07 \mathrm{E}-02$ & $2.51 \mathrm{E}-03$ & $1.50 \mathrm{E}-03$ & 1.53E-02 & $2.78 \mathrm{E}-03$ & $1.60 \mathrm{E}+00$ & $1.82 \mathrm{E}-02$ & 1.00 & 365.58 & 120.51 \\
\hline 3200 & $3.41 \mathrm{E}-03$ & $3.00 \mathrm{E}-03$ & $-2.04 \mathrm{E}-03$ & 4.93E-03 & 1.10E-03 & $1.80 \mathrm{E}-03$ & 1.49E-02 & $2.60 \mathrm{E}-03$ & $1.51 \mathrm{E}+00$ & $1.36 \mathrm{E}-02$ & 1.00 & 102.12 & 177.15 \\
\hline 4000 & $3.14 \mathrm{E}-03$ & $2.43 \mathrm{E}-03$ & $3.37 \mathrm{E}-03$ & $5.80 \mathrm{E}-03$ & $9.75 \mathrm{E}-04$ & $1.47 \mathrm{E}-03$ & $-1.15 \mathrm{E}-03$ & $2.76 \mathrm{E}-03$ & $5.09 \mathrm{E}-01$ & $1.05 \mathrm{E}-02$ & 1.00 & 881.75 & 2052.02 \\
\hline $\mathrm{J}=$ & $1.74 \mathrm{E}-03$ & \pm & 1.13E-05 & & & & & & & & & & \\
\hline
\end{tabular}


APPENDIX 1. (Cont.)

Age, $\mathrm{Ca} / \mathrm{K}$, and $\mathrm{Cl} / \mathrm{K}$ Spectra for Alunite Samples from Mt. Carlton
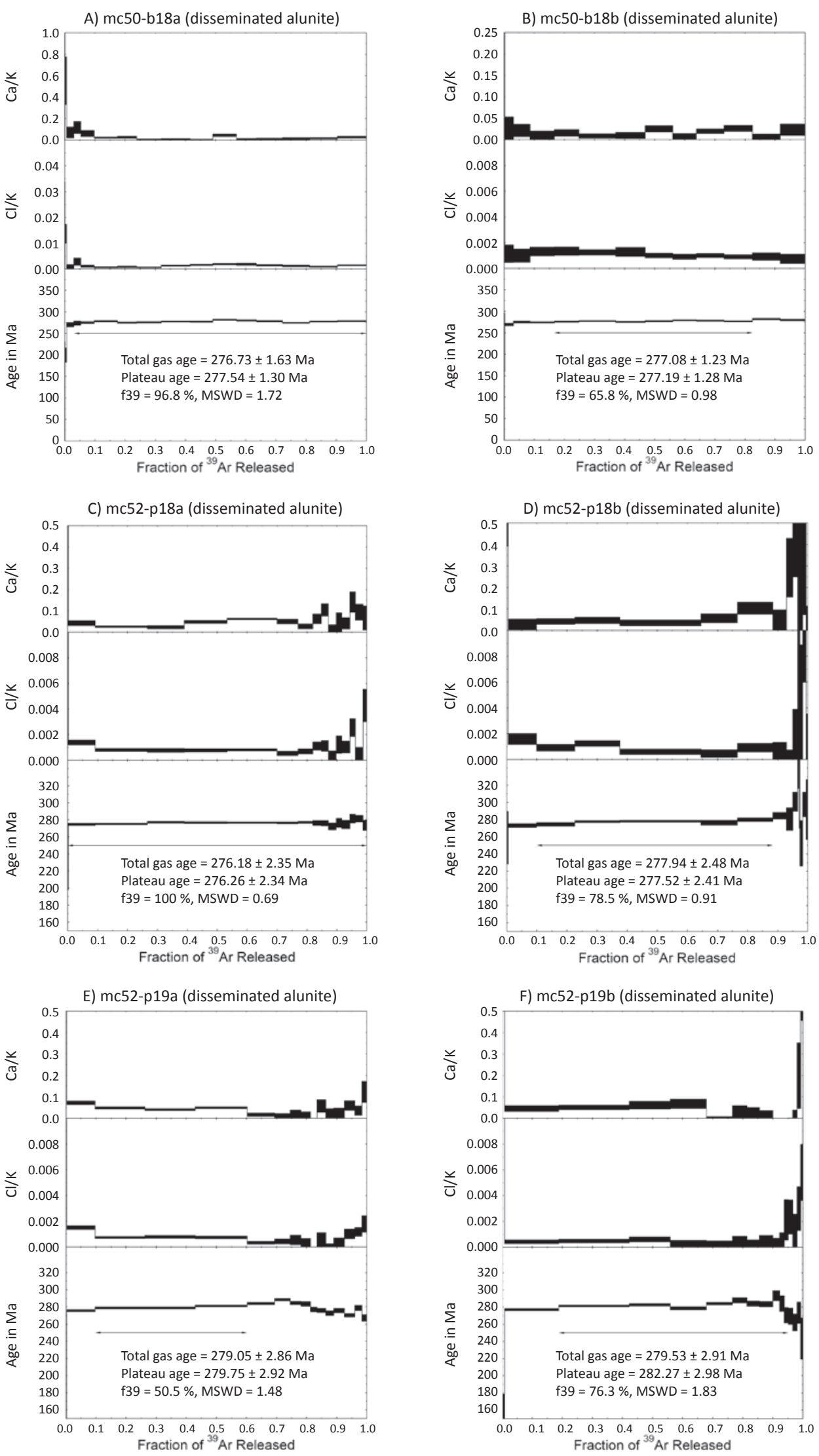
APPENDIX 1. (Cont.)

G) mc52-s1a (disseminated alunite)
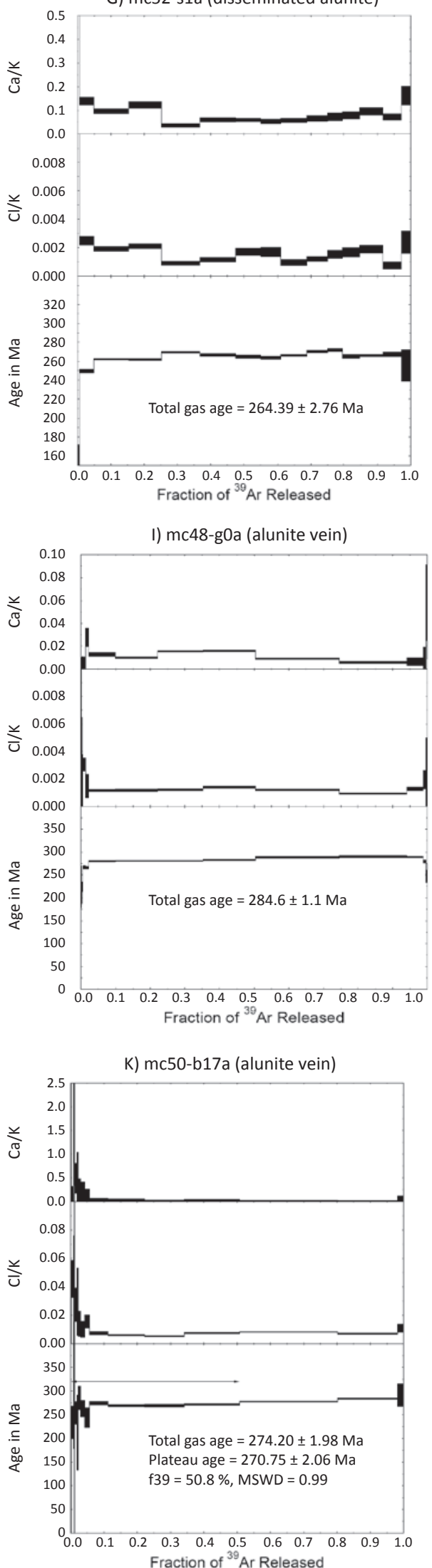

H) mc52-s1b (disseminated alunite)
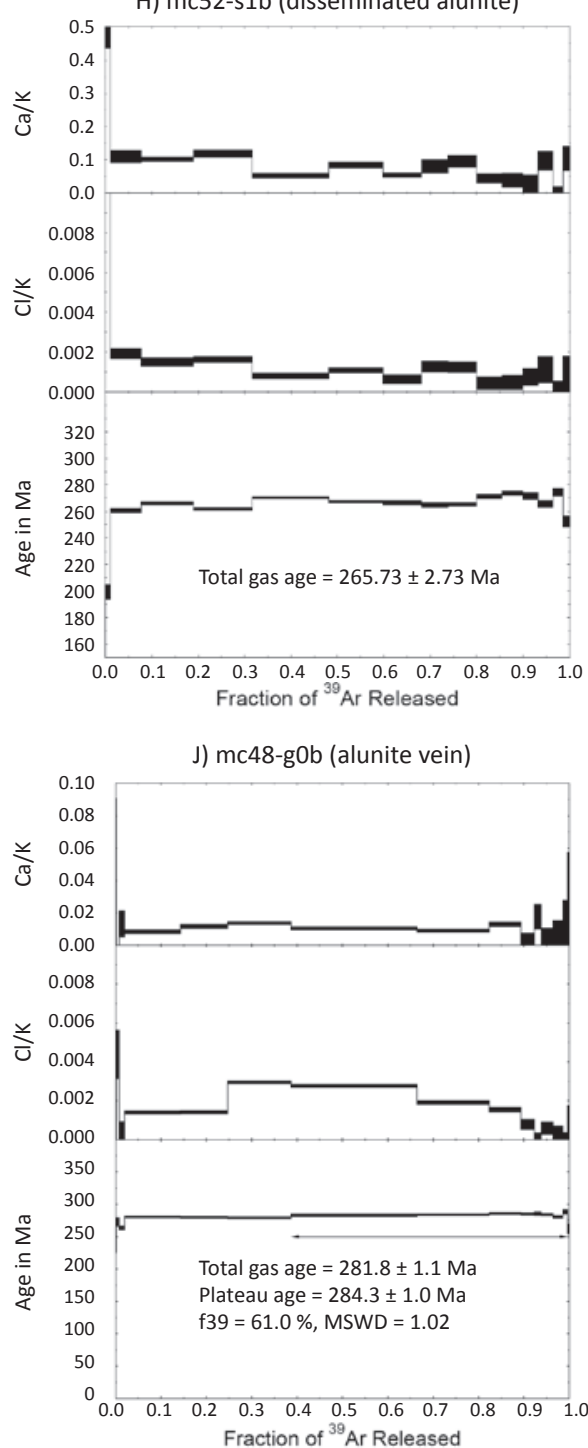

L) mc50-b17b (alunite vein)

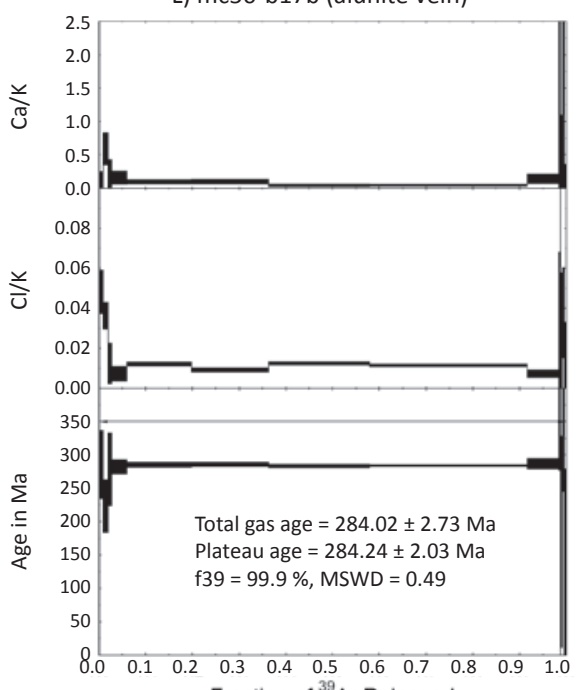


Fredrik Sahlström is a Ph.D. student at the Economic Geology Research Centre at James Cook University, Australia. He previously earned his B.Sc. and M.Sc. degrees from Uppsala University, Sweden, and has diverse interests in volcanology, high-temperature geochemistry, mineralogy. and ore deposits. His research has primarily focused on the genesis of the "Bastnäs-type" rare earth element deposits in central Sweden and, more recently, on various aspects of the Mt. Carlton high-sulfidation epithermal deposit in northeastern Australia. 

Downloaded from https://pubs.geoscienceworld.org/segweb/economicgeology/article-pdf/113/8/1733/4638330/1733-1767.pdf 